\title{
Leidimara Pelisson
}

\section{Produção de biodiesel por meio de fluidos pressurizados e sua caracterização utilizando Cromatografia Gasosa de Alta Resolução (HRGC)}

Tese apresentada ao Instituto de Química de São Carlos, Universidade de São Paulo para obtenção do título de Doutora em Ciências

Área de concentração: Química Analítica e inorgânica

Orientador: Prof. Dr. Fernando M. Lanças

Versão revisada

São Carlos

2013 


\section{Agradecimentos}

Agradeço ao meu grandioso Deus por tudo o que ele fez e faz por mim. Por ter me dado a oportunidade de viver e condições favoráveis para realização desse sonho.

Aos meus pais Mario e Marlene pelo apoio e compreensão por minha ausência em datas e momentos especiais, além do incentivo dado durante toda esta caminhada.

Ao professor Dr. Fernando Mauro Lanças, pela oportunidade, pela orientação, incentivos, ensinamentos, e principalmente, pela confiança e apoio nos momentos mais essenciais, sem os quais este trabalho não teria sido desenvolvido.

À minha irmã Kátia, apoiando-me em todas as horas e que tanto foi alívio nas horas difíceis.

Ao meu namorado Raphael, apoiando-me, com grande companheirismo na última etapa desse meu trabalho.

Ao professor Dr. Álvaro José dos Santos Neto pela amizade e apoio. Agradeço pela sua paciência despendida no convívio diário e pelas incansáveis discussões acadêmicas.

Aos professores Drs. Wagner Luiz Polito e Eduardo Bessa Azevedo pelas discussões durante o exame de qualificação.

À Elaine A. A. F. Gobato pelo incentivo e amizade.

Às minhas amigas Michele Lima e Luciana Tinoz por trazerem momentos de alegria e descontração.

À Silvia de Guzzi Plepis e Andréia C. C. de Moraes da secretaria de Pós-graduação, pela solicitude, e pelo empenho no desembargo de todos os meus processos.

Às funcionárias da biblioteca do IQSC, principalmente à Bernadete L. C. B. Figueiredo, pelo auxílio nas buscas e solicitações bibliográficas.

Aos funcionários da oficina mecânica, especialmente ao Alex Sandro Contadori, pela execução de todos os serviços e construções solicitadas.

Ao IQSC, pelo apoio institucional. 
À CAPES pelo apoio financeiro e concessão da bolsa.

Enfim, agradeço a todos que mesmo anonimamente, colaboraram para que eu pudesse chegar até aqui.

"Não é o desafio com que nos deparamos que determina quem somos e o que estamos nos tornando, mas a maneira com que respondemos ao desafio." 


\section{Resumo}

O esgotamento das reservas de petróleo, bem como o impacto ambiental que o seu processamento provoca, tem induzido a busca por fontes alternativas de energia para substituir os fósseis de petróleo como combustível automotivo. No Brasil, o crescimento do agronegócio e o consequente uso dos seus produtos e resíduos de fontes vegetais, favoreceram incríveis descobertas tais como matérias-primas para biocombustíveis, incluindo bioetanol derivado de cana de açúcar e biodiesel de óleos vegetais. Neste sentido, o biodiesel tem recebido bastante destaque nos últimos anos. O objetivo do presente estudo foi a para produção de biodiesel de óleo de soja empregando metanol ou etanol como álcoois pressurizados, além da análise da influencia da adição de água nas melhores condições alcançadas. Para tal, uma unidade experimental de bancada foi construída. Para investigação das variáveis que influenciam o rendimento das reações no sistema estudado, um planejamento fatorial $2^{3}$ foi adotado, no qual foram investigados os efeitos da temperatura (180 e $300^{\circ} \mathrm{C}$ ), do tempo de residência (10 minutos e 1 hora), da razão molar óleo:etanol (1:10 e 1:50), e da concentração de água ( 0 a 10\% massa em relação ao óleo) sobre a conversão em ésteres da reação, que foi monitorada por cromatografia gasosa de alta resolução. Observou-se que a temperatura tem forte influência na conversão em ésteres da reação, com os melhores resultados para metanol ou etanol (95\% de conversão) tendo sido obtidos na temperatura de $300^{\circ} \mathrm{C}$. A adição de agua (2,5 e 5,0\% em relação ao óleo) ocasionou um leve aumento na conversão (98\%) para ambos metanol e etanol. Então, conclui-se então, que condições similares no rendimento do biodiesel de óleo de soja em reator batelada foi obtido utilizando metanol ou etanol pressurizados em condições supercriticas. Este trabalho também propõe uma nova metodologia para análise de acilgliceróis.

Palavras-chave: Biodiesel, fluido supercrítical, etanol 


\begin{abstract}
The depletion of petroleum reserves coupled with the environmental impact caused by the form of its industrial processing lead a frantic search for alternative energy sources to replace fossil petroleum as automotive fuel. In Brazil, the growth of agribusiness and the consequent use of its products and resides of vegetable sources, brought exciting discoveries such as feedstock biofuels, including bioethanol derived from sugar cane and biodiesel from vegetable oil. In this since, the biodiesel has been receiving singular attention at last years. The objective of this present study was producing biodiesel from soybean oil using methanol or ethanol as alcohol pressurized beyond the analysis of the influence of added water under optimum conditions achieved. For such, an experimental unity was built. To investigate the variables influencing in the yield of the reaction in the system studied, an experimental planning using $2^{3}$ arranged was adopted, in which was investigated the effects of temperature $\left(220\right.$ and $\left.300^{\circ} \mathrm{C}\right)$ residence time (10 minutes and 1 hour) and molar ration (oil/alcohol) (1:10 and 1:50). After, the addition of water to the system (0 to $10 \%$ in relation to oil) was also evaluated on the conversion to esters, which was monitored by high resolution gas chromatography. It was observed that temperature has a strong influence on the conversion of esters with the best results for methanol or ethanol (95\% conversion) were obtained at a temperature of $300^{\circ} \mathrm{C}$. Addition of water (2,5 and $5,0 \%$ in relation to oil) caused a slight increase in conversion (98\%) for both methanol and ethanol. Then was concluded that similar results in the yields of biodiesel from soybean oil in batch reactor was obtained from both methanol or ethanol pressurized as supercritical conditions. This work proposes a new methodology for acylglycerols analysis.
\end{abstract}

Keywords: biodiesel, supercritical fluid, ethanol 


\section{Lista de Figuras}

Figura 1.1 - Diagrama genérico de estados de uma substância pura................................28

Figura 1.2 - Diagrama indicando o estado gasoso, líquido e o supecrítico de uma

substância.

Figura 1.3 - Diagrama esquemático do aparato experimental prévio desenvolvido. ............. 35

Figura 1.4 - Diagrama esquemático do aparato experimental desenvolvido após modificações.

Figura 1.5 - Desenho esquemático do anel de cobre utilizado para vedação da cela de reação.

Figura 1.6 - Desenho esquemático da cela de reação completa com visualização de corte da cela de reação e cela de reação inteira

Figura 2.1- Esquema das reações envolvidas na transesterificação de triglicerídeos, onde $R$ é uma cadeia hidrocarbônica.

Figura 2.2 - Esquema das estruturas das moléculas do glicerol, ácido graxo,

monoglicerídeo, diglicerídeo e triglicerídeo, onde $\mathrm{R}$ é uma cadeia hidrocarbônica.

Figura 2.3 - Figura da estrutura da molécula da triricinoleína (triglicerídeo presente no óleo de mamona).

Figura 2.4 -Mecanismo de reação de transesterificação alcalina de triglicerídeos com metanol, onde $\mathrm{B}$ é uma base e $\mathrm{R}$ é uma cadeia hidrocarbônica.

Figura 2.5 - Reação secundária durante a transesterificação utilizando hidróxido de potássio.

Figura 2.6 - Mecanismo de reação de transesterificação ácida de triglicerídeos com metanol.

Figura 2.7 - Proposta de mecanismo de reação de transesterificação de triglicerídeos em metanol supercrítico.

Figura 2.8 - Diagrama de pareto obtido do planejamento $2^{3}$ para as reações de produção de biodiesel de óleo de soja com metanol pressurizado.

Figura 2.9 - Gráfico dos valores observados e dos valores obtidos do planejamento $2^{3}$ para o rendimento das reações de produção de biodiesel com metanol pressurizado.

Figura 2.10 - Cubo que demonstra o planejamento $2^{3}$ para a conversão das reações de produção de biodiesel com metanol pressurizado.

Figura 2.11 - Diagrama de pareto obtido do planejamento $2^{3}$ para as reações de produção de biodiesel de óleo de soja com etanol pressurizado.

2.12 - Gráfico dos valores observados e dos valores obtidos do planejamento $2^{3}$ para a concersão das reações de produção de biodiesel com etanol pressurizado.

Figura 2.13 - Cubo que demonstra o planejamento $2^{3}$ para a conversão das reações de produção de biodiesel com etanol pressurizado.

Figura 2.14 - Efeito do teor de água sobre a conversão em ésteres metílicos: comparação entre metanol supercrítico $(\circ)$ e catálise homogênea básica $(\boldsymbol{\square})$ e ácida $(\mathbf{A})$...................... 76

Figura 2.15 - Figura demonstrando a hidrólise de triglicerídeos....................................... 77

Figura 2.16 - Figura da reação de esterificação de um ácido graxo com metanol...............77 Figura 3.1 - Cromatograma de mistura $\left(0,5 \mathrm{mg} \mathrm{mL}^{-1}\right.$ em n-hexano) contendo monoglicerídeos (MAGs), diglicerídeos (DAGs) e triglicerídeos (TAGs). Na figura é indicado também a banda de tempo de retenção dos ésteres metílicos de ácidos graxos (FAMEs). $T_{50}$ são os triglicerídeos com 50 átomos de carbono (excluindo os carbonos da cadeia de glicerol), $T_{52}$ são os triglicerídeos com 52 átomos de carbono na cadeia, $T_{54}$ triglicerídeos 
com 54 átomos de carbono na cadeia e $T_{56}$ triglicerídeos com 56 átomos de carbono na cadeia......

Figura 3.2 - Cromatograma do biodiesel metílico de soja.............................................97

Figura 3.3 - Cromatograma do biodiesel de soja fortificado utilizando a programação de temperatura de forno da tabela 3.5. . . 


\section{Lista de Tabelas}

Tabela 1.1 - Propriedades físico-químicas associadas a diferentes estados de uma substância.

Tabela 1.2 - Parâmetros físico - químicos de alguns compostos utilizados em seus estados supercríticos. ${ }^{10}$

Tabela 1.3 - Propriedades físico-químicas do metanol em condições normais e em condições supercríticas

Tabela 2.1 - Programação de temperatura do forno para caracterização e quantificação do óleo de soja ............................................................................54

Tabela 2.2 - Composição média do óleo de soja comercial.

Tabela 2.3 - Níveis para o planejamento fatorial $2^{3}$. Processo de produção de biodiesel a partir do óleo de soja e metanol ou etanol em reator supercrítico .56 Tabela 2.4 - Matriz de planejamento $2^{3}$ para as reações de biodiesel a partir do óleo de soja e metanol ou etanol em reator para fluidos pressurizados

Tabela 2.5 - Programação de temperatura do forno para caracterização e quantificação dos biodieseis etílicos e metílicos do óleo de soja

Tabela 2.6 - Propriedades termo-físicas dos reagentes utilizados para a síntese do biodiesel com álcool supercrítico em batelada sem a presença de catalisador. 65

Tabela 2.7 - Conversões obtidas no planejamento $2^{3}$ das reações de transesterificação do óleo de soja em metanol pressurizado utilizando os níveis apresentada na Tabela 2.3.

Tabela 2.8 - Conversões obtidas no planejamento $2^{3}$ das reações de transesterificação do óleo de soja em etanol pressurizado utilizando os níveis apresentada na Tabela 2.3

Tabela 2.9 - Estimativa dos efeitos das variáveis e suas interações sobre o rendimento da reação de produção de biodiesel de óleo de soja obtidos do planejamento $2^{3}$ com metanol pressurizado e seus respectivos limites de confiança.

Tabela 2.10 - Estimativa dos efeitos das variáveis e suas interações sobre a conversão da reação de produção de biodiesel de óleo de soja obtidos do planejamento $2^{3}$ com etanol pressurizado e seus respectivos limites de confiança.. 71 Tabela 3.1 - Descrição dos vários parâmetros empregados atualmente para especificação do biodiesel. ${ }^{3}$

Tabela 3.2 - Programação de temperatura do forno da coluna para análises do biodiesel produzido. 92

Tabela 3.3 - Tabela de soluções estoque.

Tabela 3.4 - Tabela de diluições das soluções padrão da curva analítica para quantificação de mono, di e triglicerídeos.

Tabela 3.5 - Tabela de programação de temperatura otimizada para análise de ésteres, mono, di e triglicerídeos em amostras de biodiesel. 


\section{Lista de Abreviações e Siglas}

Agência Nacional de Petróleo Gás Natura e Biocombustíveis (ANP)

American Society of Testing and Materials (ASTM)

Associação Brasileira de Normas Técnicas (ABNT)

Banco Nacional de Desenvolvimento Econômico e Social (BNDES)

Comitê Europeu de Normalização (CEN)

Conselho Nacional Americano de Biodiesel (CNAB)

Comissão Executiva Interministerial (CEIB)

Contribuição para Financiamento da Segurança Social (COFINS)

Cromatografia a Gás em Altas Temperaturas (HTGC)

Cromatografia com fluidez aumentada - Enhanced Fluidity Chromatograpy (EFC)

Politetrafluoroetileno (PTFE)

Cromatografia Gasosa de Alta resolução - High Resolution Gas Chromatography (HRGC)

Empresa Brasileira de Pesquisa Agropecuária (EMBRAPA)

Extração com Fluido Supercrítico - Supercritical Fluid Extraction (SFE)

Extração Acelerada com Solvente - Accelerated Solvente Extaction (ASE)

Organização Internacional de Padronização - Internacional Organization for Standardization (ISO)

Programa Nacional de Produção e Uso de Biodiesel (PNPB)

Programa de Integração Social (PIS)

Programa de Formação do Patrimônio do Servidor Público (PASEP) 


\section{Sumário}

Resumo

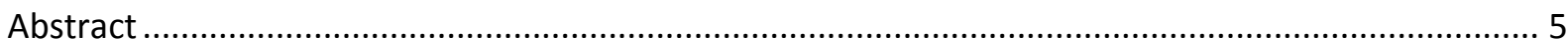

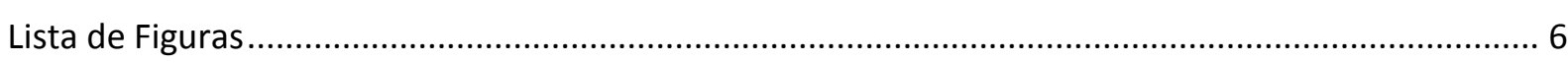

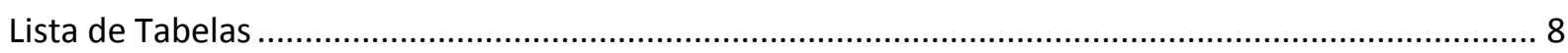

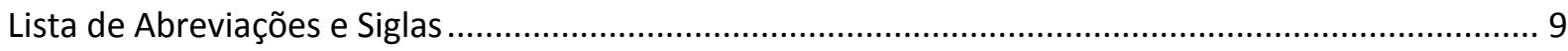

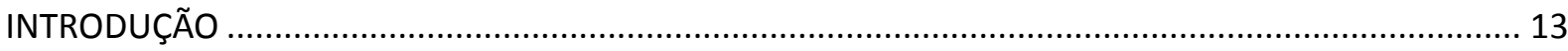

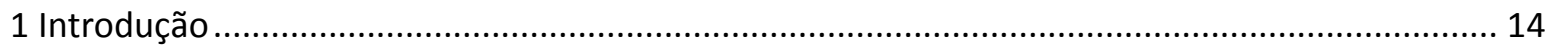

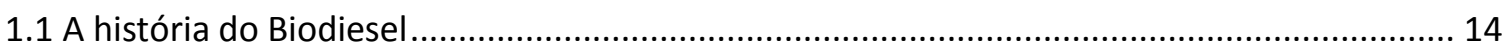

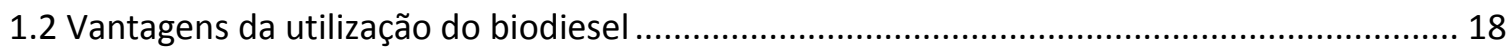

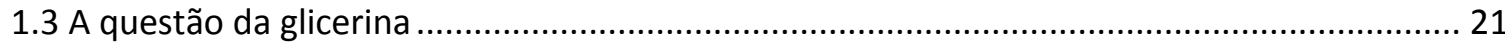

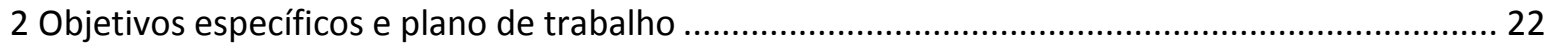

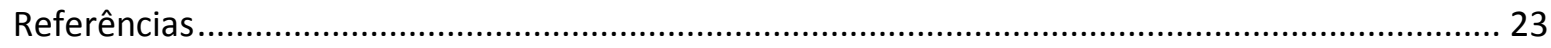

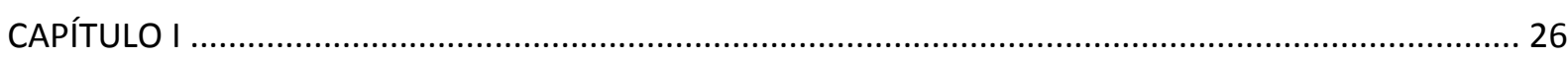

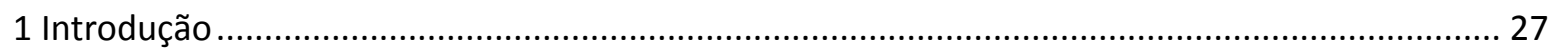

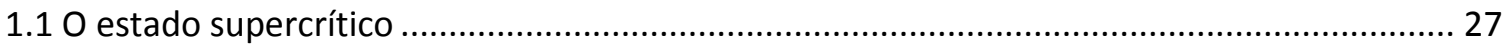

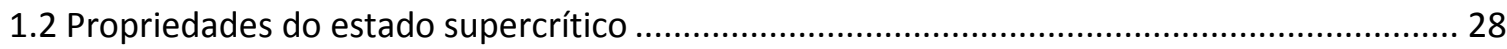

1.3 Princípios da produção de biodiesel por fluido supercrítico................................................... 32

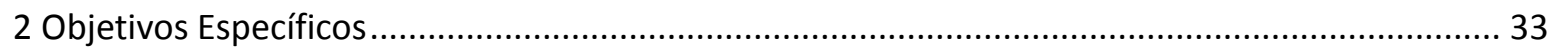

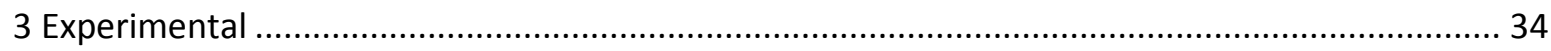

3.1 Montagem do aparato experimental para realização da síntese do biodiesel........................ 34

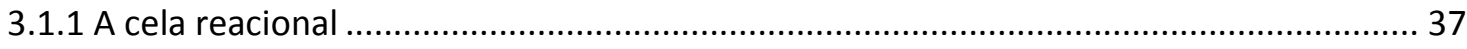

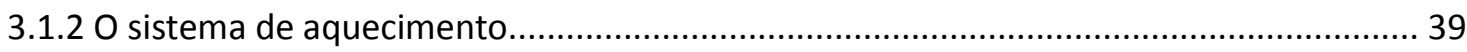

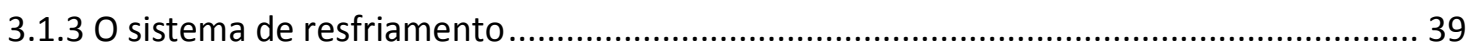

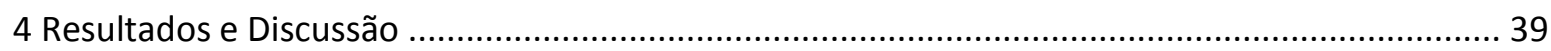

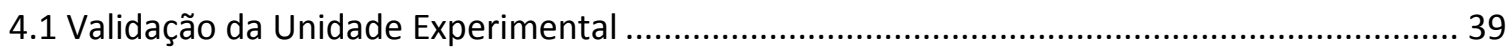

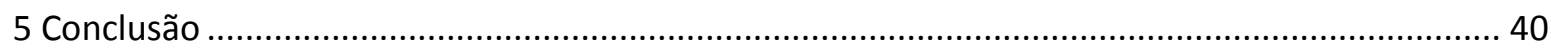

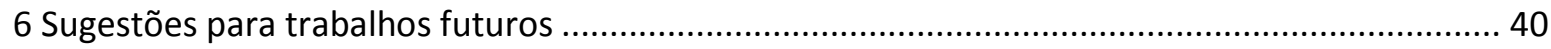

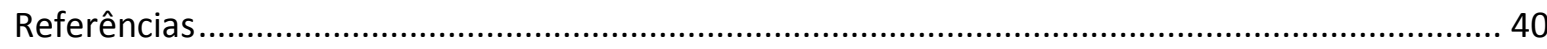

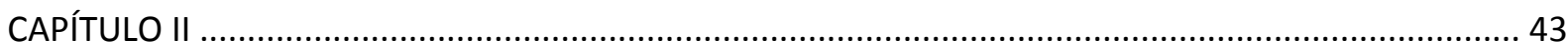

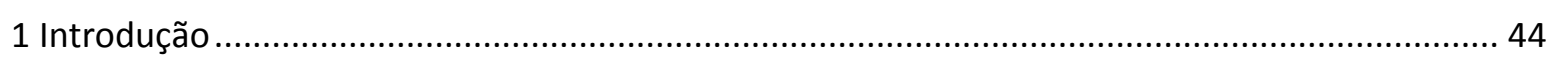

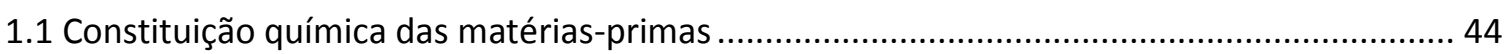

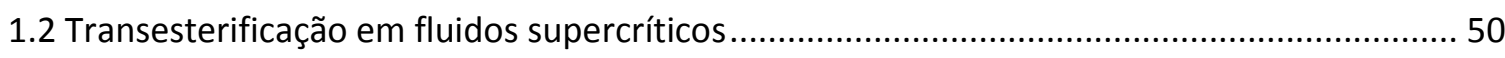

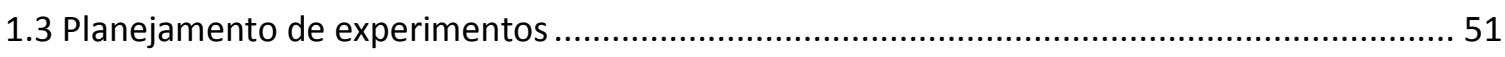

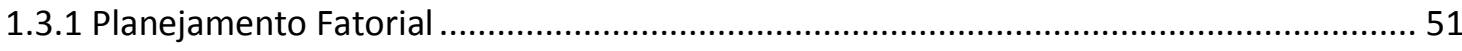

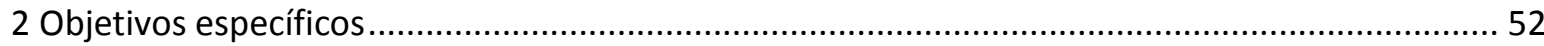




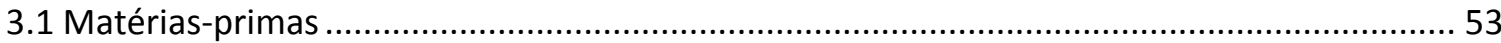

3.2 Procedimento experimental para produção de biodiesel em reator supercrítico .................. 54

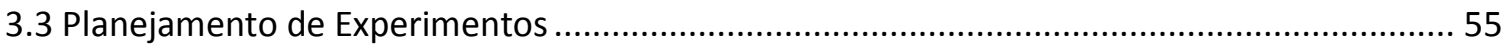

3.4 Síntese do biodiesel de óleo de soja em metanol e etanol pressurizados ............................. 58

3.5 Preparo da amostra para quantificação dos ésteres - processo de separação dos produtos da

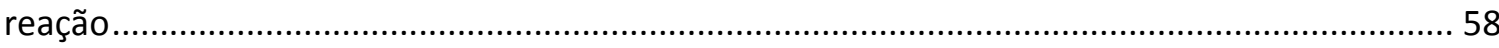

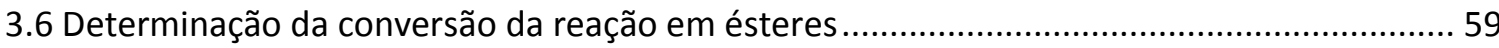

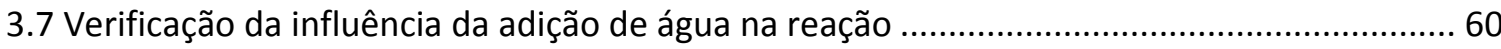

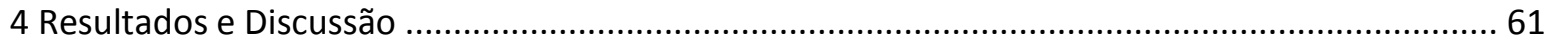

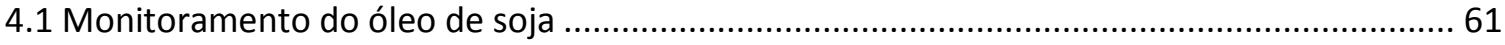

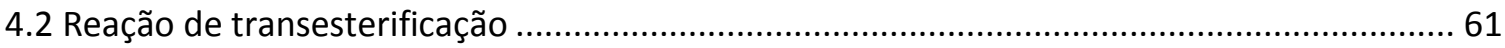

4.3 Monitoramento da reação de transesterificação - determinação dos percentuais de

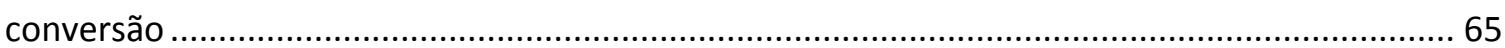

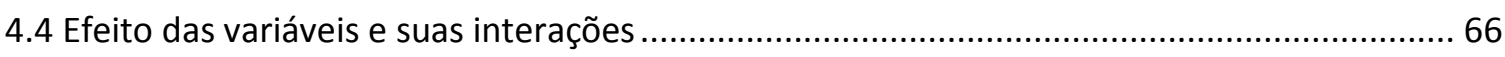

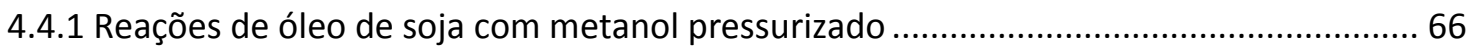

4.4.2 Reações de óleo de soja com etanol pressurizado ........................................................ 70

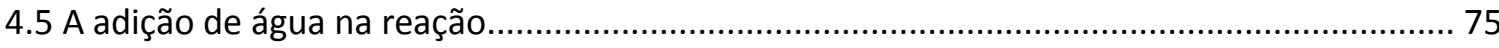

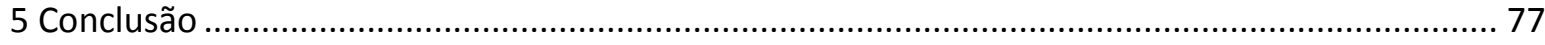

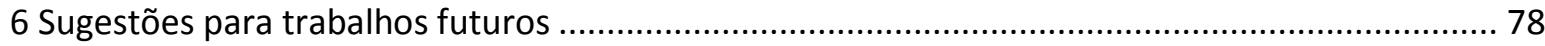

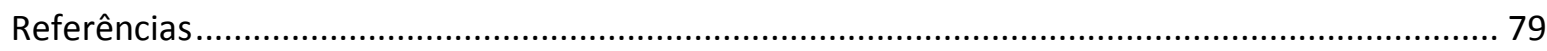

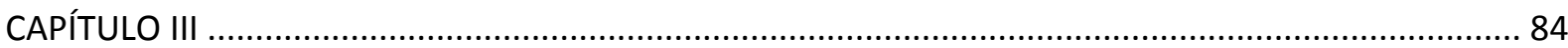

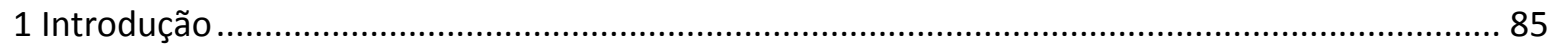

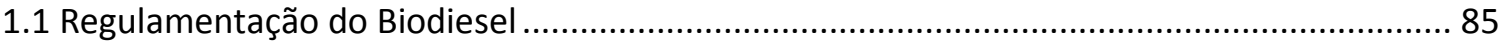

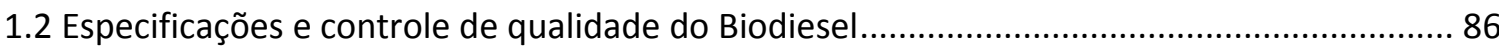

1.3 Métodos Analíticos para avaliação da qualidade do biodiesel - Avaliação do processo

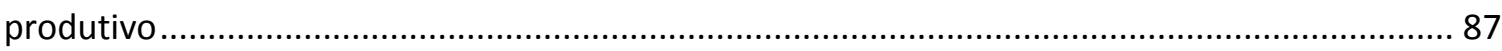

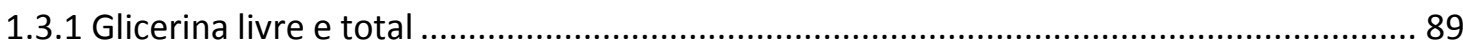

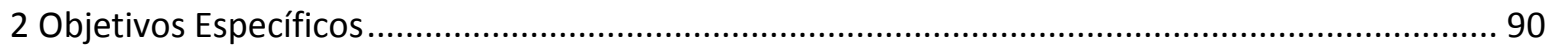

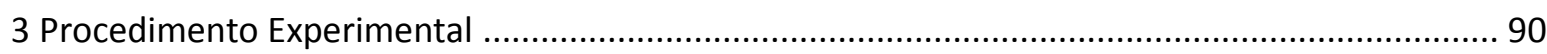

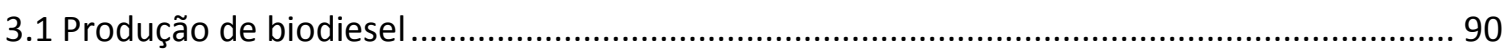

3.2 Análises das amostras de biodiesel produzidas ..................................................................... 91

3.3 Preparação das amostras para análise do desenvolvimento da metodologia de análise ...... 92

3.4 Desenvolvimento da metodologia para análise por HRGC .................................................... 92

3.5 Parâmetros analisados para a avaliação do desempenho da metodologia - Parâmetros de Validação 
3.5.1 Curva analítica, linearidade e determinação da quantidade de mono, di e triglicerídeos

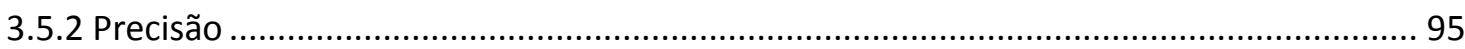

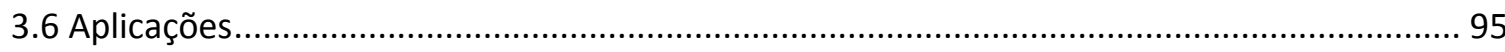

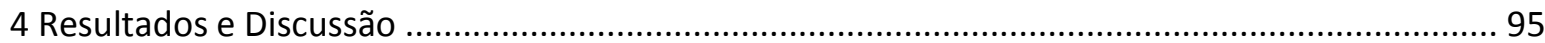

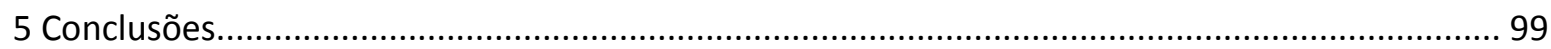

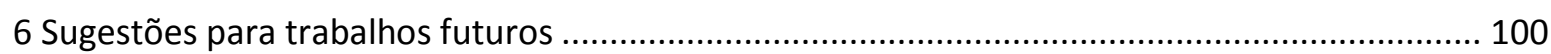

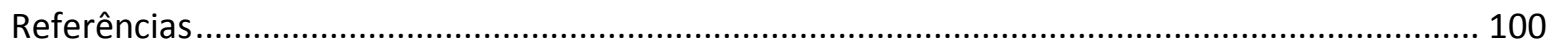

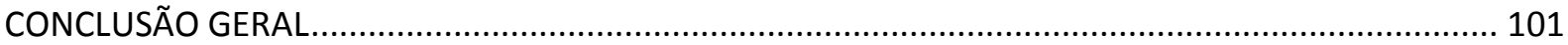




\section{INTRODUÇÃO}

" $\theta$ fato de que os óleos vegetais possam ser utilizados com facilidade parece ser insignificante para os dias de hoje, mas estes óleos podem talvez se tornar importantes no futuro, da mesma forma como são importantes hoje os olleos minerais e os produtos do alcatrão. Atlguns anos atrás, os últimos não estavam muito mais desenvolvidos do que os óleos vegetais nos dias de hoje e, mesmo assim. atingiram a importância que thes é hoje conferida. Ninguém pode prever a importância que estes óleos terão para o desenvolvimento das colônias. De qualquer forma, eles permitiram demonstrar que a energia dos motores poderá ser produzida com o calor do fol, que sempre estará disponivel para fins agricolas, mesmo quando todos os nossos estoques de combustiveis sólidos e liquidos estiverem exauridos."

CRudolf Diesel - 1972 


\section{Introdução}

Devido à premência das questões ambientais, as fontes energéticas alternativas vêm ocupando um espaço cada vez maior por medidas e discussões governamentais. Podem-se citar alguns exemplos, tais como a energia solar, a eólica, energia hídrica e a biomassa. Assim, é crescente o interesse em um desenvolvimento tecnológico baseado na sustentabilidade, buscando fontes alternativas de energia. Dentro do cenário de energia limpa, o biodiesel é uma alternativa atrativa que pode ser obtida através de fontes renováveis.

\subsection{A história do Biodiesel}

O motor diesel tem sido escolhido para aplicações na agricultura, na construção civil, na indústria e no transporte rodoviário por mais de 50 anos. Apesar de não ser muito utilizado para carros de passeio nos Estados Unidos (<1\%), o óleo diesel é amplamente aceito na Europa para esta aplicação, respondendo por mais de $33 \%$ de todo o mercado. ${ }^{1}$ Portanto, neste seguimento, a procura por um substituto para o diesel, por meio de recursos energéticos renováveis, torna-se um componente importante na busca de uma economia energética sustentável. ${ }^{2}$

Quando estudamos a história dos combustíveis alternativos podemos observar que o uso de óleos e gorduras de origem vegetal ou animal como combustível remonta ao fim do século XIX, quando Rudolph Diesel, inventor do motor à combustão interna que leva seu nome, utilizou em seus ensaios petróleo crú e óleo de amendoim. ${ }^{3}$ Diesel em seus artigos históricos ${ }^{4,5}$ afirmava que o uso de óleos vegetais provia subsídios para as colônias tropicais europeias, buscando torná-las autossuficientes em aplicações fundamentais como a geração de energia. Este anseio pela conquista de uma maior independência energética também se estendeu a maioria dos países europeus que possuíam colônias africanas, tais como Bélgica, França, Itália e o Reino Unido. ${ }^{6}$

Óleos vegetais também foram usados como combustíveis de emergência, dentre outras aplicações na Segunda Guerra Mundial.

Porém, a alta viscosidade dos óleos vegetais apresentava problemas ao motor. Apesar de já terem sido consideradas modificações no motor, com o emprego de sistemas de injeção de alta pressão ${ }^{7}$, reduções na viscosidade de óleos vegetais eram usualmente obtidas do seu pré-aquecimento. ${ }^{8}$ Geralmente o motor era acionado com diesel de petróleo e após alguns minutos de operação, a alimentação do motor era alterada para óleo vegetal. 
A viscosidade cinemática de óleos vegetais é cerca de uma ordem de magnitude superior à combustíveis convencionais derivados do petróleo. Altas viscosidades causam a má atomização do combustível na câmara de combustão do motor, acarretando sérios problemas operacionais como a ocorrência de depósitos em suas partes internas. ${ }^{3}$ Desde o renascimento do interesse internacional por combustíveis renováveis, a partir do final da década de 70 , quatro soluções passaram a ser investigadas para resolver o problema da viscosidade de óleos vegetais: a transesterificação, a pirólise, a diluição no óleo diesel convencional derivado do petróleo, e a microemulsificação. ${ }^{3,9,10}$ Destes, a transesterificação é o método mais comum e leva à obtenção de alquil monoésteres de óleos vegetais e gordura animal, hoje denominado biodiesel quando empregado para fins combustíveis. Apesar disso, a pirólise e o craqueamento representam estratégias que também foram muito divulgadas historicamente. Frações artificiais de "gasolina", "querosene" e diesel foram obtidas na China a partir de óleo de tungue ${ }^{11}$ e de outros óleos vegetais. ${ }^{12}$ Outras estratégias alternativas, como a diluição com diesel de petróleo e, especialmente, a microemulsificação, receberam pouca ou nenhuma atenção durante este princípio histórico dos biocombustíveis de origem vegetal. No entanto, foram descritos experimentos relacionados à mistura de petrodiesel com óleo de algodão. ${ }^{13}$

De acordo com Demirbas, ${ }^{14}$ um dos primeiros usos de óleo vegetal transesterificado como combustível em motores de combustão-ignição foi em veículos automotivos de carga pesada na África do Sul antes da Segunda Guerra Mundial. A primeira patente de biodiesel foi atribuída ao pesquisador G. Chavanne, da Universidade de Bruxelas, na Bélgica, em 1937, que descobriu o processo de transesterificação. A transesterificação de biolipídios foi patenteada nos Estados Unidos por Colgate em 1940, um ano que deu início a uma década em que a glicerina era usada na fabricação de explosivos. ${ }^{15}$

Posteriormente, questões ambientais retornaram a exercer importante influência sobre decisões acerca do uso de combustíveis derivados de óleos vegetais. Por exemplo, os chamados "Clean Air Act Amendments" de 1990 e o "Energy Policy Act" de 1992 tornaram obrigatório o uso de combustíveis alternativos ou "limpos" em frotas cativas de ônibus e de caminhões. Novos termos aditivos, que foram incorporados ao "Energy Policy Act", se tornaram lei em 1998 e os incentivos nela definidos para uso do biodiesel, puro ou em mistura com o diesel de petróleo, 
justificam o aumento significativo da produção e uso deste biocombustível nos Estados Unidos. ${ }^{6}$

No Brasil, como nos outros países, na década de 40 ocorreu uma das primeiras tentativas de aproveitamento energético dos óleos e gorduras em motores à combustão interna. No entanto, não se tem notícias de que a rota de transesterificação tenha sido estudada nesta época. ${ }^{16}$

No final do século XX, o Governo Federal volta a discutir o uso de biodiesel, sendo efetuados vários estudos por comissões interministeriais e em parceria com universidades e centros de pesquisa. Em 2002, a etanólise (devido à grande produção dessas matérias-primas no Brasil $^{17}$ de óleos vegetais foi considerada como a rota principal para um programa de substituição do diesel de petróleo batizado na Portaria MCT ํo 702, de 30 de outubro de 2002 como PROBIODIESEL. ${ }^{16}$

A partir de 2003 um novo impulso é dado a essa área e um Decreto Presidencial, de 2 de julho de 2003, criou um Grupo de Trabalho Interministerial, encarregado de apresentar estudos da viabilidade do uso como combustível de óleos, gorduras e derivados, e indicar as ações necessárias para a sua implementação. No relatório final, de 4 de dezembro de 2003, esta comissão considera que o biodiesel deve ser introduzido imediatamente na matriz energética brasileira e recomenda que: o uso não deve ser obrigatório; não deve haver uma rota tecnológica ou matéria-prima preferencial para a produção de biodiesel e, deve ser incluído o desenvolvimento socioeconômico de regiões e populações carentes. ${ }^{16}$

Para implementar estas sugestões, foi então criada, pelo Decreto Presidencial de 23 de dezembro de 2003, uma Comissão Executiva Interministerial (CEIB) composta por 14 ministérios e coordenada pela Casa Civil. Esta comissão possui como unidade executiva um Grupo Gestor formado por representantes de 10 ministérios, além de membros oriundos da Embrapa, ANP, BNDS e Petrobrás, e é coordenado pelo Ministério das Minas e Energia. Após um ano de amadurecimento, foi lançado o Programa Nacional de Produção e Uso de Biodiesel (PNPB) em sessão solene no Palácio do Planalto no dia 4 de dezembro de 2004, sendo o seu principal objetivo garantir a produção viável economicamente do biocombustível, tendo como tônica a inclusão social e o desenvolvimento regional. ${ }^{16}$

A principal ação legal do PNPB foi a introdução de biocombustíveis derivados de óleos e gorduras na matriz energética brasileira pela Lei ํㅜㄴ 11.097, de 
13 de janeiro de 2005. No artigo $4^{\circ}$, essa lei define ainda que Biodiesel é o biocombustível derivado de biomassa renovável para uso em motores à combustão interna com ignição por compressão ou, conforme regulamento, para geração de outro tipo de energia, que possa substituir parcial ou totalmente combustíveis de origem fóssil. Por esta definição não existe nenhuma restrição quanto à rota tecnológica, sendo possível utilizar como biodiesel os produtos obtidos pelos processos de transesterificação, esterificação e craqueamento. No entanto, a Agência Nacional do Petróleo (ANP), na Resolução ANP no 42 de 24 de novembro de 2004, regulamentou apenas o uso de ésteres metílicos ou etílicos de ácidos graxos, sejam esses obtidos por transesterificação ou esterificação. A Resolução ANP no 41 de 24 de novembro de 2004 regulamentou, ainda, que, para funcionar em nível comercial, as indústrias de biodiesel deveriam receber autorização dessa agência. $^{16}$

As regras tributárias do biodiesel referentes às contribuições federais (PIS/PASEP e COFINS) foram estabelecidas pela Lei $\mathrm{n}^{0} 11.116$, de 18 de maio de 2005, e os Decretos no 5.297, de 6 de dezembro de 2004, e no 5.457, de 6 de junho de 2005. Ficou determinado que esses tributos fossem cobrados uma única vez e que o contribuinte fosse o produtor industrial de biodiesel, sendo o valor incidente igual ao coletado na produção de diesel de petróleo. Para garantir o desenvolvimento regional e socioeconômico, foram estabelecidos, conforme a oleaginosa adquirida pelo industrial, três níveis distintos de redução destes tributos: $100 \%$ no caso de mamona ou a palma produzida nas regiões norte, nordeste e no semiárido pela agricultura familiar; $67,9 \%$ para qualquer matéria-prima que fosse produzida pela agricultura familiar, independentemente da região e, 30,5\% para mamona ou a palma produzida nas regiões norte, nordeste e no semiárido pelo agronegócio. Os industriais que adquiriram matéria-prima em arranjos produtivos que incluam a agricultura familiar, com uma garantia de compra a preços preestabelecidos, receberam o Selo Combustível Social. Este selo, regulamentado pelo Ministério de Desenvolvimento Agrário, nas Instruções Normativas no 01 e 02 de 05 de julho e 30 de setembro de 2005, garantia ao industrial, além das isenções fiscais, melhores condições de financiamento junto ao BNDES e outros bancos.

Para incentivar o mercado de biodiesel antes do início da obrigatoriedade, foram realizados leilões de biodiesel, a cargo da ANP, onde a Petrobrás garantia, 
para industriais que possuíssem o Selo Social, a compra de biodiesel até o volume necessário para a adição de $2 \%$ de biodiesel ao diesel. ${ }^{16}$

Mundialmente passou-se a utilizar uma nomenclatura para identificar a concentração de biodiesel em mistura com diesel mineral: $B X X$, onde $X X$ é a percentagem em volume de biodiesel na mistura. Por exemplo, B2, B5, B20 e B100 são combustíveis com concentrações de 2\%, 5\%, 20\% e 100\% de biodiesel, respectivamente.

\subsection{Vantagens da utilização do biodiesel}

A utilização de biodiesel tem apresentado um potencial promissor no mundo inteiro. Em primeiro lugar, pela enorme contribuição ao meio ambiente, com a redução qualitativa e quantitativa dos níveis de poluição ambiental; em segundo lugar, como fonte estratégica de energia renovável em substituição ao diesel, o que reduz a dependência do óleo diesel importado; e em terceiro lugar, a utilização de óleos vegetais como fonte de biomassa proporciona uma geração descentralizada de energia possibilitando o fortalecimento do agronegócio, apoiando a agricultura familiar e gerando empregos de forma dieta e indireta em áreas rurais.

No que tange a contribuição ambiental pode-se dizer que a principal característica do biodiesel é seu alto numero de cetano.

O número de cetano representa uma das mais importantes propriedades do diesel automotivo e seu aumento geralmente resulta em redução da emissão pela exaustão, diminuindo o consumo de combustível e reduzindo o barulho do motor. ${ }^{18}$ Como equações para predizer o número de cetano não são aplicáveis ao biodiesel, um parâmetro alternativo adotado para o biodiesel é o índice de cetano. ${ }^{19}$

No mesmo contexto que diz respeito às vantagens ambientais apresentadas pelo biodiesel, estudos indicaram que a utilização de $20 \%$ (v/v) de biodiesel no diesel convencional proporciona uma redução na emissão de material particulado de 26,8\% (v/v), monóxido de carbono de 72,8\% (v/v) e hidrocarbonetos de $73,2 \%(v / v) .{ }^{20}$ Adicionalmente, a ausência total de enxofre confere ao biodiesel uma grande vantagem, pois não há qualquer emissão dos gases sulfurados (como exemplo as mercaptanas e o dióxido de enxofre) normalmente detectados no escape dos motores movidos a diesel.

A diminuição das emissões ocorre porque, comparado com a combustão do diesel convencional, a combustão do biodiesel é mais completa devido a 
presença de oxigênio nas moléculas de seus constituintes (cerca de 10\%). Porém, a melhor combustão resulta em temperaturas mais elevadas, que favorece as reações de formação de óxidos de nitrogênio $\left(\mathrm{NO}_{\mathrm{x}}\right)$, embora no uso de misturas (biodiesel/diesel) esse aumento de óxidos de nitrogênio seja minimizado quando comparado ao biodiesel puro.

SZYBIST e colaboradores ${ }^{21}$, atribuíram o aumento nas emissões de NOx ao processo de queima nos motores. Como resultado de investigações sobre impactos do queima do biodiesel no aumento das emissões de NOx, ZHANG e BOEHMAN $^{22}$ afirmaram que tal aumento não pode ser consequência apenas do efeito da injeção e sugeriram que devem existir outros fatores envolvidos. A natureza química dos ésteres alquílicos que constituem o biodiesel influencia fortemente nas emissões de NOx. De acordo com os estudos de SZYBIST e colaboradores ${ }^{22}$, MCCORMICK e colaboradores ${ }^{23}$ e KNOTHE, ${ }^{24}$ decrescendo o comprimento da cadeia e/ou aumentando o número de ligações duplas resulta no aumento das emissões de NOx do biodiesel etílico.

MOSER $^{25}$ afirmou que o NOx é formado em temperaturas elevadas na câmara de combustão de motores diesel quando o oxigênio reage com nitrogênio ambos presentes no ar de combustão. Portanto, é necessário diminuir a temperatura de chama na câmara para reduzir a formação de NOx. O mesmo autor mencionou a recirculação do gás de exaustão, redução catalítica seletiva e catalisadores para oxidação de diesel como sendo métodos para diminuir as emissões de NOx.

Excetuando-se alguns catalisadores de oxidação, os motores diesel geralmente não têm usado tratamento de gases para controle de emissões. Os catalisadores comumente utilizados nos veículos que cuja ignição é feita por faísca não são adequados para os motores diesel porque requerem proporção da mistura ar-combustível praticamente estequiométrica de modo a obter redução simultânea de monóxido de carbono, hidrocarbonetos residuais e NOx, pois os motores diesel operam com excesso de oxigênio.

Os catalisadores de oxidação que operam em alguns motores diesel são capazes de reduzir os níveis de particulados pela oxidação de hodrocarbonetos adsorvidos nas partículas de carbono resultantes de combustão incompleta, mas não conseguem oxidar as partículas nem diminuir o teor de $\mathrm{NO}_{\mathrm{x}}$. Inovações recentes incluem filtros e purgadores que forçam os gases efluentes a passarem através do material cerâmico poroso que retém os particulados. Os purgadores, que são muito 
sensíveis à presença de compostos sulfurados, convertem $\mathrm{NO}_{x}$ cataliticamente em compostos estáveis que são coletados dentro das partículas do catalisador até serem removidos durante os períodos de regeneração. Para melhorar o suprimento de ar no motor, turbos injetores de geometria variável têm sido desenvolvidos no intuito de ampliar os limites de operação no qual uma quantidade adequada de ar é provida para manter um nível baixo de particulados nos gases efluentes. Além disso, resfriadores de ar tem sido empregados para diminuir a temperatura do ar de combustão visando ao decréscimo de particulados e $\mathrm{NO}_{\mathrm{x}}{ }^{6}$

Em relação à biomassa para a produção de biodiesel, sabe-se que, nos tempos modernos, o biodiesel é derivado a partir de muitas matérias-primas distintas, incluindo óleos vegetais, gorduras animais, óleos usados em frituras, e até matérias graxas de alta acidez. Geralmente, fatores como a geografia, o clima e a economia local determinam quais óleos vegetais apresentam maior interesse e melhor potencial para emprego como biodiesel. Assim, na Malásia e na Indonésia o óleo de dendê é largamente utilizado, na Índia e no sudeste asiático pinhão roxo é a principal matéria-prima, na Europa a preferência real é sobre o óleo de colza (canola) enquanto que nos Estados Unidos e Brasil, o óleo de soja é considerado como a principal matéria-prima. O Brasil apresenta em sua geografia grandes vantagens econômicas por se situar em uma região tropical com altas taxas de luminosidade e temperaturas médias anuais, associado à disponibilidade hídrica e regularidade de chuvas, tornando-se o país com maior potencial para produção de oleaginosas utilizadas como biomassa para energias renováveis.

Porém, além do desenvolvimento científico e tecnológico, uma questão que permeia a utilização de biomassa para produzir combustível é o dilema entre a segurança alimentar e energética. Se, por um lado, Brasil e Estados Unidos incentivam a produção dos biocombustíveis chamados de primeira geração, tais como álcool e biodiesel, por outro lado países como Cuba e Venezuela e organismos internacionais mostram a preocupação no aumento da crise dos alimentos na América Latina e outras regiões pobres do planeta, argumentando que ela foi agravada pelo deslocamento das áreas tradicionalmente utilizadas para o cultivo de alimentos para a produção de insumos destinados à indústria dos biocombustíveis.

No atual estado da arte é provável que em muitos países ocorra o deslocamento das áreas destinadas à produção de alimentos para que se possam 
produzir biocombustíveis, mas no Brasil há várias opções viáveis para que não haja tal problema. Por exemplo, pastagens já abandonadas pela agropecuária no centrooeste ou áreas degradadas da Amazônia poderiam servir, respectivamente, de terras para o plantio de cana-de-açúcar e palmáceas oleaginosas destinadas à produção dos biocombustíveis, sem prejudicar a produção de alimentos, além disso, o Brasil explora menos de um terço de sua área agricultável, o que constitui a maior área para expansão agrícola do mundo.

\subsection{A questão da glicerina}

Na reação de transesterificação para produção de bodiesel são formados ésteres metílicos de ácidos graxos e glicerol. Teoricamente, para cada 3 mols de ésteres metílicos ou etílicos de ácidos graxos é gerado $1 \mathrm{~mol}$ de glicerol; aproximadamente $10 \%$ da massa total do produto. ${ }^{26}$ Desse modo, um excedente de glicerol gerado é acrescentado no mercado mundial. Portanto, é consenso na comunidade científica e nas indústrias do setor que a colocação do glicerol é um sério problema para a produção de biodiesel em grandes quantidades, sendo fundamental buscar alternativas para o consumo desse volume extra de glicerol, na forma bruta e/ou como derivados de alto valor agregado, viabilizando economicamente o aumento da produção de biodiesel.

O glicerol também tem inúmeras aplicações na indústria ${ }^{27}$, como fármacos, cuidados pessoais, alimentação, resinas alquílicas, tabaco, detergentes, celofane e explosivos, no entanto, a quantidade utilizada é muito menor do que a indústria do biodiesel produz atualmente. Nesse contexto estudos sobre o uso do glicerol na obtenção de blocos de construções quirais (chiral building blocks) vem sendo estudado para o emprego desses derivados na síntese de fármacos e produtos naturais. ${ }^{28}$

O glicerol também é uma matéria-prima barata e muito versátil, constituindo-se em uma alternativa real e viável para atuar como percursor de produtos industriais de alto valor agregado como acetais e cetais utilizados como surfactantes, ${ }^{29}$ flavorizantes ${ }^{30}$ e solventes para uso em medicina. ${ }^{31}$

A acroleína (produto da desidratação do 3-hidróxi-propanal, este produto da desidratação da glicerina), é um importante intermediário para a produção de ácido acrílico, que por sua vez é utilizado na produção de polímeros absorventes para uso em fraldas descartáveis, tintas, adesivos, objetos decorativos, entre outros. A 
acroleína é também usada na produção da metionina, aminoácido empregado na indústria alimentícia. ${ }^{32}$

Uma das reações de transformação química do glicerol mais estudadas na literatura é a hidrogenólise a 1,2 e 1,3 propanodiol (1,2 PD e 1,3 PD). O primeiro produto, também conhecido como propileno-glicol, tem aplicação como agente anticongelante e na produção de polímeros. Já o 1,3 PD é utilizado na produção de fibras sintéticas de poliésteres. Outra aplicação interessante para a hidrogenólise da glicerina é numa rota para produção de propeno. Este produto é um importante insumo na produção de plásticos e consumido em larga escala no Brasil. Ele é, normalmente, produzido a partir da nafta petroquímica, pelo processo de craqueamento a vapor, e há previsões para uma demanda crescente, que deverá ultrapassar a oferta deste produto no mercado nacional no início da próxima década, ocasionando problemas na balança de pagamentos. ${ }^{32}$

Pode-se, portanto, concluir, que os problemas relacionados ao excedente de glicerina no mercado estão sendo solucionados, o que viabiliza a produção de biodiesel para o país. Solucionados os problemas econômicos relacionados à produção de biodiesel, pesquisas estão constantemente sendo realizadas para melhorar o processo de produção de biodiesel. Este trabalho de doutorado se insere em uma linha de pesquisa que tem por propósito o desenvolvimento de processos alternativos de produção de biodiesel. O método de produção do biodiesel proposto neste projeto utiliza metanol e etanol pressurizados e dispensa o uso de catalisadores. Também está inserido nesta tese o estudo da caracterização das amostras de biodiesel por meio de cromatografia gasosa de alta resolução.

\section{Objetivos específicos e plano de trabalho}

Os objetivos específicos deste estudo são:

- Desenvolvimento de instrumentação para estudo das reações com metanol e etanol pressurizados

- Produção de biodiesel metílico e etílico do óleo de soja por meio de reação de transesterificação não catalítica em condições sub e supercríticas

- Estudo da utilização de Cromatografia Gasosa de Alta Resolução para análise de acilgliceróis.

Os procedimentos experimentais deste trabalho foram realizados em três etapas distintas. Na primeira etapa construiu-se um reator químico; na segunda 
etapa foi realizada a reação de transesterificação do óleo de soja para produção do biodiesel, utilizando o reator construído na primeira etapa. Por fim, na terceira etapa, foi efetuado um estudo experimental das análises de acilgliceróis em biodiesel utilizando Cromatografia Gasosa de Alta Resolução. Portanto, para melhor organização, esta tese foi dividida em três capítulos.

No capítulo 1 primeiramente é apresentada uma breve revisão bibliográfica com relação aos fluidos supercríticos, feita com um caráter introdutório. Em seguida apresenta-se uma descrição detalhada da unidade experimental desenvolvida e adotada para a produção de biodiesel com metanol e etanol em altas pressões e temperaturas.

O capítulo 2 inicia-se com uma introdução sobre as tecnologias de produção de biodiesel, incluindo a utilização de fluídos supercríticos como solventes. Em seguida é descrito o desenvolvimento experimental do procedimento utilizado para a obtenção da reação, incluindo o planejamento fatorial utilizado na otimização do processo. O texto evolui para uma interpretação e discussão dos resultados experimentais e, finalmente, são apresentadas as conclusões inerentes aos resultados.

No capítulo 3, além de uma breve introdução sobre as especificações do biodiesel, descreve-se o desenvolvimento, otimização e validação de metodologia para análise de acilgliceróis em biodiesel utilizando Cromatografia Gasosa de Alta Resolução com discussão dos resultados abrangendo este tema específico.

\section{Referências}

1 BROGE, J. L. Revving up for diesel. Automotive Engineering International Magazine, v. 110, n. 2, p. 40-49, 2002.

2 AYHAN, T.; AL MADANI, H. Feasibility study of renewable energy powered seawater desalination technology using natural vacuum technique. Renewable Energy, v. 35, n. 2, p. 506-512, 2010.

3 HANNA, M. A.; MA, F. Biodiesel production: a review. Bioresource Technology, v.70, n. 1, p.1-15, 1999.

4 DIESEL, R. The diesel oil-engine. Engineering, v. 93, p. 395-406, 1912. 
5 DIESEL, R. The diesel Oil-engineering and its industrial importance particularly for Great Britain. Proceedings of Institution of Mechanical Engineers, p. 179-280, 1912.

6 KNOTHE, G.; GERPEN, J.V.; HRAHL, J.; RAMOS, L. P. Manual de biodiesel. São Paulo: Edgard Blücher, 2006. 340 p.

7 TATTI, E.; SIRTORI, A. Use of peanut oil in injection, high-compression, highspeed automobile motors. Energia Termica, v. 5, p. 59-64, 1937.

8 MATHOT, R. E. Vegetable oils for internal combustion engineer. Engineer, v. 132, p. 138-139, 1921.

9 DEMIRBAS A. Chemical and fuel properties of seventeen vegetable oils. Energy Sources, v. 25, n. 7, p. 721-728, 2003.

10 SCHWAB, A. W.; BAGBY, M. O.; FREEDMAN, B. Preparation and properties of diesel fuels from vegetable oils. Fuel, v. 66, n. 10, p. 1372-1378, 1987.

11 CHANG, C. -C.; WAN, S. -W. China's motors fuels from tung oil. Industrial \& Engineering Chemistry Research, v. 39, n. 12, p. 1543-1548, 1947.

12 CHENG, F. -W. China produces fuels from vegetable oils. Chemical Metallurgical Engineering, v. 52, p. 99, 1945.

13 TU, C. -M.; KU, T.-T. Cottonseed oil as a diesel oil. Journal of Chemical Industry and Engineering (China), v. 3, p. 211-221, 1936.

14 DEMIRBAS, A. Biodiesel : a realistic fuel alternative for diesel engines. London: Springer-Verlag, 2008. $218 \mathrm{p}$.

15 FALCÃO, Pedro Wagner de Carvalho. Produção de biodiesel em meio supercrítico. 2011. 305 f. Tese (Doutorado em Engenharia Química) - Instituto Alberto Luiz Coimbra de Pós-Graduação e Pesquisa de Engenharia, Universidade Federal do Rio de Janeiro, Rio de Janeiro, 2011.

16 SUAREZ, P. A. Z.; MENEGHETTI, S. M. P. 70aniversário do biodiesel em 2007: evolução histórica e situação atual no Brasil. Química Nova, v. 30, n. 8, p. 20682071, 2007.

17 RAMOS, L. P.; WIHELM, H. M. Current status of biodiesel development in Brasil. Applied Biochemistry and Biotechnology, v. 121-124, n. 1-3, p. 807-820, 2005.

18 SERDARI, A.; EURIPIDES, L.; STOURNAS, S. Impact of esters of mono- and dicarboxylic acids on diesel fuel quality. Industrial \& Engineering Chemistry Research, v. 38, n. 9, p. 3543-3548, 1999.

19 DORADO, M. P.; BALLESTEROS, E.; ARNAL, J. M.; GÓMEZ, J.; JIMÉNEZ, F. J. $\mathrm{L}$. Testing waste olive oil methyl ester as a fuel in a diesel engine. Energy Fuels, $v$. 17 , n. 16, p. 1560-1565, 2003. 
20 LEE, K. -T.; FOGLIA, T. A.; CHANG, K. -S. Production of alkyl ester as biodiesel from fractionated lard and restaurant grease. Journal of the American Oil Chemists' Society, v. 79, n. 2, p. 191-195, 2002.

21 SZYBIST, J. P.; KIRB, S. R.; BOEHMAN, A. L. NO ${ }_{x}$ emissions of alternative diesel fuels: a comparative analysis of biodiesel and FT diesel. Energy \& Fuels, v. 19, n. 4, p. 1484-1492, 2005.

22 ZHANG, Y.; BOEHMAN, A. L. Impact of biodiesel on $\mathrm{NO}_{\mathrm{x}}$ emissions in a common rail direct injection diesel engine. Energy \& Fuels, v. 21, n. 4, p. 2003-2012, 2007.

23 MCCORMICK, R. L.; GRABOSKI, M. S.; ALLEMAN, T.L.; HERRING, A.M. Impact of biodiesel source material and chemical structure on emissions of criteria pollutants from a heavy-duty engine. Environmental Science \& Technology, v. 35, n. 9, p. 1742-1747, 2001.

24 KNOTHE, G. Dependence of biodiesel fuel properties on the structure of fatty acid alkyl esters. Fuel Processing Technology, v. 86, n. 10, p. 1059-1070, 2005.

25 MOSER, B. R. Biodiesel production, properties, and feedstocks. In Vitro Cellular and Developmental Biology - Plant, v. 45, n. 3, p. 229-266, 2009.

26 ZHOU, C. H.; BELTRAMINI, J. N.; FAN, Y. X.; LU, G. Q. Chemoselective catalytic conversion of glycerol as a biorenewable source to valuable comodity chemicals.

Chemical Society Reviews, v. 37, n. 3, p. 527-549, 2008.

27 PAGLIARO, M.; CIRIMNNA, R.; KIMURA, H.; ROSSI, M.; PINA, C. D. From glycerol to value-added products. Angewandte Chemie International Edition, v. 46, n. 34, p. 4434-4440, 2007.

28 BEATRIZ, A.; ARAÚJO, Y. J. K.; DE LIMA, D. P. Glicerol: um breve histórico e aplicação em síntese estereosseletivas. Química Nova, v. 34, n. 2, p. 306-319, 2011.

29 PIASECKI, A.; SOKOLOWSKI, A.; BURCZYK, B.; KOTLEWSKA, U. Synthesis and surface properties of chemodegradable anionic surfactants sodium (2-n-alkyl1,3-dioxan-5yl) sulfates. Journal of the American Oil Chemists' Society, v. 74, n. 1, p. 33-37, 1997.

30 CLIMENT, M.; VELTRY, A.; CORMA, A. Design of a solid catalyst for the synthesis of a molecule with blossom orange scent. Green Chemistry, v. 4, n. 6, p. 565-569, 2002.

31 SARI, P.; RAZZAK, M.; TUCKER, I. G. Isotopic systems of medium-chain monoand diglycerides for solubilization of lipophilic and hydrophilic drugs. Pharmaceutical Development and Technology, v. 9, n. 1, p. 97-106, 2004.

32 MOTA, C. J. A.; DA SILVA, C. X. A.; GONÇALVES, V. L. C. Gliceroquímica: novos produtos e processos a partir da glicerina de produção de biodiesel. Química Nova, v. 32, n. 3, p. 639-648, 2009. 


\section{CAPÍTULO I}

\section{Desenvolvimento de instrumentação para realização da síntese de biodiesel com etanol pressurizado}




\section{Introdução}

A falta de competitividade econômica do biodiesel frente ao diesel é atualmente um dos grandes impeditivos para a sua efetiva entrada no mercado como um substituto do diesel de petróleo. Seu alto custo é o maior obstáculo para sua comercialização. Vários fatores contribuem para o preço final do biodiesel, incluindo a matéria prima, reagentes, natureza da purificação, armazenamento, etc. Para conferir competitividade econômica ao biodiesel é de primordial importância que novos processos para sua produção sejam desenvolvidos. Esses processos devem primar pelo uso de matérias-primas mais baratas e pela simplificação dos processos de produção e purificação do biodiesel, objetivando a redução dos custos operacionais. Além disso, os mesmos devem evoluir a um patamar em que a qualidade não seja privilégio apenas do produto, mas também do glicerol gerado, conferindo-Ihe um maior valor de mercado.

Uma forma adequada para a produção de biodiesel seria conduzir a reação em meio pressurizado, com um solvente no estado supercrítico. Além de evitar as limitações de transferência de massa, do ponto de vista ambiental o processo de transesterificação supercrítica pode competir com os processos tradicionais de transesterificação que usam catalisadores homogêneos ácidos ou básicos em virtude da geração de produtos mais limpos.

\subsection{0 estado supercrítico}

De acordo com TAYLOR ${ }^{1}$, a descoberta do estado supercrítico é atribuída ao Baron Gagniard de la Tour que encontrou o ponto crítico de uma substância por meio de suas experiências num barril canhão em 1822. Ao ouvir as descontinuidades no som de uma bola de pedra rolando dentro de um canhão cheio de fluidos a várias temperaturas ele observou a temperatura crítica onde não há distinção entre as densidades das fases líquida e gasosa. Já o poder de solvência dos fluidos supercríticos só foi demonstrado pela primeira vez em 1879 por Hannay e Hogarth em um encontro em Londres da Royal Society. Eles observaram que mudanças de pressão causavam solubilização ou precipitação de sais inorgânicos em tetraclorometano ou em metanol supercrítico. ${ }^{2}$ Alguns estudos seguiram a este, principalmente sobre solubilidade de parafinas, apresentados por Villard em $1986 \mathrm{e}$ Prins $1915 .^{3}$ Porém, dado as dificuldades experimentais para a compressão dos gases, as pesquisas foram praticamente abandonadas. Por volta de 1954, infelizmente essa técnica foi marcada por problemas de instrumentação, com a 
teoria fundamental inadequada sobre o estado supercrítico, e foi ofuscada pelo desenvolvimento simultâneo da HPLC. Em função disso, poucos trabalhos foram publicados nas décadas de 60 e 70 . Portanto, apenas 100 anos mais tarde a tecnologia supercrítica começou a ser usada em laboratórios e em escala industrial.

O ponto crítico de um fluido é caracterizado pelo término da coexistência de suas fases no estado líquido e vapor, sendo definido por uma temperatura crítica (Tc) e uma pressão crítica (Pc). O diagrama de fases mostrado na Figura 1.1 permite uma melhor visualização do ponto crítico e da região supercrítica de uma substância.

Figura 1.1 - Diagrama genérico de estados de uma substância pura.

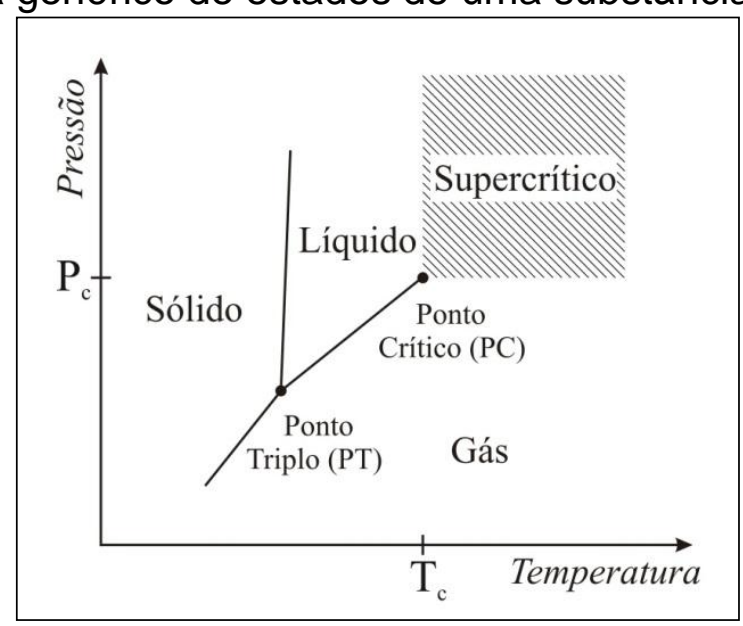

Adaptado de RIZVI ${ }^{4}$

A temperatura crítica de um gás é aquela temperatura acima da qual ele não pode mais ser liquefeito, não importando a quanto se eleve a pressão. Já a pressão crítica é definida como a pressão acima da qual o gás não pode mais ser liquefeito, não importando a quanto se diminua a temperatura. Quando a pressão e temperatura de uma substância estão acima do seu ponto crítico, atinge-se o estado supercrítico. ${ }^{3}$

\subsection{Propriedades do estado supercrítico}

$\mathrm{Na}$ condição supercrítica o gás é relativamente denso comparado com um gás convencional e as forças de solubilização são mais intensas. Nesse estado ocorre a formação de uma névoa densa. ${ }^{5} \mathrm{Na}$ prática, o estado supercrítico é obtido elevando-se a pressão e a temperatura de um gás ou de um líquido de forma que se altere o estado de agregação e, como consequência, modifique as propriedades da 
substância de interesse, tais como difusividade, constante dielétrica, viscosidade, densidade e poder de solvatação, o que modifica o comportamento químico das mesmas. Portanto, as propriedades físicas de um fluido supercrítico são intermediárias entre um gás e um líquido típicos ${ }^{3,6,7}$ (Tabela 1.1).

Tabela 1.1 - Propriedades físico-químicas associadas a diferentes estados de uma substância.

\begin{tabular}{cccc}
\hline & $\begin{array}{c}\text { Densidade } \\
\left(\mathbf{g} . \mathbf{c m}^{-3}\right)\end{array}$ & $\begin{array}{c}\text { Viscosidade } \\
\left(\mathbf{g} . \mathbf{c m}^{-1} \cdot \mathbf{s}^{-1}\right)\end{array}$ & $\begin{array}{c}\text { Coeficiente } \\
\text { de difusão } \\
\left(\mathbf{c m}^{2} \cdot \mathbf{s}^{-1}\right)\end{array}$ \\
\hline Gás & $(0,6-2,0) 10^{-3}$ & $(1-3) 10^{-4}$ & $0,1-0,4$ \\
\hline $\begin{array}{c}\text { Fluído } \\
\text { supercrítico }\end{array}$ & $0,2-0,5$ & $(1-3) 10^{-4}$ & $(0,7) 10^{-3}$ \\
Líquido & $0,6-1,6$ & $(0,2-3,0) 10^{-2}$ & $(0,2-2,0) 10^{-5}$ \\
\hline \multicolumn{4}{c}{ Adaptado de STAHL } \\
\end{tabular}

Um fluído supercrítico possui baixos valores de viscosidade semelhantes a um gás; densidade (as maiores variações ocorrem nas proximidades do ponto crítico, onde a compressibilidade do solvente é maior), dissolução de solutos e poder de solvatação como um líquido, o que reforça o poder de solubilização da substância nesse estado;, ${ }^{9,3}$ além disso a difusão é intermediária entre gases e líquidos, variando com a sua densidade. Sob tais condições, o volume molar é o mesmo, quer a forma original tenha sido líquido ou gás. Assim, o dióxido de carbono, por exemplo, apolar em condições normais de temperatura e pressão, em elevadas pressões, apresenta constante dielétrica equivalente a substâncias de maior polaridade em condições normais de temperatura e pressão. Em contrapartida, a água, considerada como substância altamente polar em condições normais de temperatura e pressão apresenta constante dielétrica próxima de zero em elevadas temperaturas e pressões.

Existe uma série de substâncias que podem ser usadas como fluido supercrítico. Na Tabela 1.2 estão indicados algumas substâncias e seus pontos 
críticos.

Tabela 1.2 - Parâmetros físico - químicos de alguns compostos utilizados em seus estados supercríticos. ${ }^{10}$

\begin{tabular}{|c|c|c|c|c|}
\hline Fluido & $\begin{array}{l}\text { Massa } \\
\text { Molecular } \\
\left(\text { g.mol }{ }^{-1}\right)\end{array}$ & $\begin{array}{l}\text { Temperatura } \\
\text { crítica }\left({ }^{\circ} \mathrm{C}\right)\end{array}$ & $\begin{array}{c}\text { Pressão } \\
\text { crítica (atm) }\end{array}$ & $\begin{array}{c}\text { Densidade } \\
\text { crítica }\left(\mathrm{g} \cdot \mathrm{cm}^{-3}\right)\end{array}$ \\
\hline $\begin{array}{c}\text { Dióxido de } \\
\text { Carbono }\left(\mathrm{CO}_{2}\right)\end{array}$ & 44,01 & 30,95 & 72,9 & 0,47 \\
\hline Água $\left(\mathrm{H}_{2} \mathrm{O}\right)$ & 18,015 & 373,95 & 217,7 & 0,32 \\
\hline $\begin{array}{l}\text { Acetona } \\
\left(\mathrm{C}_{3} \mathrm{H}_{6} \mathrm{O}\right)\end{array}$ & 58,08 & 234,95 & 46,4 & 0,28 \\
\hline $\begin{array}{l}\text { Óxido Nitroso } \\
\qquad\left(\mathrm{N}_{2} \mathrm{O}\right)\end{array}$ & 44,013 & 36,5 & 71,8 & 0,45 \\
\hline $\begin{array}{c}\text { n-Pentano } \\
\left(\mathrm{C}_{5} \mathrm{H}_{12}\right)\end{array}$ & 72,15 & 196,6 & 33,3 & 0,23 \\
\hline $\begin{array}{l}\text { Hexafluoreto } \\
\text { de Enxofre } \\
\qquad\left(\mathrm{SF}_{6}\right)\end{array}$ & 146,06 & 45,5 & 37,1 & 0,74 \\
\hline Xenônio (Xe) & 131,29 & 16,6 & 58,4 & 1,10 \\
\hline $\begin{array}{l}\text { Metanol } \\
\left(\mathrm{CH}_{3} \mathrm{OH}\right)\end{array}$ & 32,04 & 239,5 & 78,9 & 0,27 \\
\hline $\begin{array}{c}\text { Etanol } \\
\left(\mathrm{C}_{2} \mathrm{H}_{5} \mathrm{OH}\right)\end{array}$ & 46,07 & 240,8 & 60,6 & 0,28 \\
\hline $\begin{array}{l}\text { Isopropanol } \\
\qquad\left(\mathrm{C}_{3} \mathrm{H}_{7} \mathrm{OH}\right)\end{array}$ & 60,1 & 235,3 & 47,0 & 0,27 \\
\hline
\end{tabular}


$\mathrm{Na}$ prática, um fluido supercrítico é apenas uma das possibilidades situadas entre os dois extremos. Entre os gases e líquidos existem várias outras possibilidades intermediárias, a depender da escolha da temperatura e da pressão. A Figura 1.2 ilustra esta situação, onde estão exemplificados o estado gasoso e o líquido como dois extremos e o fluido supercrítico como intermediário. Assim, iniciando-se com uma substância no estado líquido e aumentando-se sua temperatura a uma pressão constante, diminui-se de forma contínua sua densidade, tendendo ao estado gasoso. Se a pressão for suficientemente alta para não deixar a substância atingir o estado gasoso, esta estará em um estado intermediário entre os dois extremos (gás e líquido). Se nestas condições, a pressão e a temperatura (ambas) forem superiores à temperatura e à pressão críticas, a substância é dita estar no estado supercrítico e seu emprego como solvente de extração confere à técnica o nome de Extração com Fluido Supercrítico (SFE - "Supercritical Fluid Extraction"). Caso esteja, pelo menos uma delas (pressão ou temperatura), abaixo dos valores críticos, diz-se que a substância está no estado subcrítico. Esta condição entre o estado líquido e o supercrítico tem sido utilizada em várias técnicas modernas instrumentais, incluindo a extração (sub-SFE) e cromatografia (sub-FC) sub-críticas; extração acelerada com solventes (ASE, de Accelerated Solvent Extraction) ${ }^{11,12}$; e cromatografia com fluidez aumentada (EFC, de Enhanced Fluidity Chromatography), dentre outras possibilidades.

Figura 1.2 - Diagrama indicando o estado gasoso, líquido e o supecrítico de uma substância.

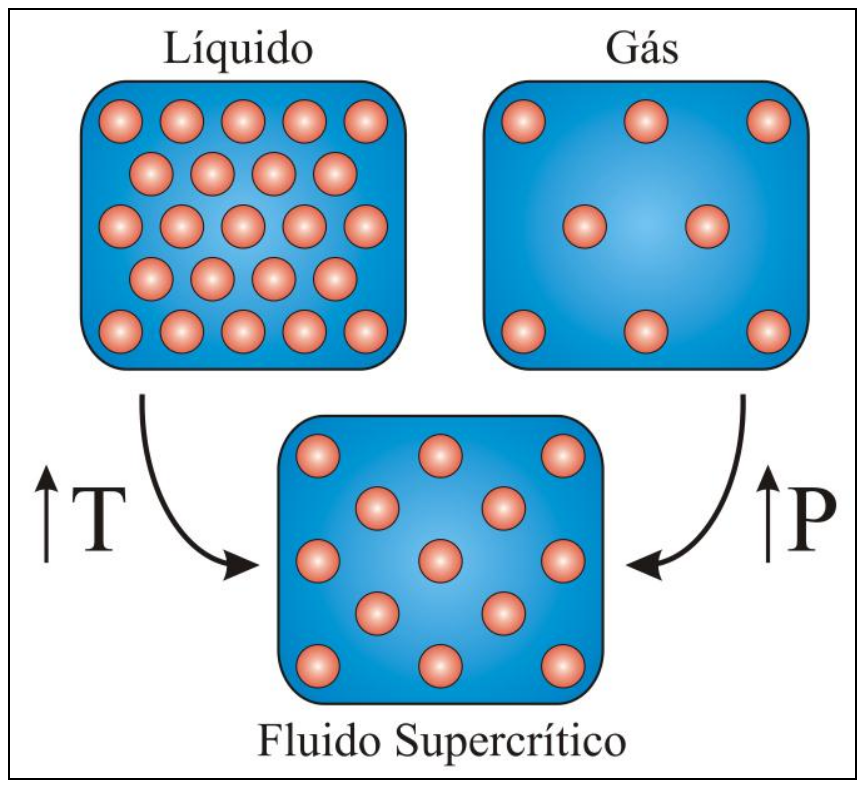


De forma análoga ao líquido, é possível alterarem-se as condições físicas de um gás de forma que se obtenham novas propriedades de interesse. $O$ aumento da pressão de um gás a uma temperatura constante tende a aumentar sua densidade em direção ao estado líquido. Assim, vários estados intermediários entre os dois extremos (gás e líquido) podem ser obtidos, incluindo o estado supercrítico (se a pressão e a temperatura - ambos - estiverem acima da crítica). Caso um dos parâmetros não esteja acima do crítico, outros estados intermediários entre o gasoso e o supercrítico podem ser obtidos como, por exemplo, o gás denso, o qual estaria com sua densidade modificada pela pressão, mas abaixo do estado crítico.

\subsection{Princípios da produção de biodiesel por fluido supercrítico}

A reação de transesterificação utilizando catalisadores, principalmente os convencionais, como bases ou ácidos, apresenta algumas desvantagens, tais como: dificuldade na separação das fases e do catalisador; complexidade na purificação dos produtos; impossibilidade de reutilização do catalisador e sensibilidade à água e aos ácidos graxos livres. No caso da reação de transesterificação com catálise básica, a água e os ácidos graxos podem reagir com o catalisador causando a saponificação dos ésteres e consumindo o catalisador, fazendo com que a eficiência da reação de transesterificação diminua. ${ }^{13,14}$

Uma alternativa a estes problemas é a reação de transesterificação nãocatalítica usada para sintetizar biodiesel através de óleos vegetais com álcool supercrítico. ${ }^{15,16}$

As reações utilizando fluido supercrítico aproveitam as propriedades físicas favoráveis dos fluidos no estado supercrítico para executar a reação. Portanto, o princípio do tratamento com fluído supercrítico está no efeito da relação entre a pressão e a temperatura sobre as propriedades termofísicas do solvente, tais como a constante dielétrica, a viscosidade, a densidade específica e a polaridade ${ }^{14}$ (Tabela 1.3). Por exemplo, o produto iônico dos álcoois, pode ser melhorado consideravelmente aumentando a pressão ${ }^{17} \mathrm{e}$, consequentemente, na reação de transesterificação do óleo vegetal empregando álcoois no estado supercrítico, além do álcool atuar como um reagente, ele atua também como um catalisador ácido. ${ }^{18}$ Adicionalmente, a constante dielétrica dos álcoois diminui fortemente devido a 
grande diferença de densidade ${ }^{19}$ chegando a um valor muito próximo a do óleo vegetal, causando mudanças na solvência ${ }^{20}$ e permitindo que ocorra uma mistura homogênea álcool/óleo vegetal em condições supercríticas, ${ }^{14}$ o que seria benéfico para o contato entre os reagentes e para a cinética da reação ser extremamente rápida.

Tabela 1.3 - Propriedades físico-químicas do metanol em condições normais e em condições supercríticas

\begin{tabular}{|c|c|c|}
\hline Propriedades & $\begin{array}{c}\text { Condições Normais } \\
\text { (25ㄷ, pressão } \\
\text { atmosférica) }\end{array}$ & $\begin{array}{c}\text { Condições } \\
\text { Supercríticas }(250 \text { ㅇ, } \\
200 \text { bar })\end{array}$ \\
\hline Densidade, $\mathrm{g} \cdot \mathrm{cm}^{-3}$ & 0,7915 & 0,2720 \\
\hline Produto lônico $\left(\log K_{w}\right)$ & $-0,77$ & Não disponível \\
\hline Constante dielétrica & 32,6 & 7,2 \\
\hline Viscosidade $\mathrm{g} \cdot \mathrm{cm}^{-1} \cdot \mathrm{s}^{-1}$ & 0,0054 & 0,00058 \\
\hline $\begin{array}{c}\text { Número de ligações de } \\
\text { hidrogênio }\end{array}$ & 1,93 & $<0,7$ \\
\hline $\begin{array}{c}\text { Parâmetro de } \\
\text { solubilidade }(\mathrm{MPa})^{0,5}\end{array}$ & 7,1 & 4,1 \\
\hline
\end{tabular}

\section{Objetivos Específicos}

Alguns trabalhos podem ser encontrados na literatura no sentido do desenvolvimento de processos contínuos utilizando álcoois supercríticos. ${ }^{23,24}$ Porém, os trabalhos envolvendo etanol em processos de batelada, em condições supercríticas, ainda são pouco explorados na literatura.

Neste sentido, o desenvolvimento de projetos de cunhos científico e tecnológico envolvendo etanol é vital para o país de modo a gerar informações que viabilizem tomadas de decisões mais seguras no que se refere à efetiva 
implementação da tecnologia de produção de biodiesel no Brasil. As desvantagens da rota de produção de biodiesel atualmente empregada, e as vantagens da tecnologia que usa reação em meio supercrítico, motivam o presente trabalho que poderá contribuir para a obtenção de informações mais detalhadas sobre possíveis melhorias que podem ser introduzidas nas etapas da reação de transesterificação etílica. Neste contexto, visando à produção de biodiesel por meio de etanol pressurizado, é de extrema importância que uma instrumentação adequada seja desenvolvida garantindo que o procedimento ocorra com segurança, visto serem necessárias altas pressões e temperaturas. Esta parte do trabalho, portanto, descreve o desenvolvimento do aparato experimental utilizado para realização das reações de transesterificação supercrítica realizadas neste trabalho.

\section{Experimental}

\subsection{Montagem do aparato experimental para realização da síntese do biodiesel}

Um aparato experimental prévio "home made" (Figura 1.3) foi desenvolvido envolvendo os seguintes elementos principais:

- Um reservatório de solvente. Este reservatório servia para armazenamento dos solventes empregados nos experimentos (metanol ou etanol);

- Uma bomba Seringa modelo 8500 (Varian, Palo Alto, USA). A bomba exercia o objetivo de enviar o solvente para a zona de reação. Bombas do tipo seringa encaixam perfeitamente para esse sistema, pois possuem um cilindro interno conectado a um esquema de controle automático da pressão;

- Uma válvula (válvula 1 na Figura 1.3) tipo agulha, que permitia uma abertura gradual e, consequentemente, uma regulagem do fluxo de solvente que alimentava a cela reacional;

- Um forno de um cromatógrafo gasoso modelo 5890 (Hewlett Packard, Avondale, USA). Este forno possui controlador e indicador de temperatura e é dotado de resistências internas responsável pelo aquecimento do interior do forno até a temperatura desejada para uma dada condição experimental;

- Uma cela reacional. Esta cela era de aço inox 316 com capacidade para $30 \mathrm{~mL}$ e 4,6 mm de diâmetro interno e possuía um tampa superior com conecção para a entrada do solvente e a uma tampa inferior com conecção para a saída da amostra em direção ao sistema de resfriamento, para posterior coleta. Como nesta cela reacional a amostra entrava em contato direto com a vedação, devido ao 
formato da cela, foi necessário que na fabricação dos anéis de vedação das tampas fossem utilizados anéis de PTFE (politetrafluoretileno), que apresenta-se como um material inerte;

Figura 1.3 - Diagrama esquemático do aparato experimental prévio desenvolvido.

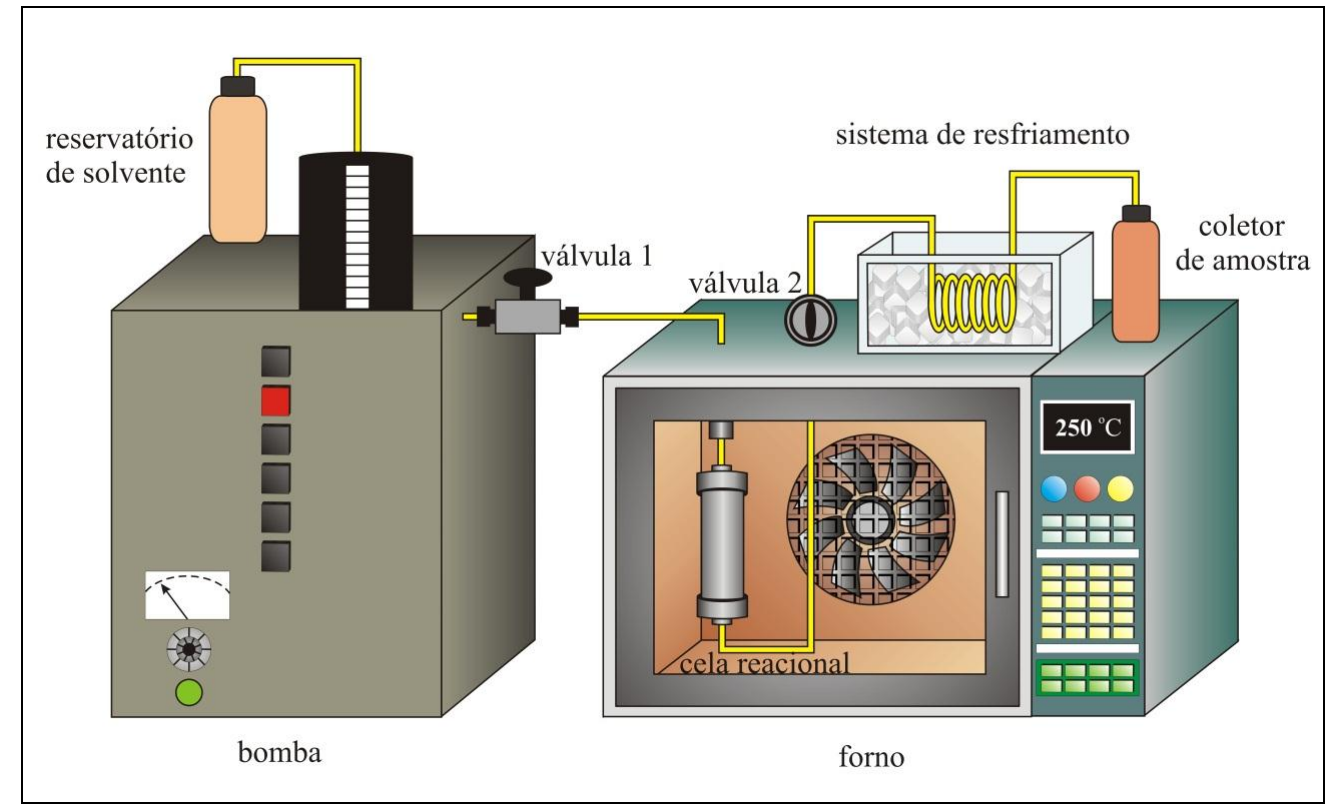

- Uma válvula abre-fecha (válvula 2 na Figura 1.3). A função desta válvula era permitir o fluxo da amostra em direção ao sistema de resfriamento. Foi inserida entre a cela reacional e o sistema de resfriamento, em posição exterior ao forno;

- Um sistema de resfriamento. Este sistema consistia de uma caixa térmica com um banho de gelo, com o intuito de diminuir a temperatura da amostra para posterior amostragem;

- Um coletor de amostra.

Alguns testes foram realizados na unidade desenvolvida, variando-se as temperaturas de 200 a $450^{\circ} \mathrm{C}$ (em um intervalo temperatura de $50^{\circ} \mathrm{C}$ ) e anotando-se as mudanças de pressão que variou em um intervalo de 60 a $450 \mathrm{~atm}$. Essas temperaturas foram avaliadas por estarem logo abaixo e bem acima da temperatura crítica do etanol, que seria utilizado nas reações de transesterificação do óleo de soja, objeto de estudo deste trabalho de doutorado.

Neste trabalho foi utilizado o modo estático e dois procedimentos experimentais foram adotados para os testes. Estes consistiam de forma resumida como descritos a seguir: 
No primeiro procedimento primeiramente adicionava-se o óleo dentro da cela de reação. Em seguida, ajustava-se a temperatura do forno e após a temperatura estabelecida ser atingida, abria-se a válvula agulha e a bomba enviava o solvente para dentro da cela reacional. Após o volume de solvente requerido ser enviado para dentro da cela e o sistema estar estabilizado, o sistema foi deixado operar durante o tempo estabelecido para cada reação. O tempo de estabilização do sistema era de aproximadamente 3 minutos. Durante a reação a válvula 1 (figura 1.3) permanecia aberta e a válvula 2 (Figura 1.3), era conservada fechada. Após o término do tempo estabelecido para a reação, a temperatura do forno era reduzida para $30^{\circ} \mathrm{C}$ e abria-se a válvula 2 (Figura 1.3) para que o fluxo de solvente arrastasse a amostra para o resfriamento. Logo após a amostra ser coletada, as válvulas eram fechadas e a cela retirada para limpeza. A seguir, a amostra coletada era então separada para posterior purificação e análise.

No segundo procedimento carregava-se a cela reacional com o óleo e o álcool (portanto sem o uso da bomba que neste caso apenas servia para indicar a pressão). Em seguida, ajustava-se a temperatura do forno e após a temperatura estabelecida ser atingida iniciava-se a contagem do tempo. O tempo de estabilização do sistema levava cerca de 3 minutos. Durante a reação a válvula 1 (Figura 1.3) permanecia aberta e a válvula 2 (Figura 1.3), era conservada fechada. Após o término do tempo estabelecido para a reação, a temperatura do forno era reduzida para $30^{\circ} \mathrm{C}$ e abria-se a válvula 2 (Figura 1.3) para que o fluxo de solvente arrastasse a amostra para o resfriamento. A redução gradativa da pressão ocorria por meio da diminuição da temperatura do forno. Logo após a amostra ser coletada, as válvulas eram fechadas e a cela retirada para limpeza. A seguir, a amostra coletada era então separada para posterior purificação e análise.

Como resultados similares foram obtidos para ambos os procedimentos, concluiu-se que não seria necessário o uso da bomba, visto que a presença desta implicava em maior gasto energético.

Os anéis de vedação da cela de reação de PTFE apresentaram deformações e, consequentemente, ocorreram vazamentos na cela de reação em temperaturas superiores a $200 \stackrel{\circ}{\circ}$ e pressões superiores a $400 \mathrm{~atm}$, sendo necessário o desenvolvimento de novos anéis de vedação com material que suportasse maiores temperaturas. Para que fosse utilizado outro material, seria também necessário o desenvolvimento de uma nova cela de reação em que a 
vedação não entrasse em contato com a solução, pois alguns materiais como o cobre podem servir de catalisador da reação de transesterificação. Portanto, uma nova cela de reação foi projetada juntamente com anéis de vedação de cobre.

Quanto ao sistema de resfriamento este não foi bem sucedido, visto que a ocorria constante entupimento das tubulações e da válvula 2 (Figura 1.3) durante o resfriamento. Em diversos experimentos, o sistema precisou ser desmontado para limpeza de válvula de controle e das linhas do memo. Portanto, não foi viável a utilização de um sistema "on-line" de resfriamento.

Uma evolução desse sistema é ilustrado na figura 1.4. O aparato experimental construído consiste de um reator em batelada para operar em condições sub e supercríticas. A unidade utilizada é provida de uma cela de reação tubular, um sistema de aquecimento, conjuntamente com um manômetro, além de um sistema de resfriamento.

Figura 1.4 - Diagrama esquemático do aparato experimental desenvolvido após modificações.

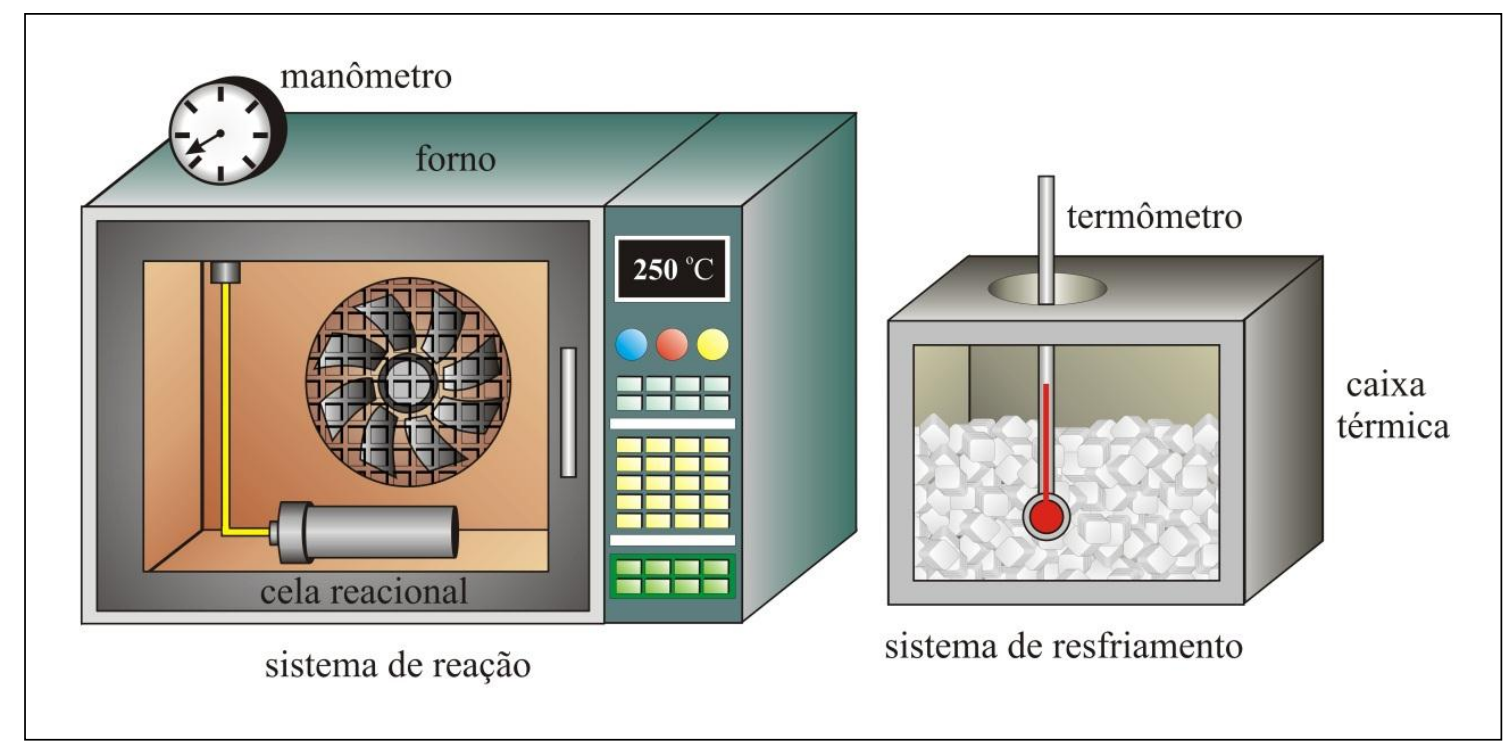

\subsubsection{A cela reacional}

A cela reacional foi manufaturada em aço inox $316 \mathrm{com}$ capacidade de $10,5 \mathrm{~mL}$, com $10 \mathrm{~mm}$ de diâmetro interno, $120 \mathrm{~mm}$ de altura e abertura com rosca na parte superior. A tampa da cela de reação possui uma conecção (fêmea 1/8"), para união com um manômetro, indicado para aferir a pressão durante a reação. $\mathrm{O}$ aço 316 foi adotado neste experimento por exibir resistência à corrosão e à tração além 
de apresentar capacidade de manter a integridade mecânica em temperaturas extremamente altas (510 ํㅡ em ambientes ácidos) ou muito baixas.

Para finalizar a montagem da cela de reação foi necessário aquisição de tubos de cobre, destinados à fabricação de anéis de vedação com $15 \mathrm{~mm}$ de diâmetro externo, $10 \mathrm{~mm}$ de diâmetro interno e $1,5 \mathrm{~mm}$ de espessura. $O$ cobre foi adotado, por ser altamente resistente a pressões e temperaturas (até $1100^{\circ} \mathrm{C}$ ) além de possui maior $\left(1,7 \times 10^{-5} \stackrel{\circ}{\circ} \mathrm{C}^{-1}\right)$ coeficiente de dilatação do que o aço $\left(1,1 \times 10^{-5}{ }^{\circ} \mathrm{C}^{-1}\right)$, promovendo uma melhor vedação durante o aquecimento. A Figura 1.5 apresenta 0 desenho esquemático do anel de cobre e a Figura 1.6 mostra o desenho esquemático da cela de reação completa.

Figura 1.5 - Desenho esquemático do anel de cobre utilizado para vedação da cela de reação.

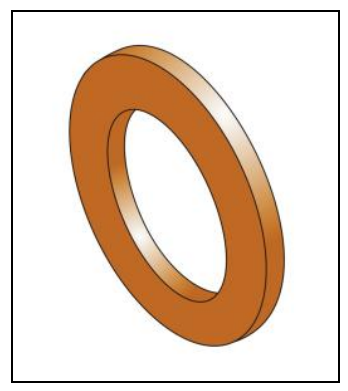

Figura 1.6 - Desenho esquemático da cela de reação completa com visualização de corte da cela de reação e cela de reação inteira.

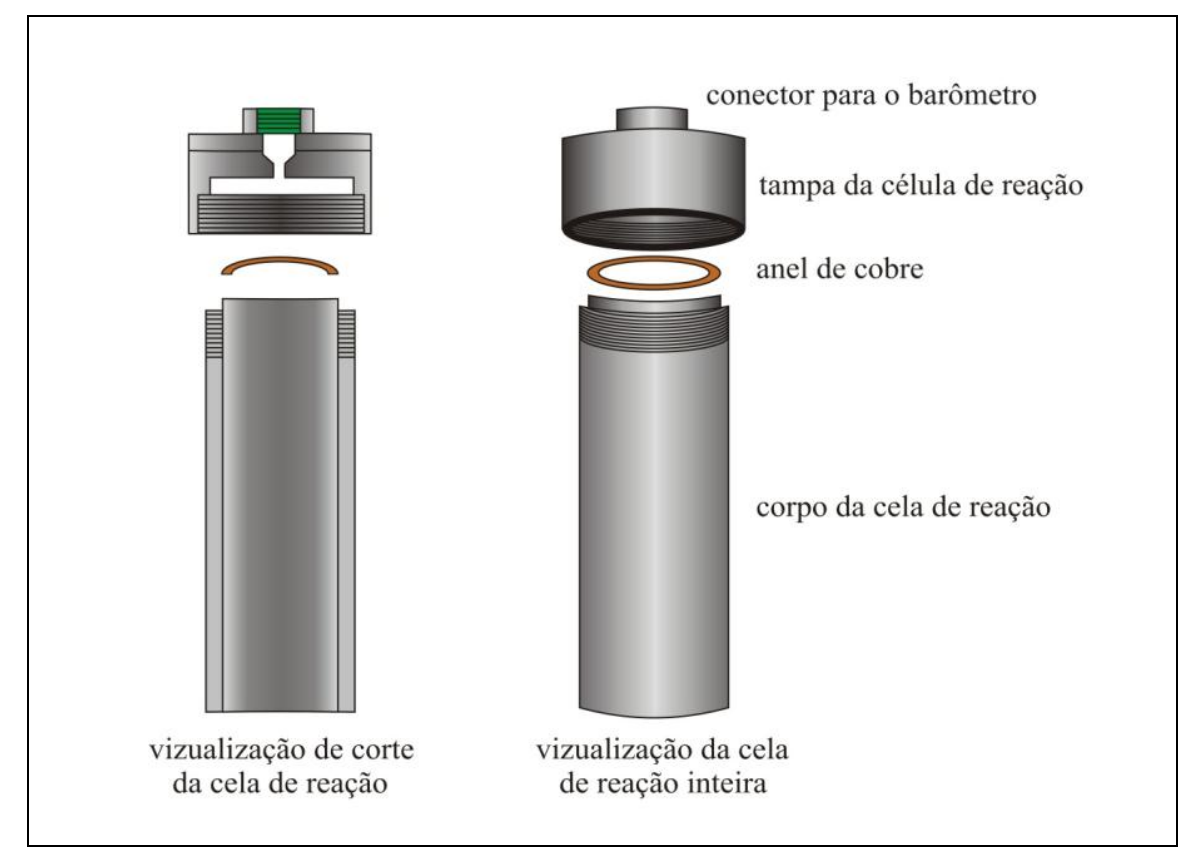




\subsubsection{O sistema de aquecimento}

O sistema de aquecimento no reator foi realizado por meio de um forno, já existente no Laboratório de Cromatografia do Instituto de Química de São Carlos, no qual a temperatura máxima admissível é de $450{ }^{\circ} \mathrm{C}$. As temperaturas indicadas no forno apresentaram uma variação de $\pm 1 \stackrel{\circ}{ } \mathrm{C}$. Esta variação foi medida adicionandose um termômetro no forno e fazendo a média de três medidas experimentais.

Externamente ao forno, porém ligado a parte superior da cela de reação, foi fixado um manômetro (0-1000 bar) (SWAGELOK, Detroit, EUA) por meio de 0,50 cm de tubulações $1 / 16$ ". As pressões medidas apresentaram uma variação de \pm 5 bar. Esta variação é a média de três medidas experimentais. O sistema mantinha-se interligado ao controle de pressão do reator durante todo o período de batelada.

\subsubsection{O sistema de resfriamento}

O sistema para resfriamento, desenvolvido com o objetivo de diminuir a temperatura da cela de reação para posterior amostragem, foi construído de maneira "off-line". Este sistema contempla uma caixa térmica (ISOESTE, Anápolis, Brasil) e um termômetro (INCOTERM, Porto Alegre, Brasil). A caixa térmica era preenchida com gelo e água até atingir a temperatura de $-5^{\circ} \mathrm{C}$, pois nessa temperatura garantiase que a reação havia sido encerrada, e que nenhum dos produtos ou sub-produtos fossem congelados.

\section{Resultados e Discussão}

\subsection{Validação da Unidade Experimental}

Testes preliminares foram realizados na unidade experimental final utilizada para verificar a estanqueidade das conecções do reator, com o forno aquecido. Os testes foram realizados primeiramente com água e logo após com etanol pressurizados em temperaturas de 200 a $450{ }^{\circ} \mathrm{C}$ (em um intervalo temperatura de $50 \stackrel{\circ}{\circ}$ ) anotando-se as pressões (a maior pressão anotada foi de 450 atm) e verificando se ocorria variações nestas, ou diferença do volume inicial inseridos na cela de reação, indicando o vazamento em algum ponto do reator. Nenhuma alteração foi observada.

Portanto, o aparato desenvolvido permite realizar reações em temperaturas de até $450 \stackrel{\circ}{\circ}$ e pressões de até 450 atm. Consequentemente, a obtenção de biodiesel com etanol pressurizado não deveria apresentar problemas com vazamentos no reator. Após os testes de vazão, procedeu-se à consecução dos 
experimentos de produção de biodiesel na unidade desenvolvida, estudo das reações e análise dos rendimentos por meio dos produtos obtidos.

\section{Conclusão}

Esta etapa do trabalho teve por foco o desenvolvimento de um aparato experimental para o estudo da produção em batelada de biodiesel de óleo de soja etílico pressurizado, observando-se as variáveis envolvidas. Como os testes demonstram que o aparato desenvolvido replicou dados de investigações nas condições estudadas, a unidade experimental possibilita a investigação das variáveis do processo de forma segura e reprodutível.

Uma vantagem é a utilização desse sistema para diversas reações em que seja necessário o uso de altas pressões e temperaturas, pois esse sistema permite, com algumas modificações, a inclusão de acessórios e celas de volumes variáveis, dependendo da finalidade de emprego.

Além disso, o sistema apresentou-se significativamente versátil, por ser simples de operar, de baixo custo para construir-se, sendo o último um dos maiores problemas concernentes à implantação industrial desta técnica: o seu alto custo de investimento.

\section{Sugestões para trabalhos futuros}

Diante da viabilidade do sistema desenvolvido, sugere-se para trabalhos futuros os seguintes temas:

- Investigar tecnologias acopladas na saída do reator para permitir a separação imediata do glicerol do meio reacional e;

- Construir este reator em uma escala maior que o nível de bancada para a avaliação de possibilidade de suas aplicações industriais.

\section{Referências}

1TAYLOR, L. T. Supercritical fluid extraction: techniques in analytical chemistry. New York: John Wiley, 1996. 181 p.

2 HANNAY, J. B.; HOGART, J. On the solubility of solids in gases. Proceedings of The Royal Society of London , v. 29, n. 2, p. 324-326, 1879.

3 McHUGH, M. A; KRUKONIS, V. J. Supercritical fluids extraction: principles and practice. Boston: Butterworth, 1986. 507 p. 
4 RIZVI, S. S. H. Supercritical fluid extraction: fundamental principles and modeling methods. Food Technology, v. 40, n. 6, p. 55-64, 1986.

5 RADOSZ, M.; RONALD, L. C.; PRAUSNITZ, J. M. Phase equilibria in supercritical propane systems for separation of continuous oil mixtures. Industrial \& Engineering Chemistry Research, v. 26, n. 4, p. 731-737, 1987.

6 LANCAS, F. M. Extração com fluido supercrítico: quo vadis? Revista Analytica, v. 2, p. 30-37, 2002.

7 FREITAS, L. S.; OLIVEIRA, J. V.; DARIVA, C.; JACQUES, R. A.; CARAMAO, E. B. Extraction of grape seed oil using compressed carbon dioxide and propane: extraction yields and characterization of free glycerol compounds. Journal of Agricultural and Food Chemistry, v. 56, n. 8, p. 2558-2564, 2008.

8 STAHL, E.; QUIRIN, K. W.; GERARD, D. Dense gases for extraction and refining. New York: Spring-Verlag, 1988. 176 p.

9 ARAI, Y.; SAKO, T.; TAKEBAYASHI, Y. Supercritical fluids: molecular interactions, physical properties, and new applications. Berlin: Springer, 2002. 446 p.

10 LATER, D. W.; RICHTER, B. E.; ANDERSEN, M. R. Capillary SFC, an emerging technology in perspective. LC-GC, v. 4, p. 992-1003, 1986.

11 PINTO, JAIR SEBASTIÃO DA SILVA. Uso da água no estado subcrítico como uma ferramenta analítica ambientalmente correta. 2002. $158 \mathrm{f}$. Tese (Doutorado em Ciências - Química Analítica) - Instituto de Química de São Carlos, Universidade de São Paulo, São Carlos, 2002.

12 ASSIS, L. M.; PINTO, J. S. S.; LANÇAS, F. M. Comparison among different extraction methods (PFE, SFE, Sonication, SOXHLET) for the isolation of organic compounds from coal. . The Journal of Microcolumn Separations, v. 12, n. 5, p. 292-301, 2000.

13 HAWASH, S.; KAMAL, N.; ZAHER, F.; KENAWI, O.; EL DIWANI, G. Biodiesel fuel from Jatropha oil via non-catalytic supercritical methanol transesterification. Fuel, v. 88 , n. 3, p. 579-582. 2009.

14 KUSDIANA, D. SAKA, S. Effects of water on biodiesel fuel production by supercritical methanol treatment. Bioresource Technology, v. 91, n. 3, p. 289-295. 2004.

15 WEN, D.; JIANG, H.; ZHANG, K. Supercritical fluids technology for clean biofuel production. Progress in Natural Science, v. 19, n. 3, p. 273-284, 2009.

16 MADRAS, G.; KOLLURU, C.; KUMAR, R. Synthesis of biodiesel in supercritical fluids. Fuel, v. 83, n. 14-15, p. 2029-2033, 2004. 
17 BROLL, D.; KAUL, C.; KRÄMER, A.; KRAMMER, P.; RICHTER, T.; JUNG, M.; VOGEL, H.; ZEHNER, P. Chemistry in supercritical water. Angewandte Chemie International Edition, v. 38, n. 20, p. 2998-3014, 1999.

18 SAKA, S.; KUSDIANA, D. Biodiesel fuel from rapeseed oil as prepared in supercritical methanol. Fuel, v. 80, n. 2, p. 225-231, 2001.

19 NOYORI, R. Supercritical Fluids: Introduction. Chemical Reviews, v. 99, n. 2, p. 353-354, 1999.

20 TUCKER, S. C. Solvent density inhomogeneities in supercritical fluids. Chemical Reviews, v. 99, n. 2, p. 391-418, 1999.

21 DEMIRBAS, A. Biodiesel from vegetable oils via transesterification in supercritical methanol. Energy: Conversion \& Management, v. 43, n. 17, p. 2349-2356, 2002.

22 CAO W.; HAN, H.; ZHANG, J. Preparation of biodiesel from soybean oil using supercritical methanol and co-solvent. Fuel, v. 84, n. 4, p. 347-351, 2005.

$23 \mathrm{HE}, \mathrm{H} . ;$ TAO, W.; ZHU, S. Continuous production of biodiesel from vegetable oil using supercritical methanol process. Fuel, v. 86, n. 3, p. 442-447, 2007.

24 ANITESCU, G.; DESHPANDE, A.; TAVLARIDES, L. L. Integrated techonology for supercritical biodiesel production and power cogeneration. Energy \& Fuels, v. 22, n. 2, p. 1391-1399, 2008. 


\section{CAPÍTULO II}

\section{Produção de biodiesel etílico e metílico em reator supercrítico utilizando análise multivariada}




\section{Introdução}

O biodiesel é definido pela Resolução 42 de 24/11/2004 da Agência Nacional do Petróleo, Gás Natural e Biocombustíveis - ANP como um combustível composto de alquilésteres de ácidos graxos de cadeia longa, derivados de óleos vegetais ou de gorduras animais. ${ }^{1}$

A transesterificação ou alcóolise tem sido o método mais adequado para a produção de biodiesel. ${ }^{2,3} \mathrm{~A}$ transesterificação é uma reação orgânica onde um éster é transformado em outro pela mudança na porção alcóxi. Na reação de transesterificação de óleos vegetais, os triglicerídeos reagem com um álcool, geralmente na presença de catalisador, produzindo uma mistura de ésteres e glicerina (co-produto da reação), como demonstrado na Figura 2.1, onde o álcool é o agente transesterificante. A reação de transesterificação é composta de três reações consecutivas e reversíveis (i a iii), nas quais são formados diglicerídeos e monoglicerídeos como intermediários. ${ }^{4}$ Observa-se na Figura 2.1 em decorrência da estequiometria da reação, que teoricamente a partir de um mol de triglicerídeo são obtidos três mols de ésteres. Porém, por se tratar de uma reação reversível, para aumentar o rendimento dos ésteres, a razão entre o álcool e triglicerídeo necessita ser mais elevada que a estequiométrica (3:1) a fim de deslocar o equilíbrio para o lado dos produtos. ${ }^{5}$

\subsection{Constituição química das matérias-primas}

As fontes de insumos para a reação de transesterificação compreendem os seguintes componentes: uma fonte de ácidos graxos de cadeia longa, um álcool e, frequentemente, um catalisador. Qualquer lipídio de origem animal ou vegetal pode ser considerado uma fonte de ácido graxo para a produção de biodiesel.

Os óleos vegetais são basicamente compostos de triglicerídeos, que são triéster derivado da glicerina (Figura 2.2), enquanto que as gorduras animais são ricas em ácidos graxos livres (Figura 2.2). ${ }^{6}$

Os ácidos graxos são formados por uma cadeia hidrocarbônica não ramificada, tendo uma das extremidades polares, uma constituída pelo grupo metílico $\mathrm{CH}_{3}$ e outra a que está ligada a função ácido $\mathrm{COOH}$. Os ácidos graxos saturados quando apresentam 10 ou mais carbonos são sólidos à temperatura ambiente, devido ao ponto de fusão aumentar com o aumento do número de átomos de carbono na cadeia. Os ácidos graxos insaturados apresentam um ponto de fusão mais baixo e, regra geral, são líquidos à temperatura ambiente. 
Figura 2.1- Esquema das reações envolvidas na transesterificação de triglicerídeos, onde R é uma cadeia hidrocarbônica.

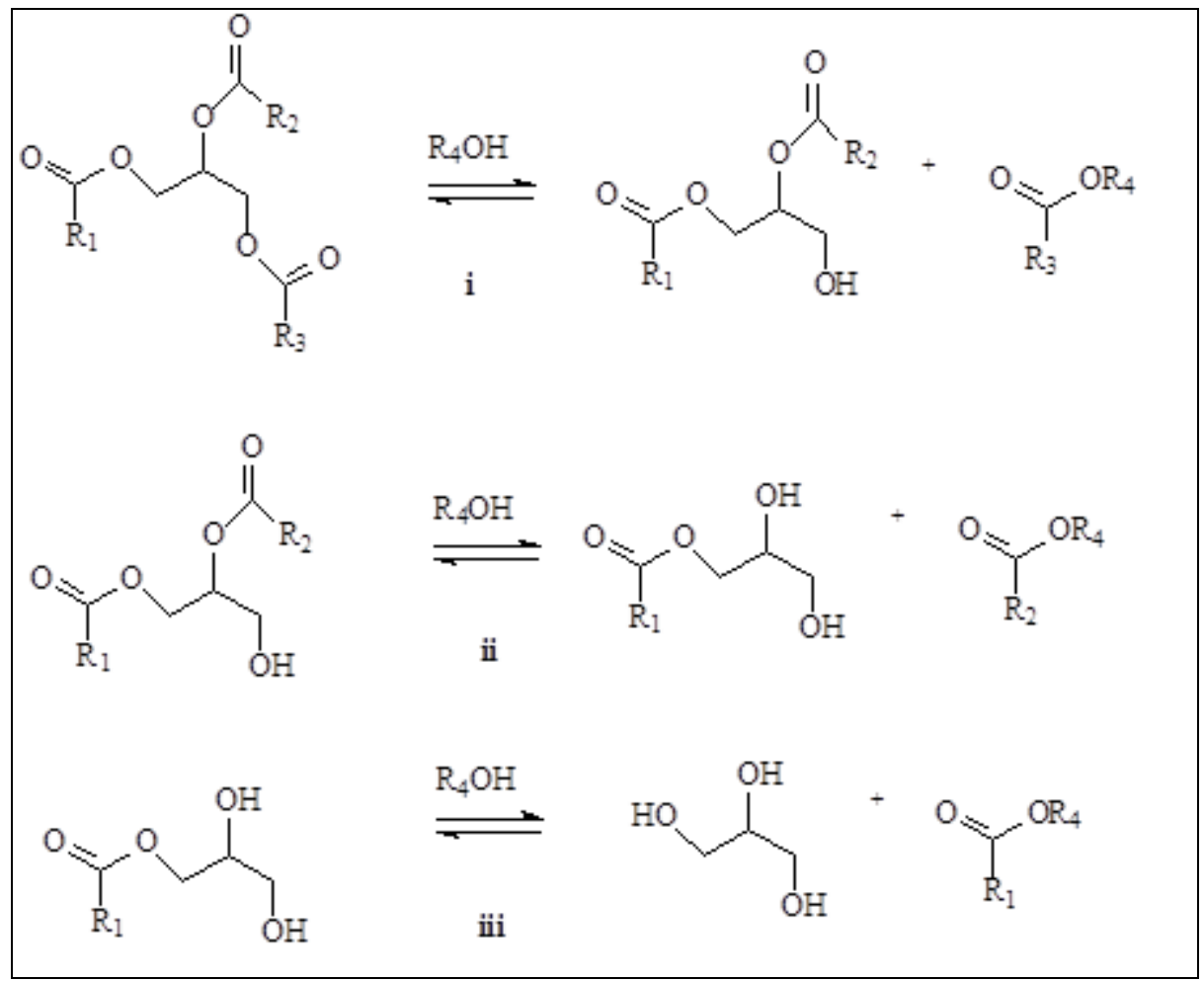

Figura 2.2 - Esquema das estruturas das moléculas do glicerol, ácido graxo, monoglicerídeo, diglicerídeo e triglicerídeo, onde R é uma cadeia hidrocarbônica.<smiles>[R]C(=O)O</smiles>

Ácido graxo
Glicerol<smiles>[R4]C(=O)OCC(O)CO</smiles>

1 - Monoglicerídeo<smiles>[R4]C(=O)OCC(CO)OC([R4])=O</smiles>

1,2 - Diglicerídeo<smiles>[R4]C(=O)OCC(COC([R4])=O)OC([R4])=O</smiles>

Triglicerídeo 
Os triglicerídeos são constituídos por três cadeia de ácidos graxos ligados a uma molécula de glicerol. Cerca de $90 \%$ dos óleos vegetais produzidos no mundo são formados por triglicerídeos de ácidos graxos de cadeia longa, que varia de 16 a 20 átomos de carbono, tendo como principais constituintes os ácidos palmítico $\left(\mathrm{C}_{16} \mathrm{H}_{32} \mathrm{O}_{2}\right)$, esteárico $\left(\mathrm{C}_{18} \mathrm{H}_{36} \mathrm{O}_{2}\right)$, oleico $\left(\mathrm{C}_{18} \mathrm{H}_{34} \mathrm{O}_{2}\right)$ e linoleico $\left(\mathrm{C}_{18} \mathrm{H}_{32} \mathrm{O}_{2}\right){ }^{7}$

No Brasil, as principais opções de óleos vegetais que podem ser utilizados como matérias-primas para fabricação de biodiesel são: o óleo de amendoim, girassol, canola, soja, palma, dendê, babaçu, macaúba e a oiticina. ${ }^{8-11}$ Vale salientar que a soja ocupa uma posição de destaque por apresentar uma cultura já estabelecida.

O uso de óleos vegetais não alimentícios também tem sido proposto para produção de biodiesel. Exemplos são o uso da mamona (Ricinnus communis), do pinhão manso (Jatropha curcas), dentre outras. Porém, essas plantas apresentam toxicidade devido à presença de compostos como a ricina no óleo de mamona, ${ }^{12,13} \mathrm{a}$ curcina e ésteres forbol no óleo de pinhão manso. ${ }^{14}$

No que se refere à mamona, seu uso foi largamente incentivado no Brasil para a produção de biodiesel. Porém, após ocorrer um grande incentivo para a produção desta oleaginosa, viu-se que tanto o processo de produção do biodiesel era difícil quanto a qualidade do combustível obtido não era adequada. Esta característica deve-se ao fato de o óleo de mamona apresentar cerca de $90 \%$ de sua composição de triricinoleína (Figura 2.3). O ácido ricinoleico (ácido 12 - hidroxi9-cis-octadecenóico) por possuir um grupo hidroxila na cadeia carbônica promove uma maior viscosidade e densidade ao óleo e ao biodiesel, não atendendo às propriedades desejadas do biocombustível. ${ }^{15}$ Por outro lado, óleos ou gorduras muito insaturados (por exemplo, o óleo de tungue) ou pouco insaturados (por exemplo, o sebo de boi) também levam à produção de biodiesel com problemas de qualidade. No primeiro caso, o excesso de duplas ligações pode levar à polimerização pelo contato com o ar ou, quando aquecidos, à polimerização oxidativa do biodiesel, durante seu armazenamento ou uso. Já o excesso de cadeias completamente saturadas aumenta o ponto de fusão do combustível, o que limita o seu uso em regiões de clima temperado e frio.

Outras matérias-primas que têm sido apontadas para a obtenção de biodiesel são os materiais graxos residuais, tanto de origem doméstica quanto 
industrial (gorduras animais resultantes principalmente do abate de gado, aves, peixes e suínos). Essas gorduras são uma alternativa para o problema de equilíbrio

Figura 2.3 - Figura da estrutura da molécula da triricinoleína (triglicerídeo presente no óleo de mamona).

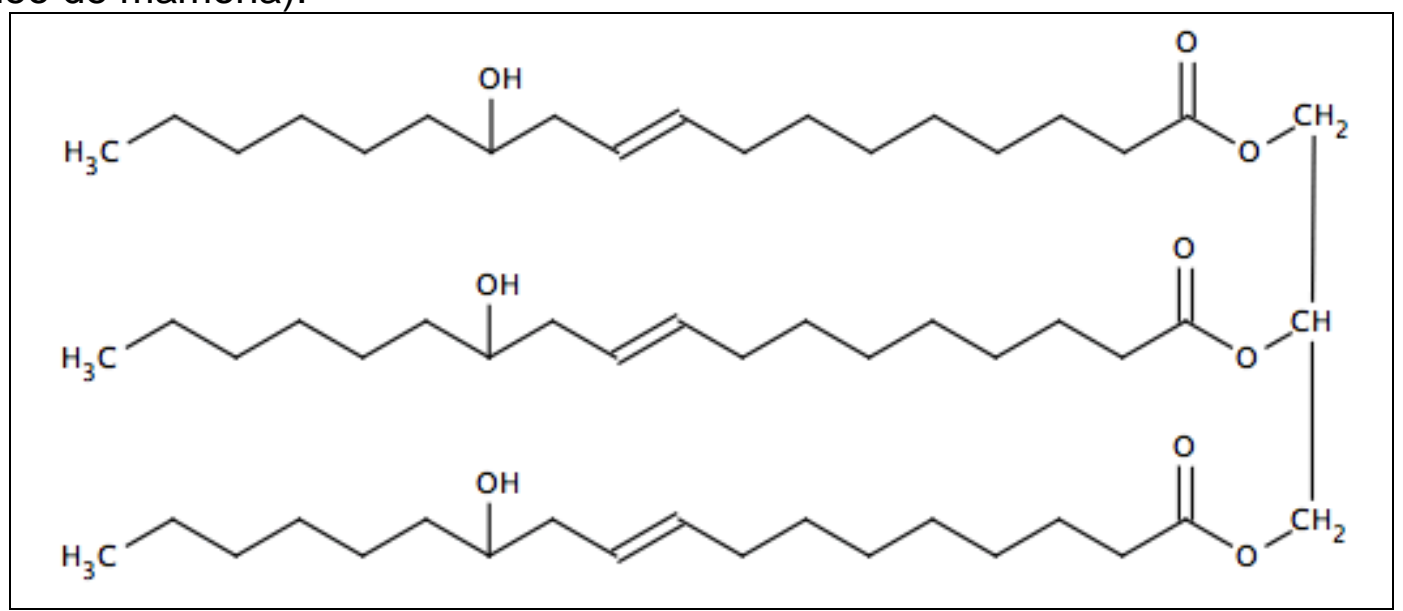

entre a produção de alimentos e energia, e apresentam um custo mais competitivo do biocombustível em relação aos combustíveis fósseis. Porém essas matériasprimas possuem alto teor de ácidos graxos saturados. Estes altos teores de ácidos graxos saturados determina o aumento do ponto de névoa e do ponto de entupimento de filtro a frio $^{16}$ além de impedir o seu uso direto em processos alcalinos tradicionais de obtenção de biodiesel, necessitando de processos prévios de purificação, o que pode muitas vezes inviabilizar economicamente o seu uso.

O cultivo de microalgas também é promissor para a produção de biocombustíveis. Além da alta produtividade, inúmeras outras vantagens podem ser apontadas, ${ }^{17}$ tais como, um ciclo de vida de poucos dias, permitindo colheitas contínuas e diminuindo as necessidades de logística de armazenagem necessárias para o caso de culturas anuais. No entanto, a produção industrial de óleos a partir de microalgas ainda apresenta uma série de problemas tecnológicos: ${ }^{18}$ existe sempre a possibilidade de ataque de cepas de algas ou outros micro-organismos selvagens não produtores de óleos, ou que o produzem em menor quantidade ou com composição indesejada; necessidade de se manter constante os diversos parâmetros de processo, tais como temperatura, pH e concentração dos nutrientes, pois a alteração desses parâmetros pode levar a uma queda acentuada na produção e mesmo a uma morte total do cultivo; os nutrientes necessários para o crescimento das algas, além do $\mathrm{CO} 2$, são bastante caros; após isolar as algas se deve extrair o 
óleo, sendo para isso necessário romper a parede celular das mesmas, não sendo possível utilizar os processos industriais usuais de extração; e, finalmente, o óleo produzido tem alto teor de água e de ácidos graxos livres, o que impede o seu uso direto em processos alcalinos tradicionais de obtenção de biodiesel. Tais dificuldades fazem com que o custo de produção de óleo a partir do cultivo de algas seja hoje até 20 vezes superior ao custo a partir da soja. ${ }^{18}$

Com relação ao álcool na reação de transesterificação para produção de biodiesel, o metanol $(\mathrm{CH} 3 \mathrm{OH})$, o etanol $(\mathrm{C} 2 \mathrm{H} 5 \mathrm{OH})$, o propanol $(\mathrm{C} 3 \mathrm{H} 7 \mathrm{OH})$ e o butanol $(\mathrm{C} 4 \mathrm{H} 9 \mathrm{OH})$ podem ser usados como matérias-primas. ${ }^{19}$

O metanol é o álcool predominantemente utilizado para a produção de biodiesel em termos mundiais. Esta predominância deve-se ao fato relacionado com o custo de produção que, em países como nos Estados Unidos, pode ser até $50 \%$ mais barato do que o etanol. Entretanto, o uso do metanol para o Brasil não é vantajoso, além de ser um álcool tóxico, venenoso e de origem fóssil (derivado do petróleo) aproximadamente $50 \%$ do metanol consumido no país é importado. Uma alternativa interessante seria a utilização do etanol obtido da cana-de-açúcar, que é 100\% renovável e garante maior segurança na manipulação devido a sua menor toxicidade. Destaca-se ainda que, no Brasil, existe uma maior disponibilidade do álcool de cana (grande produtor mundial de etanol), tornando importante a sua aplicação na produção de biodiesel; além disso, o emprego de tecnologia nacional já desenvolvida e um mercado consolidado minimizam o impacto de oscilações do mercado estrangeiro na economia nacional.

Tradicionalmente, a transesterificação é realizada empregando catalisadores homogêneos, ácidos ou básicos, sendo os principais exemplos os hidróxidos e alcóxidos de metais alcalinos e os ácidos sulfúrico, fosfórico, clorídrico e organossulfônicos. ${ }^{4} \mathrm{~A}$ catálise básica apresenta problemas operacionais quando 0 óleo possui altos teores de ácidos graxos e quando água está presente. Isto ocorre devido ao fato de poder ocorrer reação de saponificação, resultando na formação de sabões que, além de consumirem parte do catalisador durante sua formação, acabam gerando emulsões e levando a dificuldades na separação e purificação dos produtos da reação. Apesar da transesterificação empregando catalisadores ácidos minimizar tais inconvenientes, a cinética da reação é extremamente lenta. Por outro lado, em sistemas com alto teor de acidez livre e/ou elevado conteúdo de água, a catálise ácida pode ser empregada. ${ }^{5,20}$ Porém, as exigências de remoção de 
catalisador e de excessivas quantidades de energia empregadas, são as principais desvantagens de tal processo químico. ${ }^{21}$

Como alternativa aos catalisadores básicos e ácidos tradicionais, novas classes foram propostas, incluindo bases orgânicas, complexos metálicos, aluminossilicatos e óxidos metálicos. Os catalisadores heterogêneos vem sendo estudados como catalisadores da reação de transesterificação de triglicerídeos ${ }^{5}$, principalmente em virtude da facilidade de separação do catalisador do meio reacional e da possibilidade de reutilização deste catalisador, o que resulta em benefícios técnicos, econômicos e ambientais. Por outro lado, os sistemas de catálise heterogênea podem requerer maior tempo de reação, temperaturas mais elevadas, e plantas industriais mais sofisticadas, além de apresentarem problemas de transferência de massa, sobretudo em reações envolvendo moléculas de alto peso molecular. ${ }^{5}$

Em outra frente de ação para o desenvolvimento de catalisadores heterogêneos, encontram-se as enzimas. Tais biocatalisadores apresentam como principal aliado o fato de poderem ser produzidos a partir de rejeitos de agroindústrias. $^{21}$ Segundo MARCHETTI et al. ${ }^{22}$, além da possibilidade de regeneração e reutilização, os biocatalisadores apresentam facilidade de separação do meio reacional, estabilidade térmica maior e produtos de maior pureza. Por outro lado, o elevado custo de produção destes biocatalisadores ainda é o principal obstáculo para sua utilização na produção de biodiesel em larga escala. Da mesma forma, uma vez que as enzimas são compostas por proteínas, a temperatura do processo é limitada tipicamente a valores inferiores a $70-80^{\circ} \mathrm{C}$. Como resultado de tal fato, o tempo reacional para obter elevadas conversões do processo de produção de biodiesel é, geralmente, maior do que aquele que emprega catalisadores heterogêneos de origem química (argilas, óxidos, etc).

Uma alternativa aos problemas enfrentados pelas reações catalíticas são as reações de transesterificação não catalítica de óleos vegetais com álcool supercrítico, ou seja, álcool submetido a elevadas pressões e temperaturas. ${ }^{23} \mathrm{~A}$ principal vantagem deste método em relação ao método convencional é a ausência de procedimentos de remoção do catalisador e produtos saponificados após a reação, além da possibilidade de utilização de uma grande variedade de reagentes, bem como a ausência do pré-tratamento do óleo vegetal para eliminação de água e ácidos graxos livres, pois este método não é sensível a estes contaminantes. ${ }^{24} \mathrm{~A}$ 
eliminação destes procedimentos reduz consideravelmente os custos de uma planta de biodiesel, fazendo com que, do ponto de vista econômico, o processo de transesterificação com fluidos supercríticos possa competir com os processos tradicionais de transesterificação que usam catalisadores homogêneos ácidos ou básicos.

\subsection{Transesterificação em fluidos supercríticos}

Em virtude das vantagens citadas, várias pesquisas sobre a reação de transesterificação de óleos vegetais com álcool supercrítico vêm sendo desenvolvidas. ${ }^{25-27}$ Porém, as condições experimentais utilizadas para a síntese do biodiesel com álcool supercrítico são responsáveis pela grande desvantagem desse processo, pois são requeridos equipamentos que trabalhem à altas pressões e temperaturas, além do elevado consumo energético pelo qual não é viável para aplicação industrial. Em função disso, um dos grandes desafios é conseguir suavizar as condições reacionais deste processo não-catalítico.

Algumas tentativas descritas na literatura têm permitido amenizar a pressão, a temperatura, e o excesso necessário de álcool utilizado, embora esses resultados ainda não sejam drásticos ou altamente significativos. Esses trabalhos utilizaram dióxido de carbono $^{28}$ ou hexano ${ }^{23}$ como cossolvente na produção do biodiesel de soja.

Em trabalho publicado em 2008 por YIN et al. ${ }^{29}$ foram descritos resultados comparativos da transesterificação do óleo de soja com metanol em condições supercríticas e em condições subcríticas. Realizando a reação com uma relação metanol:óleo de $42: 1$ a uma temperatura de $350{ }^{\circ} \mathrm{C}$ e sob pressão de $20 \mathrm{Mpa}$ durante 10 min na ausência de catalisador, o rendimento do biodiesel atingiu 95\%, subindo para $98 \%$ após 60 min de reação.

HAWASH et al. ${ }^{30}$ descrevem os resultados da produção de biodiesel de Jatropha curcas (pinhão manso) pelo processo não-catalítico com metanol sob condições supercríticas. Esses autores obtiveram os ésteres desejados em 100\% de rendimento, após 4 min de reação usando uma relação molar álcool:óleo de $43: 1$ a $593 \mathrm{~K}$ e 8,4 MPa.

Em resumo, uma quantidade razoável de trabalhos empregando álcoois supercríticos na reação de transesterificação têm surgido na literatura. Porém, os trabalhos envolvendo etanol em processos de batelada, em condições supercríticas, 
ainda são pouco explorados na literatura e em geral os trabalhos são focados em diferentes oleaginosas existindo uma deficiência em explorar melhores condições para produção de biodiesel empregando-se álcool no estado supercrítico.

Para que as melhores condições sejam explorada de forma a otimizar o número de experimentos, planejamentos de experimentos podem ser desenvolvidos.

\subsection{Planejamento de experimentos}

O planejamento experimental tem como base a análise estatística e apresenta-se como uma ferramental econômica, por realizar poucos experimentos, usar de forma racional os reagentes, e permitir avaliar as interações entre variáveis avaliadas, as quais são ignoradas em processos de otimização univariada. ${ }^{31}$

As técnicas de planejamento de experimentos podem ser utilizadas nas etapas de projeto preliminar, projeto do produto e processo de fabricação, e na etapa de avaliação e melhoria. Nessas fases, muitas vezes, torna-se necessário analisar a influência de um ou mais fatores. Quando for avaliado apenas o efeito de um fator nas respostas do produto ou do processo de fabricação, recomenda-se utilizar a técnica do planejamento de experimentos completamente aleatórios. Por outro lado, quando torna-se importante investigar o efeito provocado nas respostas dos experimentos por dois ou mais fatores de controle e, cada um deles com dois ou mais níveis de regulagens, recomenda-se o uso de técnicas clássicas de planejamento como, por exemplo, técnicas de planejamento fatorial completo, fatorial fracionado ou experimentos com pontos centrais.

\subsubsection{Planejamento Fatorial}

O planejamento fatorial tem sido muito aplicado em pesquisas básicas e tecnológicas e é classificado como um método do tipo simultâneo, onde as variáveis de interesse que realmente apresentam influências significativas na resposta são avaliadas ao mesmo tempo.

Para realizar um estudo deste tipo, deve-se escolher as variáveis a serem estudadas e efetuarem-se experimentos em diferentes níveis destes fatores. De um modo geral, o planejamento fatorial pode ser representado por $b^{\alpha}$, onde a é o número de fatores e b é o número de níveis escolhidos. Em um estudo que tenha 3 fatores e 2 níveis $\left(2^{3}\right)$, o número total de experimentos é $8 .^{31}$

Nos planejamentos experimentais onde as variáveis são exploradas em 2 níveis, é comum codificá-los usando os sinais (+) e (-). A atribuição desses sinais 
aos níveis superiores ou inferiores é feita de forma arbitrária e não interfere na realização dos experimentos ou interpretação dos resultados, além de permitir esquematizar o planejamento na forma de matriz de planejamento. Os efeitos obtidos em cada um dos experimentos avaliados são, posteriormente, utilizados para gerar informações a respeito das tendências de cada fator estudado. Os efeitos são definidos como a mudança ocorrida na resposta quando se move do nível baixo (-) para o nível mais alto $(+) .{ }^{31}$

A abordagem experimental consiste em variar todas as variáveis ao mesmo tempo. A razão para isso é que variáveis podem se influenciar mutuamente e o valor ideal para uma delas pode depender do valor da outra. Este comportamento é chamado de interação entre variáveis que consiste em um fenômeno frequente, sendo que raramente observa-se situações em que duas variáveis atuam de forma independente.

\section{Objetivos específicos}

É clara a necessidade de amenizar ou minimizar os requerimentos energéticos da reação de transesterificação supercrítica, no sentido de minimizar as temperaturas e pressões envolvidas, assim como de diminuir as razões álcool:óleo para que os procedimentos em condições super ou subcríticas possam ganhar aplicabilidade e trazer para a realidade as "justificativas acadêmicas" de que são métodos superiores aos métodos químicos convencionais. Caso contrário, as pesquisas continuarão sendo desenvolvidas nos mesmos parâmetros, modificando somente a origem ou tipo dos óleos empregados, sem contribuir para as soluções necessárias.

Dessa maneira, esse trabalho trata da análise multivariada de produção de biodiesel por meio de fluidos pressurizados. Um planejamento fatorial $2^{3}$ foi usado para verificar o comportamento das variáveis presentes na reação de transesterificação do óleo de soja utilizando etanol pressurizado. Este trabalho também é justificado no contexto nacional por empregar etanol como álcool e óleo de soja, substratos estes em que o país é um dos líderes mundiais de produção e com tecnologia nacional já estabelecida e consolidada. Contudo, existe uma polêmica na escolha da rota tecnológica metílica e etílica que é a questão da relação consumo de álcool $x$ rendimento em biodiesel. Geralmente, é relatado que o consumo de metanol é menor quando comparado com o consumo de etanol para 
mesmo rendimento nas reações catalíticas de produção de biodiesel. Portanto neste trabalho explorou-se o uso do metanol e etanol como agentes esterificantes da reação, procurando estudar se em condições supercríticas existem diferenças de razões molares desses álcoois nas condições envolvidas na reação.

\section{Experimental}

As medidas experimentais para produção de biodiesel realizadas nesta etapa do trabalho foram conduzidas no aparato experimental desenvolvido e apresentado no capítulo 1. Após os testes de vazão, previamente detalhados, procedeu-se então à consecução dos experimentos de produção de biodiesel na unidade proposta.

\subsection{Matérias-primas}

O óleo de soja refinado (CARGILL, Mairinque, Brasil) foi adquirido de um mesmo lote de fabricação em uma quantidade suficiente para conduzir todos os experimentos de síntese do biodiesel. Nenhum tratamento prévio foi realizado com o óleo, porém foi efetuada uma caracterização para determinação dos triglicerídeos presentes e também para avaliação da pureza do mesmo. A caracterização foi realizada por meio de cromatografia gasosa. Foi utilizado um cromatógrafo gasoso (SHIMADZU, Kyoto, Japão) equipado com detector por ionização de chama (FID) a $380^{\circ} \mathrm{C}$, um sistema de injeção split trabalhando em uma temperatura de $360^{\circ} \mathrm{C}$, com razão de 1:20, e uma coluna capilar com fase $5 \%$ fenil, $95 \%$ metilpolisiloxano (NST5-HT 10mX0,25mmX0,08um) (NST, São Carlos, Brasil) com a programação de temperatura apresentada na Tabela 2.1. O óleo de soja foi diluído em n-hexano (MERCK, Darmstadt, Alemanha) na concentração de $100 \mathrm{mg} / \mathrm{mL}$.

A identificação dos triglicerídeos, e avaliação da pureza do óleo de soja, foi acompanhada pela injeção de padrões autênticos e pela determinação dos tempos de retenção de cada composto, sendo a quantificação dos triglicerídeos realizada por padronização interna. Os padrões utilizados nesta etapa do trabalho, glicerina $\geq 99,5 \%$, monoleína $\geq 99 \%$, dioleína $\geq 99 \%$, tripalmitina $99 \%$, tristearina $\geq$ $99 \%$, trioleína $\geq 99 \%$, trilinoleína $\geq 98,5 \%$, trilinolenina $\geq 97 \%$, tricaprina $\geq 99 \%$ foram todos adquiridos de um mesmo fabricante (SIGMA-ALDRICH, Saint Louis, EUA). Tricaprina foi utilizado como padrão interno. Os padrões foram adquiridos com base na composição média do óleo de soja comercial indicado na literatura ${ }^{32}$ como é mostrado na Tabela 2.2. 
Tabela 2.1 - Programação de temperatura do forno para caracterização e quantificação do óleo de soja

\section{Programação de Temperatura}

do forno da coluna

Temperatura Inicial

Rampa 1

Rampa 2

Rampa 3 $50^{\circ} \mathrm{C}$

$7^{\circ} \mathrm{C} / \mathrm{min}$ até $200^{\circ} \mathrm{C}$

$5^{\circ} \mathrm{C} / \mathrm{min}$ até $297^{\circ} \mathrm{C}$

$5^{\circ} \mathrm{C} / \mathrm{min}$ até $360^{\circ} \mathrm{C}$
Permanência de 3

minutos

Permanência de 5

minutos

Permanência de 2

minutos

Permanência de 15

minutos

Tabela 2.2 - Composição média do óleo de soja comercial.

\begin{tabular}{cc} 
Triglicerídeo & Óleo de soja (\% massa) \\
\hline Trioleína & 25,00 \\
Trilinoleína & 64,00 \\
Tripalmitina & 7,00 \\
Tristearina & 4,00 \\
\hline & adaptado de MADRAS 2004
\end{tabular}

Metanol secado 99,8\% e etanol anidro $\geq 99,5 \%$ (J.T.BACKER, Phillipsburg, USA) também foram utilizados na síntese do biodiesel, porém nenhum tratamento e nenhuma análise prévia foram realizados nesses reagentes.

\subsection{Procedimento experimental para produção de biodiesel em reator supercrítico}

Os experimentos foram realizados para obtenção de dados de conversão da reação de transesterificação do óleo de soja com fluidos pressurizados em um sistema em batelada. Os experimentos para a produção de biodiesel de óleo de soja foram executados seguindo um planejamento $2^{3}$. A partir dos resultados obtidos deste planejamento pode-se determinar se as reações são melhor conduzidas em 
meios sub ou supercríticos para etanol e metanol, além da avaliação da influência das variáveis. Posteriormente, foi avaliada a ação da adição de água na reação utilizando a melhor condição obtida.

\subsection{Planejamento de Experimentos}

Embora sendo reversível, o equilíbrio de uma reação de transesterificação tende a favorecer a formação do éster. A reação acontece essencialmente por mistura de reagentes, porém, o deslocamento pode ser influenciado por uma série de aspectos, os quais podem atuar isoladamente ou em conjunto ${ }^{5}$, destacando-se o tempo e a temperatura de reação, além da razão molar óleo/álcool. Para a escolha das variáveis e dos intervalos a serem investigadas no presente trabalho, algumas considerações em relação às mesmas são descritas no decorrer do texto.

Geralmente, a taxa de conversão da reação de transesterificação aumenta com o tempo de reação. FREEDMAN et a $\beta^{\beta 3}$ verificaram que o aumento do tempo de reação fez com que a taxa de conversão em biodiesel aumentasse consideravelmente, alcançando valores de até $98 \%$, sob relação molar metanol:óleo de $6: 1,0,5 \%$ do catalisador metóxido de sódio à $60^{\circ} \mathrm{C}$ e usando os óleos de soja e girassol como matéria-prima.

A temperatura é uma das variáveis que mais influencia a velocidade e o rendimento da reação de transesterificação. Normalmente a reação é conduzida a temperaturas relativamente baixas, em torno de 40 a $70^{\circ} \mathrm{C}$, tendo como limite superior a temperatura do ponto de ebulição do álcool utilizado à pressão atmosférica. Contudo, um aumento na temperatura de reação, especialmente a temperatura supercrítica do álcool, traz uma influencia favorável na conversão dos ésteres. $^{34}$

Outra importante variável que afeta o rendimento de ésteres é a razão molar. Estequiometricamente, a reação de transesterificação de óleos vegetais exige 3 mols do agente transesterificante para cada mol de triglicerídeo, de onde se formam 3 mols de éster e $1 \mathrm{~mol}$ de glicerina. Apesar de estarem associadas ao tipo de catalisador utilizado, em geral quanto maior o excesso de álcool maiores serão as taxas de conversão e menor é o tempo de reação. ${ }^{34}$ Reações de transesterificação metílica catalisadas por álcali requerem razões molares álcool:óleo que variam entre 3:1 a 6:1, enquanto que em reações catalisadas por ácidos, a razão molar pode chegar a valores como 30:1. ${ }^{33}$ 
Desta forma, para uma avaliação mais precisa das variáveis que influenciam na reação de transesterificação adotou-se um planejamento prévio $2^{3}$ para avaliar a necessidade de condições sub ou supercríticas para que um bom rendimento fosse alcançado nas reações de óleo de soja com metanol e etanol pressurizados. A resposta a medir, ou seja, a variável dependente, foi a porcentagem de biodiesel produzido (conversão). Os fatores escolhidos, ou as variáveis independentes utilizadas no processo de produção de biodiesel foram: temperatura, relação molar óleo/álcool e tempo. Os níveis utilizados para metanol e etanol estão descritos na Tabela 2.3.

Tabela 2.3 - Níveis para o planejamento fatorial $2^{3}$. Processo de produção de biodiesel a partir do óleo de soja e metanol ou etanol em reator supercrítico

Variável

Temperatura

Relação Molar

óleo/álcool

Tempo
Nível inferior (-1)

Nível superior $(+1)$

\begin{tabular}{ccc}
\hline Temperatura & $180^{\circ} \mathrm{C}$ & $300^{\circ} \mathrm{C}$ \\
Relação Molar & $1: 10(\mathrm{~mol} / \mathrm{mol})$ & $1: 50(\mathrm{~mol} / \mathrm{mol})$ \\
óleo/álcool & 10 minutos & 1 hora \\
Tempo & 10 \\
\hline
\end{tabular}

No processo de produção de biodiesel, para o presente trabalho a temperatura investigada de $180^{\circ} \mathrm{C}$ foi utilizada por estar abaixo das temperaturas críticas do metanol $\left(239,45^{\circ} \mathrm{C}\right)$ e do etanol $\left(240,75^{\circ} \mathrm{C}\right)^{35}$ e a temperatura de $300^{\circ} \mathrm{C}$ por ser superior às temperaturas críticas do metanol e etanol. Variou-se o tempo de de 10 minutos à 1 hora, baseado em dados da literatura que apresentam reações de curto e altos tempos reacionais com rendimentos distintos. ${ }^{33,34,36,37,38} \mathrm{~A}$ utilização de relação molar de 1:10 se deve ao fato de estar menos distante da razão molar estequiométrica da reação de transesterificação, a qual requer 3 mols de álcool, para um mol de triglicerídeo, e a relação molar 1:50 por representar um excesso de álcool. As pressões do sistema foram anotadas quando a temperatura requerida era atingida. No caso de reatores em batelada a pressão depende basicamente da temperatura, mas o volume do reator ocupado pela mistura líquida, após o carregamento, tem influência na pressão a ser atingida na temperatura desejada. ${ }^{39}$ No presente trabalho optou-se por carregar o reator visando obter densidade global 
(razão entre a massa do líquido e o volume do reator) em torno de 0,6 $\mathrm{gcm}^{3}$. Para avaliar experimentalmente a evolução da conversão do óleo de soja em metanol e etanol pressurizados foram realizados experimentos em duplicata. A massa do óleo utilizada em cada condição experimental foi fixada. Por meio da Tabela 2.4 pode-se visualizar a matriz do planejamento experimental realizado.

Tabela 2.4 - Matriz de planejamento $2^{3}$ para as reações de biodiesel a partir do óleo de soja e metanol ou etanol em reator para fluidos pressurizados

\begin{tabular}{cccc} 
Experimentos & Temperatura & Relação molar & Tempo \\
\hline 1 & -1 & -1 & -1 \\
2 & +1 & -1 & -1 \\
3 & -1 & +1 & -1 \\
4 & +1 & +1 & -1 \\
5 & -1 & -1 & +1 \\
6 & +1 & -1 & +1 \\
7 & -1 & +1 & +1 \\
8 & +1 & +1 & +1 \\
\hline
\end{tabular}

Tais experimentos foram executados em sequência aleatória, sendo que os efeitos da variação da temperatura, da relação molar, do tempo e de suas interações sobre o rendimento em produção do biodiesel foram calculados utilizando-se o método planejamento fatorial do programa "Statistica 7.0".

É importante notar que quando se opera com o processo em batelada, o controle da temperatura e da pressão da reação, de forma independente, é bastante difícil, uma vez que a pressão do sistema é resultado da temperatura da reação. À medida que se usa maior volume inicial de líquido no reator, o espaço disponível para ser ocupado pela fase gasosa diminui e com a elevação da temperatura maiores valores de pressão podem ser alcançadas, por isso as pressões foram medidas. 


\subsection{Síntese do biodiesel de óleo de soja em metanol e etanol pressurizados}

Mediante estabilização da temperatura do forno, iniciava-se a contagem do tempo de batelada. O procedimento operacional em etapas é apresentado a seguir:

a) Carregamento do reator com quantidades previamente medidas de óleo de soja e metanol ou etanol;

b) fechamento do reator;

c) conecção com o manômetro;

d) aquecimento do reator até a temperatura desejada por meio do controlador de temperatura do forno. Foi estabelecido um tempo e estabilização do sistema de 1 minuto para todas as reações;

e) operação do sistema durante o tempo estabelecido para cada reação;

f) parada da batelada mudando o valor da temperatura para $30^{\circ} \mathrm{C}$. A redução gradativa da pressão era obtida por meio do resfriamento da cela reacional;

g) remoção do isolamento e resfriamento no banho de gelo durante 5 minutos;

h) abertura do reator e descarregamento da cela.

A reação ocorria de maneira a atingir a temperatura do experimento, determinado no planejamento. A pressão crítica do álcool foi atingida apenas com o aumento da temperatura. Como a cela de reação foi colocada dentro do forno, as temperaturas reportadas foram as temperaturas do forno. No caso das reações com adição de água seguiu-se o mesmo procedimento, porém com a água sendo adicionada juntamente com o óleo e o álcool durante a etapa de carregamento do reator.

\subsection{Preparo da amostra para quantificação dos ésteres - processo de separação dos produtos da reação}

O processo de purificação dos ésteres compreende na separação das fases entre os ésteres, mono, di e triglicerídeos (fase superior apolar) e o glicerol e álcool não reagido (fase inferior polar). O procedimento ocorreu como descrito a seguir:

Após a coleta das amostras, eram pesadas cerca de $100 \mathrm{mg}$ da amostra as quais eram transferidas para um tubo de ensaio no qual eram adicionados $400 \mu \mathrm{L}$ de solução saturada de NaCL p.a. $\geq 99,5 \%$ (SIGMA-ALDRICH, Saint Louis, EUA) e 4 $\mathrm{mL}$ de $\mathrm{n}$-hexano. A extração realizada ocorreu com auxílio de homogeneizador tipo 
vortex por 1 minuto. Após ocorrer a separação da fase inferior (álcool não reagido e glicerol) e fase superior (ésteres, mono, di e triglicerídeos), transferia-se a fase superior do tubo de ensaio (fase hexânica) para um balão volumétrico de $10 \mathrm{~mL}$ e completava-se com n-hexano. Logo após, transferia-se uma alíquota de $100 \mu \mathrm{L}$ desta solução para um balão volumétrico de $1 \mathrm{~mL}$ e adicionava-se $50 \mu \mathrm{L}$ de solução do padrão interno heptadecanoato de metila $\geq 99 \%$ ou etila (SIGMA-ALDRICH, Saint Louis, EUA) na concentração de $5000 \mathrm{mg} / \mathrm{L}$, completando-se o volume com nhexano. Procedeu-se então a análise cromatográfica. Este procedimento garante que todos os ésteres produzidos, assim como mono, di e triglicerídeos além de ácidos graxos não reagidos, estivessem na solução a ser introduzida no cromatógrafo.

\subsection{Determinação da conversão da reação em ésteres}

O rendimento da reação depende do deslocamento do equilíbrio em favor dos ésteres produzidos. Portanto, neste trabalho, a conversão da reação foi considerada como sendo a conversão em termos de ésteres metílicos e etílicos. Neste contexto, os resultados apresentados dizem respeito ao biodiesel puro (B100) produzido em relação à quantidade de óleo. A identificação química dos picos cromatográficos baseou-se na comparação om os padrões de ésteres metílicos e etílicos.

Os padrões cromatográficos de ésteres etílicos e metílicos (palmitato de etila/metila, oleato de metila/etila, linoleato de metila/etila, linolenato de metila/etila e heptadecanoato de metila/etila) que foram utilizados na caracterização do biodiesel foram adquiridos de um mesmo fabricante (SIGMA-ALDRICH, Saint Louis, EUA).

A quantificação em ésteres foi realizada baseada na norma EN 14103. As análise foram efetuadas em um cromatógrafo gasoso GC-2010 (SHIMADZU, Kyoto, Japão) equipado com detector por ionização de chama e um sistema de injeção trabalhando ambos a $230 \stackrel{\circ}{\circ}$. As amostras eram injetadas a uma razão de split 1:20. A coluna cromatográfica foi uma coluna capilar com fase $100 \%$ polietilenoglicol

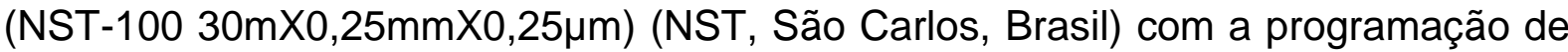
temperatura apresentada na Tabela 2.5. Foram preparadas 3 replicatas.

Através dos picos cromatográficos e suas respectivas áreas, foi calculada a conversão de ésteres pela Equação 1. 
Tabela 2.5 - Programação de temperatura do forno para caracterização e quantificação dos biodieseis etílicos e metílicos do óleo de soja

\section{Programação de Temperatura do}

forno da coluna

Temperatura

Inicial

Rampa 1

Rampa 2 $170^{\circ} \mathrm{C}$

$10^{\circ} \mathrm{C} / \mathrm{min}$ até $210^{\circ} \mathrm{C}$

minuto

Permanência de 2

minutos

Conversão de ésteres $(\%)=\left(\frac{\sum \text { Aamostra }}{\text { Apadrão interno }}\right) *\left(\frac{\text { Cpadrão interno }}{\text { Camostra }}\right) * 100$

onde: $\sum A$ amostra é a somatória das áreas correspondentes a picos do biodiesel (região dos ésteres); Apadrão interno é a área do padrão interno (C17:0 heptadecanoato de metila ou etila); Cpi é a concentração do padrão interno na amostra injetada (aproximadamente $250 \mathrm{mg} / \mathrm{L}$ ) e Camostra é a concentração da amostra injetada (aproximadamente $1000 \mathrm{mg} / \mathrm{L}$ ).

\subsection{Verificação da influência da adição de água na reação}

Os parâmetros encontrados na melhor condição do planejamento fatorial foram mantidos fixos e variou-se apenas a concentração da água na proporção de 0 ; 2,5; 5; 7,5 e 10\% em relação a massa de óleo adicionada ao reator. Estes valores foram escolhidos por estarem abaixo de 500ppm do volume total adicionado à cela reacional, evitando complicações maiores relacionadas ao limite estabelecido pelas normas.

Como o biodiesel é higroscópico, a água pode hidrolisar ésteres, formando ácidos livres que, por sua vez, formam sabões provocando corrosão de 
materiais e degradação do combustível, além de estabelecer um meio fértil para crescimento de micro-organismos. Portanto, é importante que a água existente no meio, após a purificação do biodiesel, não ultrapasse o limite estabelecido pelas normas utilizadas para caracterização de biodiesel que é de $0,05 \%$ em volume (500ppm). ${ }^{1}$

\section{Resultados e Discussão}

\subsection{Monitoramento do óleo de soja}

A composição aproximada do óleo de soja determinada por análise cromatográfica estava em concordância com os dados da literatura apresentados na Tabela 2.2; a massa molecular $(876,33)$ do óleo de soja foi calculada pela ponderação das massas molares dos constituintes do óleo.

\subsection{Reação de transesterificação}

Para melhor entendimento das reações de transesterificação que ocorrem em meio supercrítico, será previamente explicado o mecanismo de transesterificação em meios alcalinos e ácidos. Na Figura 2.4 é mostrado o mecanismo de reação da transesterificação de triglicerídeos com metanol em meio alcalino. ${ }^{40} \mathrm{~A}$ reação com etanol ocorre de maneira similar. $\mathrm{Na}$ transesterificação dos óleos vegetais catalisado por base a espécie ativa é um alcóxido. Na etapa 1, o metanol em equilíbrio ácido-base com o catalisador é desprotonado formando o ânion alcóxido. $\mathrm{Na}$ etapa seguinte, um átomo de carbono carbonílico de um dos grupos acila do triglicerídeo sofre um ataque nucleofílico do metóxido, formando um intermediário tetraédrico. Na etapa 3, a partir de um rearranjo do intermediário forma-se o éster metílico e o ânion (base conjugada do glicerol) o qual, na etapa 4, após a desprotonação do ácido conjugado da base formada na etapa 1, regenera a base de partida e produz, neste caso, um diglicerídeo. Reações similares irão ocorrer com os diglicerídeos formados, produzindo mais uma molécula de éster e monoglicerídeo, o qual, em processos similares, formará facilmente a glicerina. ${ }^{40}$

Vale ressaltar que a reação dos hidróxidos de sódio e de potássio com o álcool leva à formação de água e, na presença do catalisador básico, poderá levar à hidrólise de algum éster produzido, com consequente formação de sabão, como mostra a Figura 2.5. Esta saponificação indesejável reduz o rendimento do éster e dificulta consideravelmente a recuperação do glicerol, devido à formação de 
emulsão. Portanto, para uma transesterificação catalisada por bases, ambos os óleos ou gorduras e álcool devem ser isentos de água. ${ }^{41}$

Figura 2.4 -Mecanismo de reação de transesterificação alcalina de triglicerídeos com metanol, onde B é uma base e R é uma cadeia hidrocarbônica.

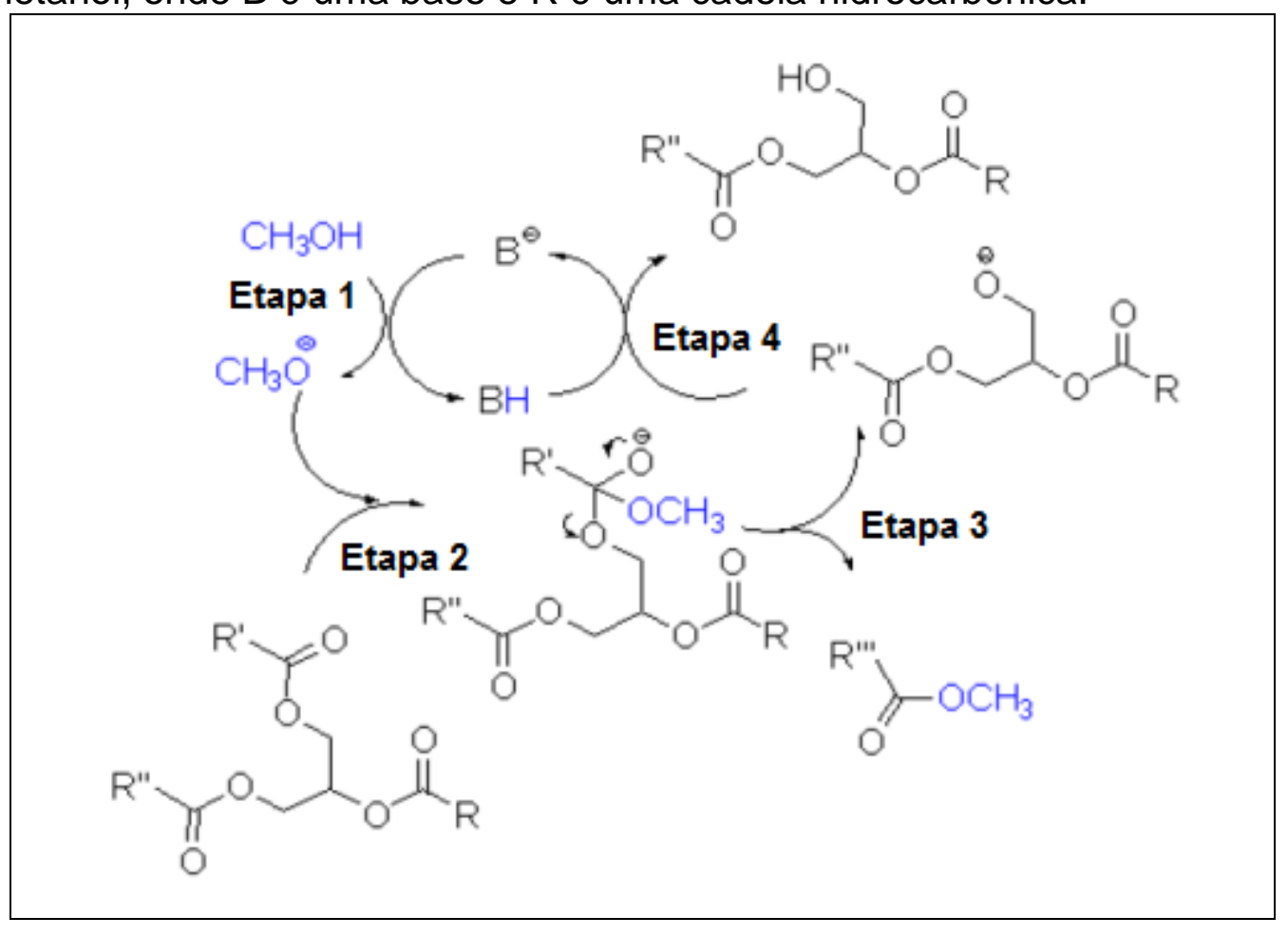

adaptado de SCHUCHARDT. ${ }^{40}$

Figura 2.5 - Reação secundária durante a transesterificação utilizando hidróxido de potássio.

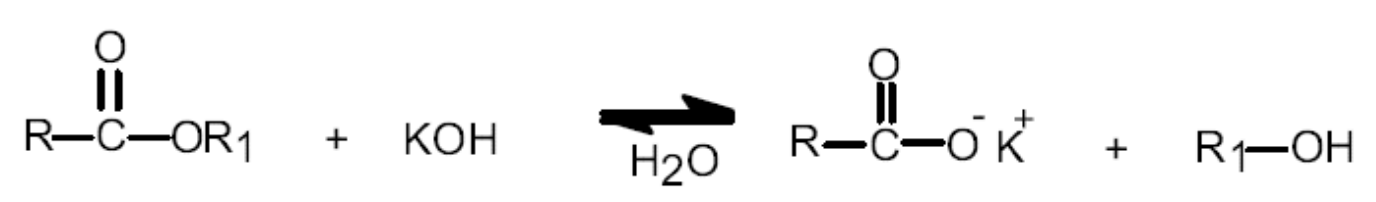

Na Figura 2.6 é mostrado o mecanismo de reação de transesterificação de triglicerídeos com metanol em meio ácido. O mecanismo para as reações utilizando etanol é similar ao apresentado para as reações metílicas. Na catálise ácida a baixa reatividade do nucleófilo, isto é, o álcool, é compensada na primeira etapa através da ativação da carbonila por um ataque eletrofílico do $\mathrm{H}^{+}$vindo do catalisador. Ocorre, portanto, nesta etapa, a formação de um carbocátion. A seguir, na segunda etapa, este carbocátion sofre um ataque nucleofílico de uma molécula de álcool, formando um intermediário tetraédrico. No intermediário tetraédrico, uma 
transferência de hidrogênio prepara o grupo de saída. Então, na etapa 4, o éster graxo é formado pela a eliminação de, neste caso, um diglicerídeo completando a substituição acílica. A etapa 5 corresponde ao equilíbrio ácido-base que restaura o catalisador. Por processos semelhante serão formados os monoglicerídeos e a glicerina. ${ }^{40}$

Figura 2.6 - Mecanismo de reação de transesterificação ácida de triglicerídeos com metanol.

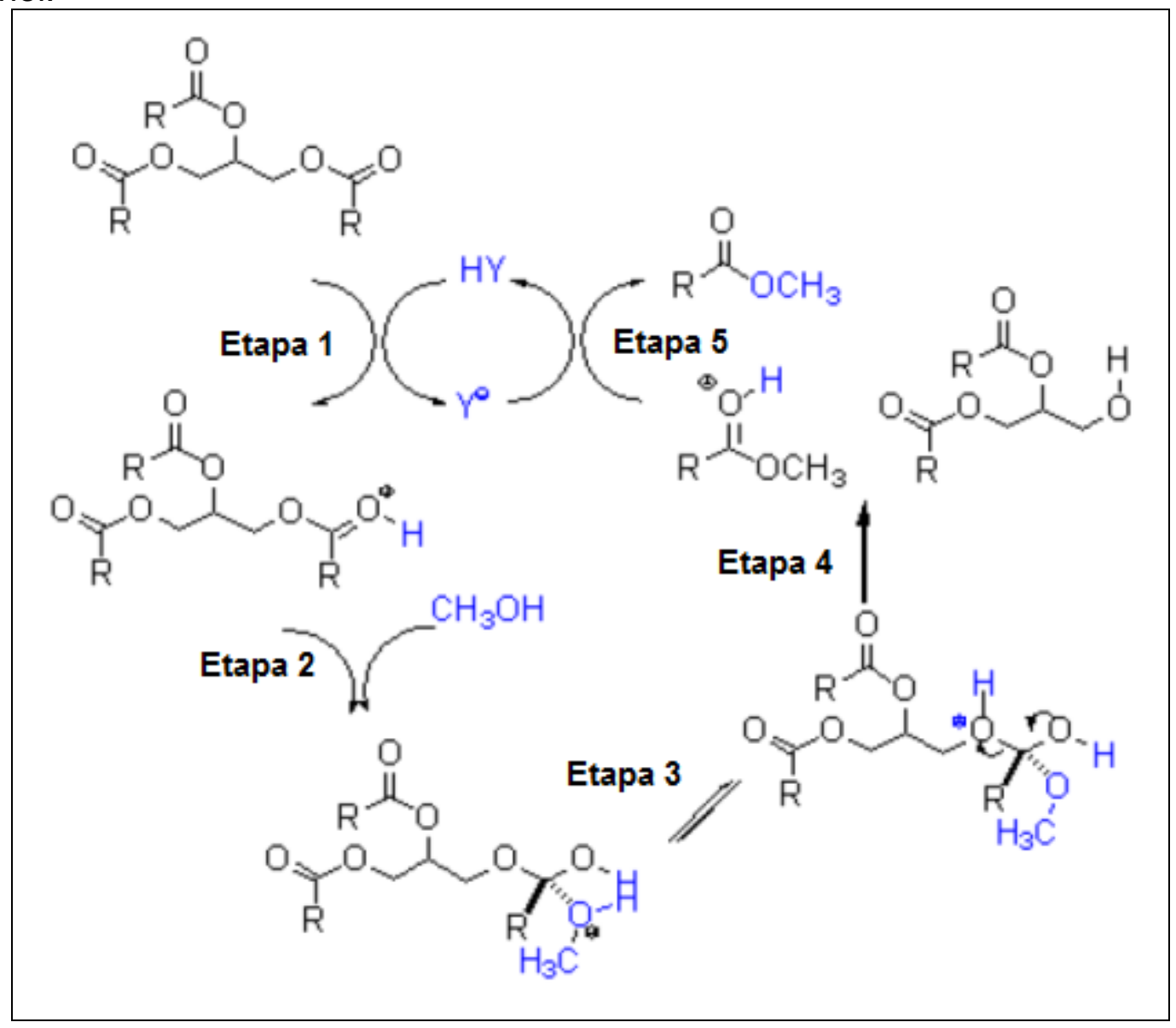

adaptado de SCHUCHARDT ${ }^{40}$

O mecanismo da reação de transesterificação do óleo vegetal com metanol supercrítico, apresentado na Figura 2.7, foi proposto por KUSDIANA e SAKA ${ }^{42}$ baseado no mecanismo desenvolvido por KRAMMER e por VOGEL ${ }^{43}$ para a hidrólise de ésteres em água no estado sub/supercrítico. O mecanismo proposto considera que metanol e etanol sob condições supercríticas apresentam comportamento similar ao de um catalisador ácido. Na reação de transesterificação em álcool supercrítico não-catalítico, supõe-se que uma molécula do álcool ataca diretamente a carbonila do triglicerídeo devido à elevada pressão, formando um 
complexo tetraédrico. No estado supercrítico, dependendo da pressão e da temperatura, a ligação do hidrogênio é significativamente mais fraca, permitindo que o metanol se torne um monômero livre. A ligação do hidrogênio é enfraquecida de 1,9 em condições normais a 0,7 no estado supercrítico. A reação de transesterificação é completada através da transferência do metóxido, formando éster metílico e diglicerídeo. De maneira similar, o diglicerídeo é transesterificado formando éster metílico e monoglicerídeo que é convertido em mais uma molécula de éster metílico e glicerina na última etapa. ${ }^{42}$

Figura 2.7 - Proposta de mecanismo de reação de transesterificação de triglicerídeos em metanol supercrítico.

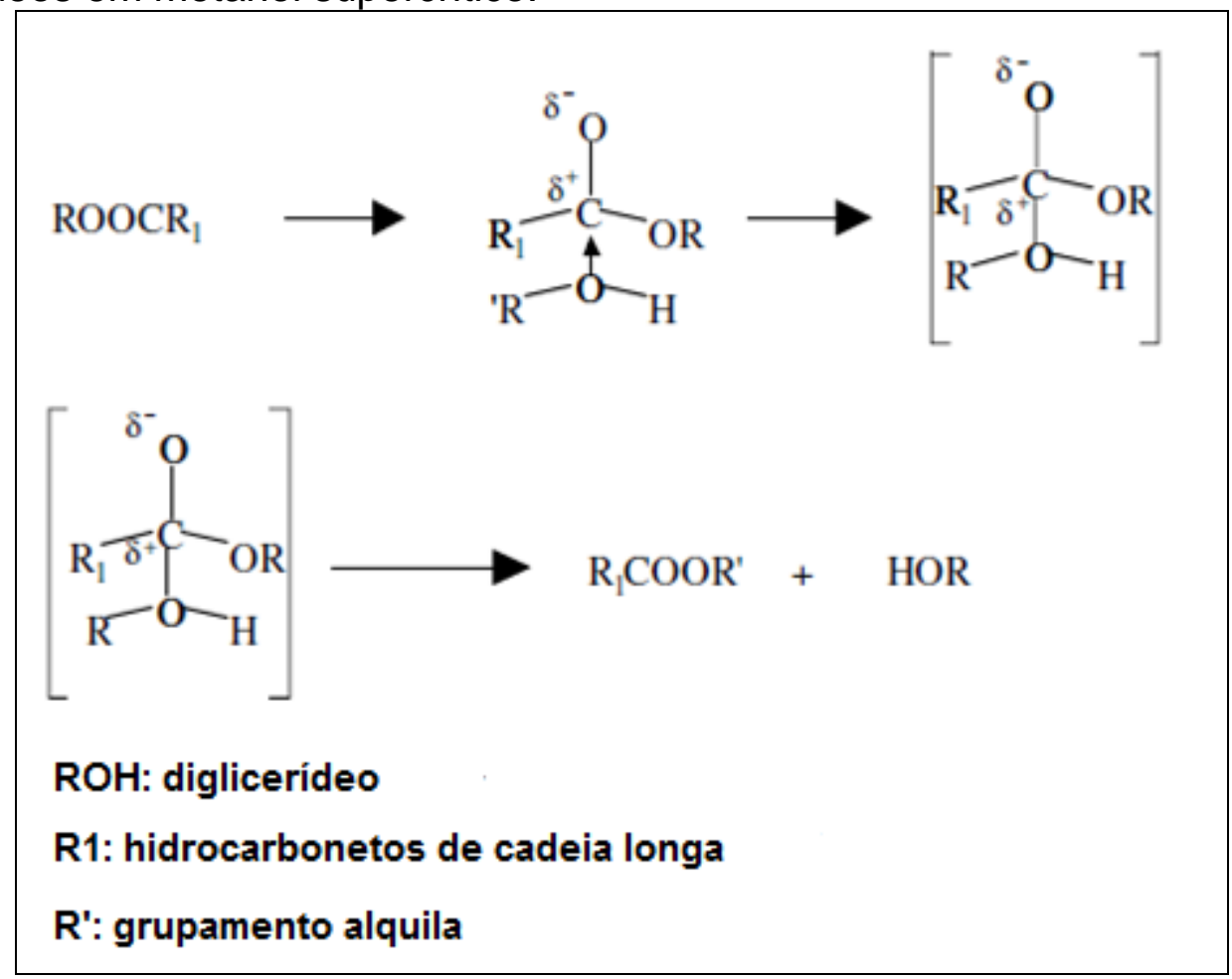

Adaptado de KUSDIANA, D.; SAKA, S. ${ }^{42}$

Metanol e etanol líquidos são altamente polares e têm pontes de hidrogênio ligando o oxigênio de uma hidroxila ao hidrogênio de outra hidroxila que formam aglomerados de moléculas. No estado supercrítico, dependendo da pressão e temperatura, o número de pontes de hidrogênio decresce significativamente o que permite que as moléculas dos álcoois ajam livremente e assumam natureza hidrofóbica com baixa constante dielétrica. Consequentemente, os triglicerídeos, que são fracamente polares, podem ser facilmente solvatados com os álcoois formando uma mistura homogênea o que facilita a reação. No entanto há ainda uma falta de 
consenso sobre os mecanismos das reações envolvidas na síntese de biodiesel em meio supercrítico.

\subsection{Monitoramento da reação de transesterificação - determinação dos percentuais de conversão}

$\mathrm{Na}$ Tabela 2.6 são apresentadas as propriedades termo-físicas dos reagentes utilizados neste trabalho.

Tabela 2.6 - Propriedades termo-físicas dos reagentes utilizados para a síntese do biodiesel com álcool supercrítico em batelada sem a presença de catalisador.

\begin{tabular}{ccccc} 
Substância & $\begin{array}{c}\text { Massa } \\
\text { Molecular } \\
\left(\mathbf{g} \cdot \mathbf{m o l}^{-1}\right)\end{array}$ & $\begin{array}{c}\text { Temperatura } \\
\text { crítica }\left({ }^{\circ} \mathbf{C}\right)\end{array}$ & $\begin{array}{c}\text { Pressão } \\
\text { crítica (atm) }\end{array}$ & $\begin{array}{c}\text { Densidade a } \\
\mathbf{2 0}{ }^{\circ} \mathbf{C}\left(\mathbf{g} \cdot \mathbf{c m}^{-3}\right)\end{array}$ \\
\hline $\begin{array}{c}\text { Metanol } \\
\left(\mathrm{CH}_{3} \mathrm{OH}\right)\end{array}$ & 32,04 & 239,45 & 78,9 & $0,791-0,793$ \\
$\begin{array}{c}\text { Etanol } \\
\left(\mathrm{C}_{2} \mathrm{H}_{5} \mathrm{OH}\right)\end{array}$ & 46,07 & 240,75 & 60,6 & $0,790-0,793$ \\
Óleo de soja & 876,33 & 969,82 & 3,31 & 0,8825 \\
\hline
\end{tabular}

Adaptado de DEMIRBAS, A. $^{37}$ e SANTOS ${ }^{44}$

O óleo de soja tem a sua composição em triglicerídeos centrada em ácidos graxos insaturados. O biodiesel metílico do óleo de soja que representa mais de $70 \%$ da produção brasileira de grãos é, de fato, composto majoritariamente por ésteres de ácidos graxos insaturados, tais como oleato de metila e linoleato de metila. ${ }^{45,46}$

No trabalho realizado, as análises dos ésteres nas condições de reação estudadas, tanto para o metanol quanto para o etanol, revelaram que ésteres com maiores números de instaurações apresentam uma diminuição de $20 \%$ em relação ao esperado. A extrema pressão atingida nas reações de transesterificação em metanol e etanol supercríticos provavelmente afetam a cadeia carbônica dos triglicerídeos, fazendo com que as ligações duplas, por serem mais frágeis, sejam quebradas durante a reação. Também pode ter ocorrido decomposição térmica e hidrogenação dos ésteres insaturados já formados devido às elevadas temperaturas 
aplicadas. A partir desses resultados foi possível perceber que a produção de biodiesel com metanol e etanol supercríticos, sob o aspecto de redução das instaurações, permite vislumbrar a possibilidade de reduzir os índices de iodo do biodiesel, pois sabe-se que os ácidos graxos insaturados são susceptíveis a reações de oxidação aceleradas pela exposição ao oxigênio e altas temperaturas, condições que são pertinentes ao funcionamento do motor. ${ }^{47} \mathrm{~A}$ redução do índice de iodo do biodiesel brasileiro torna-o mais competitivo tendo em vista a exportação, pois as especulações técnicas da União Europeia para o biodiesel vêm dificultando a entrada do produto brasileiro nos países do bloco, e podem representar mais um revés para a indústria nacional. Porém, não é recomendada a excessiva redução do índice de iodo, visto que amostras de biodiesel que possuem um grau de instauração muito baixo são instáveis quando submetidas a baixas temperaturas, podendo precipitar. Entretanto, esse não se aplica ao biodiesel de óleo de soja produzido em condições de metanol e etanol supercríticos neste trabalho, pois ocorreu uma transformação de apenas $20 \%$ dos ésteres insaturados esperados.

As conversões obtidas para o planejamento experimental do metanol e etanol estão apresentados nas Tabelas 2.7 e 2.8, respectivamente. Pode ser observado que não ocorreu inconstância de resultados, sendo possível uma conversão máxima de aproximadamente $95 \%$ nas reações com temperaturas supercríticas tanto para o metanol quanto para o etanol, para os níveis analisados. As conversões relatadas na literatura em condições ao redor das estudadas neste trabalho para óleo de dendê e etanol em regime de batelada foi de aproximadamente $80 \%{ }^{3}$

\subsection{Efeito das variáveis e suas interações}

\subsubsection{Reações de óleo de soja com metanol pressurizado}

A análise dos efeitos estimados das variáveis em relação a conversão da reação (Tabela 2.9) demonstra que o tempo (3), a temperatura (1), a razão molar óleo/álcool (2) e a interação entre a temperatura e o tempo de residência (1 by 3) são significativas. Já as interações entre temperatura e razão molar ( 1 by 2 ), e também tempo e razão molar ( 2 by 3 ) não se apresentaram como significativas. Pode-se concomitantemente observar, por meio dos efeitos estimados, que com o aumento da temperatura e do tempo aumenta-se também a conversão em ésteres 
Tabela 2.7 - Conversões obtidas no planejamento $2^{3}$ das reações de transesterificação do óleo de soja em metanol pressurizado utilizando os níveis apresentada na Tabela 2.3.

\begin{tabular}{cccccc} 
Experimentos & Temperatura & $\begin{array}{c}\text { Relação } \\
\text { molar }\end{array}$ & Tempo & $\begin{array}{c}\text { Conversão } \\
\mathbf{1}\end{array}$ & $\begin{array}{c}\text { Conversão } \\
\mathbf{2}\end{array}$ \\
\hline 1 & -1 & -1 & -1 & $20 \%$ & $23 \%$ \\
2 & +1 & -1 & -1 & $70 \%$ & $72 \%$ \\
3 & -1 & +1 & -1 & $15 \%$ & $20 \%$ \\
4 & +1 & +1 & -1 & $60 \%$ & $63 \%$ \\
5 & -1 & -1 & +1 & $30 \%$ & $32 \%$ \\
6 & +1 & -1 & +1 & $95 \%$ & $94 \%$ \\
7 & -1 & +1 & +1 & $15 \%$ & $15 \%$ \\
8 & +1 & +1 & +1 & $90 \%$ & $89 \%$ \\
\hline
\end{tabular}

Tabela 2.8 - Conversões obtidas no planejamento $2^{3}$ das reações de transesterificação do óleo de soja em etanol pressurizado utilizando os níveis apresentada na Tabela 2.3.

\begin{tabular}{cccccc} 
Experimentos & Temperatura & $\begin{array}{c}\text { Relação } \\
\text { molar }\end{array}$ & Tempo & $\begin{array}{c}\text { Conversão } \\
\mathbf{1}\end{array}$ & $\begin{array}{c}\text { Conversão } \\
\mathbf{2}\end{array}$ \\
\hline 1 & -1 & -1 & -1 & $20 \%$ & $20 \%$ \\
2 & +1 & -1 & -1 & $70 \%$ & $67 \%$ \\
3 & -1 & +1 & -1 & $17 \%$ & $18 \%$ \\
4 & +1 & +1 & -1 & $50 \%$ & $53 \%$ \\
5 & -1 & -1 & +1 & $27 \%$ & $25 \%$ \\
6 & +1 & -1 & +1 & $92 \%$ & $95 \%$ \\
7 & -1 & +1 & +1 & $15 \%$ & $15 \%$ \\
8 & +1 & +1 & +1 & $84 \%$ & $86 \%$ \\
\hline
\end{tabular}

metílicos. Também, foi verificado, para os níveis estudados, que um aumento na conversão dos ésteres é alcançado diminuindo-se a relação molar óleo/álcool. A temperatura foi a variável estudada mais significativa do processo com um efeito de aproximadamente $58 \%$, seguida do tempo de residência aproximadamente $15 \%$, seguindo a interação entre a temperatura e tempo de residências $11 \%$ e, por último, a razão molar com um efeito de aproximadamente $9 \%$ sobre a conversão na reação. 
Tabela 2.9 - Estimativa dos efeitos das variáveis e suas interações sobre o rendimento da reação de produção de biodiesel de óleo de soja obtidos do planejamento $2^{3} \mathrm{com}$ metanol pressurizado e seus respectivos limites de confiança.

\begin{tabular}{|l|r|c|c|c|r|r|r|r|r|r|}
\hline Factor & Effect & $\begin{array}{l}\text { Std.Err. } \\
\text { Pure Err }\end{array}$ & $\mathrm{t}(\mathbf{8})$ & $\mathrm{p}$ & $\begin{array}{r}-95, \% \\
\text { Cnf.Limt }\end{array}$ & $\begin{array}{c}+95, \% \\
\text { Cnf.Limt }\end{array}$ & Coeff. & $\begin{array}{c}\text { Std. Err. } \\
\text { Coeff. }\end{array}$ & $\begin{array}{c}-95, \% \\
\text { Cnf.Limt }\end{array}$ & $\begin{array}{c}+95, \% \\
\text { Cnf.Limt }\end{array}$ \\
\hline Mean/Interc. & 50,18750 & 0,455007 & 110,3005 & 0,000000 & 49,1383 & 51,23675 & 50,18750 & 0,455007 & 49,13825 & 51,23675 \\
\hline (1)Temperatura & 57,87500 & 0,910014 & 63,5979 & 0,000000 & 55,7765 & 59,97350 & 28,93750 & 0,455007 & 27,88825 & 29,98675 \\
\hline (2)Razão Molar & $-8,62500$ & 0,910014 & $-9,4779$ & 0,000013 & $-10,7235$ & $-6,52650$ & $-4,31250$ & 0,455007 & $-5,36175$ & $-3,26325$ \\
\hline (3)Tempo & 14,62500 & 0,910014 & 16,0712 & 0,000000 & 12,5265 & 16,72350 & 7,31250 & 0,455007 & 6,26325 & 8,36175 \\
\hline 1 by 2 & 1,37500 & 0,910014 & 1,5110 & 0,169243 & $-0,7235$ & 3,47350 & 0,68750 & 0,455007 & $-0,36175$ & 1,73675 \\
\hline 1 by 3 & 11,12500 & 0,910014 & 12,2251 & 0,000002 & 9,0265 & 13,22350 & 5,56250 & 0,455007 & 4,51325 & 6,61175 \\
\hline 2 by 3 & $-1,87500$ & 0,910014 & $-2,0604$ & 0,073313 & $-3,9735$ & 0,22350 & $-0,93750$ & 0,455007 & $-1,98675$ & 0,11175 \\
\hline
\end{tabular}

O diagrama de Pareto apresentado na Figura 2.8 mostra a análise dos efeitos estimados relativos entre as variáveis e suas interações sobre o rendimento das reações de transesterificação de óleo de soja em metanol pressurizado. Observa-se, novamente, que a temperatura foi a variável que mais influenciou a produção de biodiesel, promovendo um efeito relativo de $63 \%$ em relação às outras variáveis na produção de ésteres metílicos.

Figura 2.8 - Diagrama de pareto obtido do planejamento $2^{3}$ para as reações de produção de biodiesel de óleo de soja com metanol pressurizado.

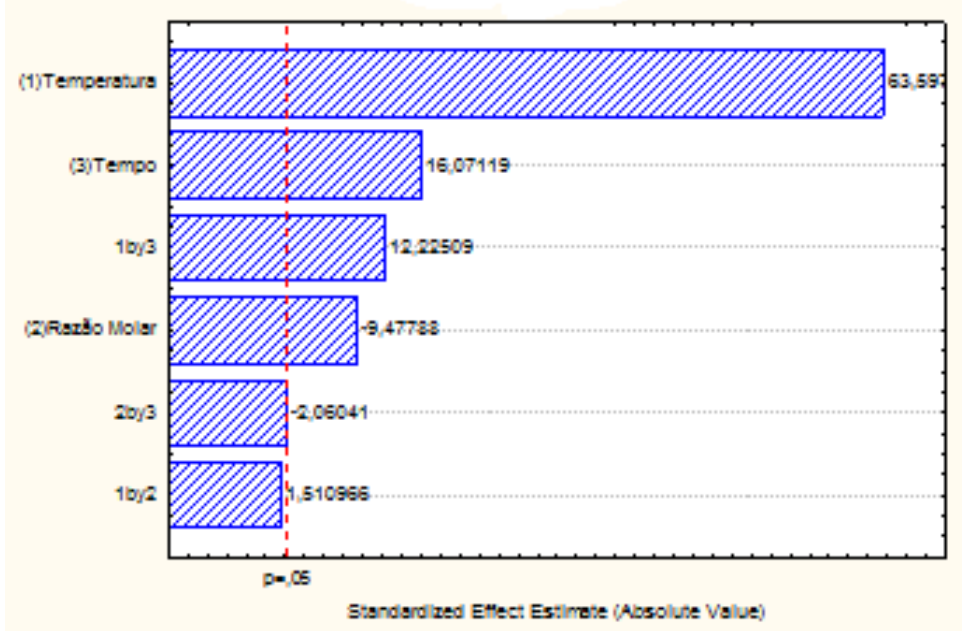

Também pode ser notada pouca dispersão entre os valores preditos e os valores observados na convers reação, como indicado no gráfico representado na Figura 2.9. Isto nos leva a conclusão de que o modelo responde bem aos dados obtidos, pois os valores obtidos e preditos são próximos. Por fim, um cubo (Figura 2.10) no qual nas arestas estão representados os valores preditos dos rendimentos em cada nível de cada fator, demonstra que, para um rendimento de $97 \%$ ser alcançado, deve-se estar a temperaturas de $300^{\circ} \mathrm{C}(+1)$, razão molar de 1:10 (-1) e 
tempo de 1 hora de reação $(+1)$. A pressão alcançada nessas condições para o metanol foi 250 atm cuja pressão crítica é 78.9 atm. Ou seja, as melhores condições de reação estão no estado supercrítico do metanol.

Figura 2.9 - Gráfico dos valores observados e dos valores obtidos do planejamento $2^{3}$ para 0 rendimento das reações de produção de biodiesel com metanol pressurizado.

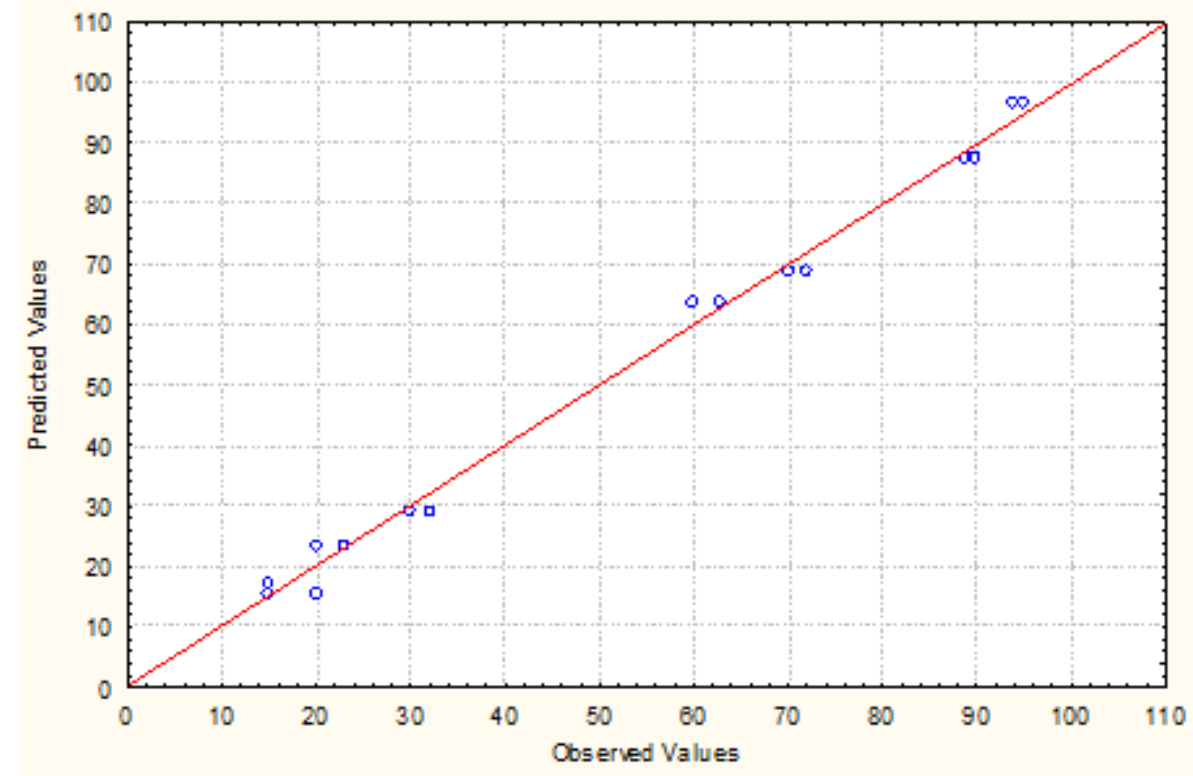

Figura 2.10 - Cubo que demonstra o planejamento $2^{3}$ para a conversão das reações de produção de biodiesel com metanol pressurizado.

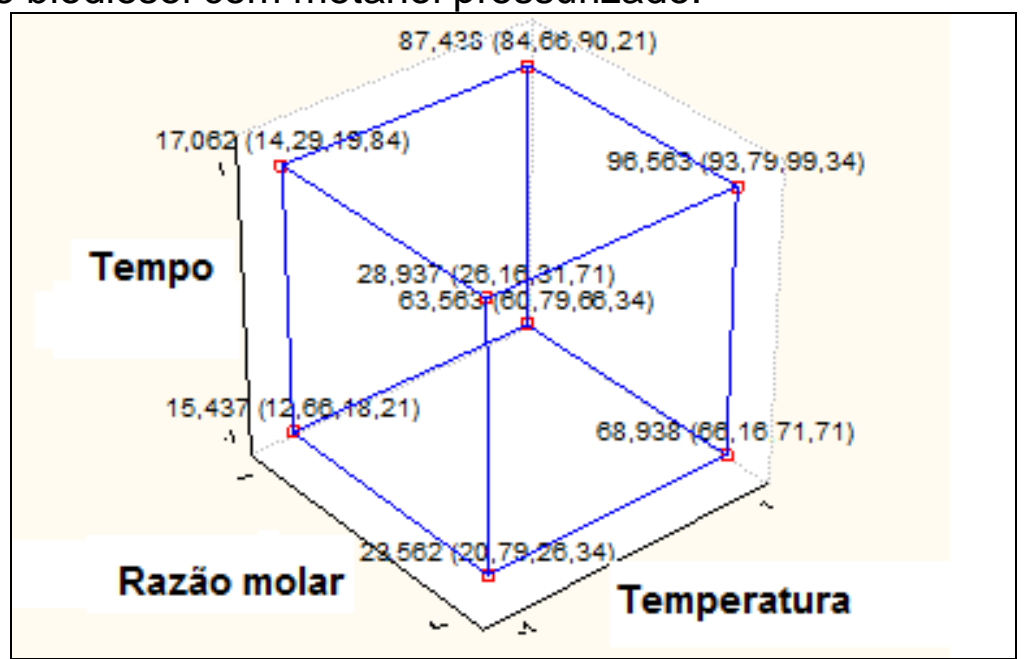


Pode-se concluir por meio dos resultados obtidos que temperaturas supercríticas são necessárias para uma boa conversão para reações de trasesterificação do óleo de soja com metanol pressurizado.

\subsubsection{Reações de óleo de soja com etanol pressurizado}

A análise dos efeitos estimados das variáveis em relação a conversão da reação (Tabela 2.10) demonstra a mesma tendência quando são comparadas às reações com metanol pressurizado. O tempo, a temperatura, a razão molar óleo/álcool e as interações entre a temperatura e o tempo de residência são significativas, assim como a interação de temperatura e razão molar juntamente com o tempo de residência e razão molar, não foram significativas. Pode-se também observar, como nas reações metílicas, que com o aumento da temperatura e do tempo de reação - além da diminuição da razão molar - aumenta-se a conversão da reação em ésteres etílicos. Neste caso, a temperatura também foi a variável mais significativa do processo com um efeito de aproximadamente $55 \%$, seguida do tempo de residência aproximadamente 16\%; logo após aparece a interação entre a temperatura e tempo de residência (14\%) e, por último, a razão molar com um efeito de aproximadamente $10 \%$ sobre o rendimento da reação. A influência das variáveis pode também ser confirmada por meio do diagrama de pareto apresentado na Figura 2.11. Confirmou-se, nesta figura, que a temperatura foi a variável que mais influenciou a produção de biodiesel, promovendo um efeito relativo de $34 \%$ em relação às outras variáveis na conversão da reação. Além disso, a pequena diferença dos valores preditos e dos valores observados (Figura 2.12) demonstra que modelo respondeu bem aos dados observados. Por fim, o cubo apresentado na Figura 2.13 demonstra que os valores preditos para cada nível de cada fator estão em concordância com os valores obtidos para as reações metílicas, pois para uma conversão de $96 \%$ ser alcançado deve-se estar a temperaturas de $300^{\circ} \mathrm{C}$, razão molar de 1:10 e tempo de 1 hora de reação. 
Tabela 2.10 - Estimativa dos efeitos das variáveis e suas interações sobre a conversão da reação de produção de biodiesel de óleo de soja obtidos do planejamento $2^{3}$ com etanol pressurizado e seus respectivos limites de confiança.

\begin{tabular}{|c|c|c|c|c|c|c|c|c|c|c|}
\hline Factor & Effect & Std.Err. & $t(9)$ & p & $\begin{array}{c}-95, \% \\
\text { Cnf.Limt }\end{array}$ & $\begin{array}{r}+95, \% \\
\text { Cnf.Limt }\end{array}$ & Coeff. & $\begin{array}{l}\text { Std. Err. } \\
\text { Coeff. }\end{array}$ & $\begin{array}{c}-95, \% \\
\text { Cnf.Limt }\end{array}$ & $\begin{array}{r}+95, \% \\
\text { Cnf.Limt }\end{array}$ \\
\hline Mean/Interc. & 47.12500 & 0,791667 & 59,52632 & 0,000000 & 45,3341 & 48,91587 & 47,12500 & 0,791667 & 45,33413 & 48,91587 \\
\hline (1)Temperatura & 55,00000 & 1.583333 & 34,73684 & 0,000000 & 51,4183 & 58.58175 & 27,50000 & 0,791667 & 25,70913 & 29.29087 \\
\hline (2)Razão Molar & $-9,75000$ & 1,583333 & $-6,15789$ & 0,000167 & $-13,3317$ & $-6,16825$ & $-4,87500$ & 0,791667 & $-6,66587$ & $-3,08413$ \\
\hline (3)Tempo & 15,50000 & 1.583333 & 9.78947 & 0,000004 & 11,9183 & 19,08175 & 7.75000 & 0,791667 & 5,95913 & 9,54087 \\
\hline 1 by 2 & $-3,00000$ & 1,583333 & $-1,89474$ & 0,090648 & $-6,5817$ & 0,58175 & $-1,50000$ & 0,791667 & $-3,29087$ & 0,29087 \\
\hline 1 by 3 & 13.75000 & 1,583333 & 8.68421 & 0.000011 & 10,1683 & 17.33175 & 6,87500 & 0,791667 & 5.08413 & 8.66587 \\
\hline 2 by 3 & 0,00000 & 1,583333 & 0,00000 & 1,000000 & $-3,5817$ & 3,58175 & 0,00000 & 0,791667 & $-1,79087$ & 1,79087 \\
\hline
\end{tabular}

Figura 2.11 - Diagrama de pareto obtido do planejamento $2^{3}$ para as reações de produção de biodiesel de óleo de soja com etanol pressurizado.

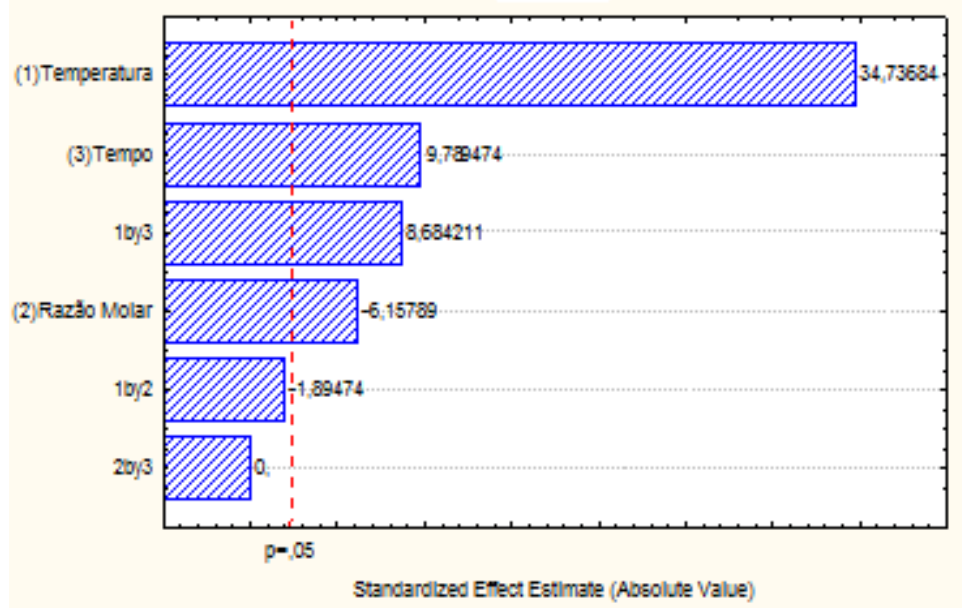

2.12 - Gráfico dos valores observados e dos valores obtidos do planejamento $2^{3}$ para a concersão das reações de produção de biodiesel com etanol pressurizado.

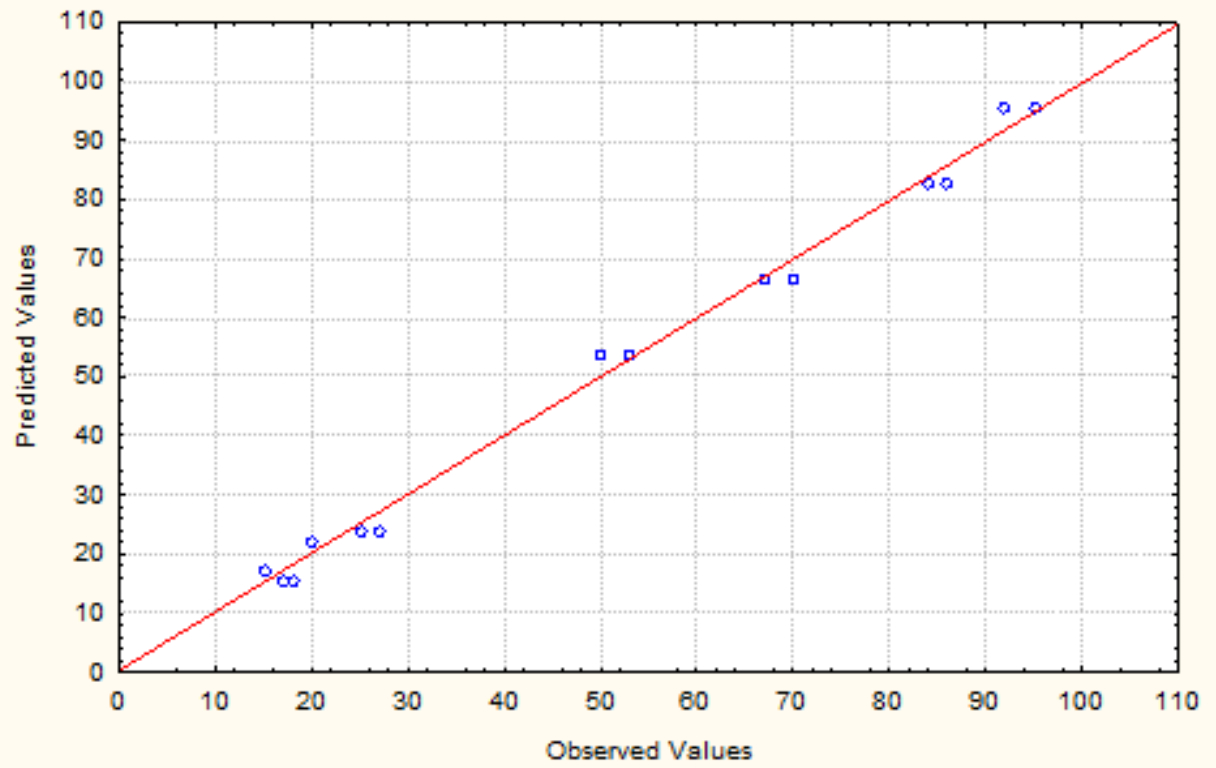


Figura 2.13 - Cubo que demonstra o planejamento $2^{3}$ para a conversão das reações de produção de biodiesel com etanol pressurizado.

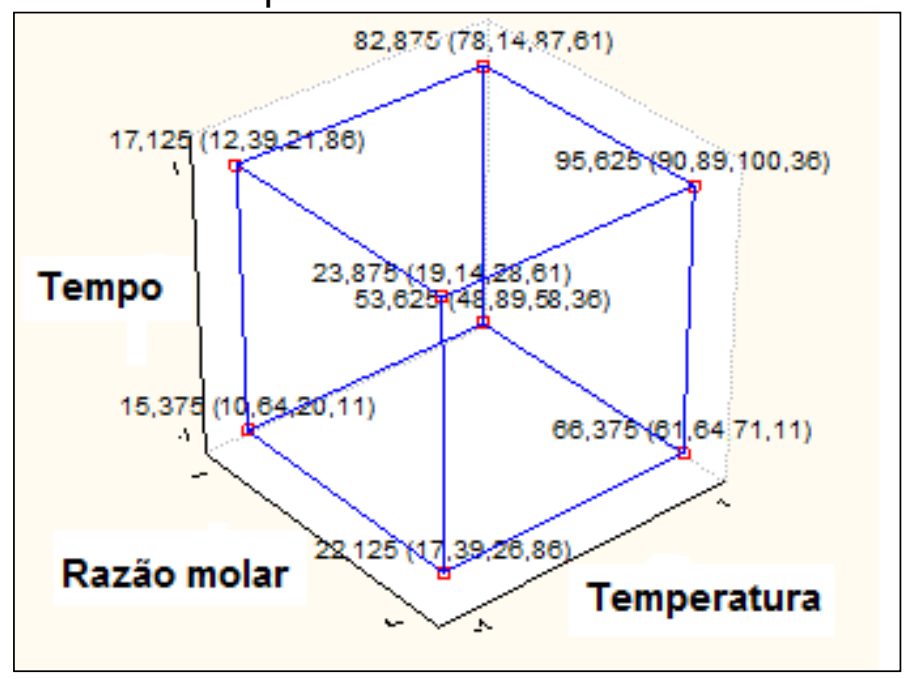

Pode-se concluir, por meio dos resultados obtidos que para reações de trasesterificação do óleo de soja com etanol pressurizado, que temperaturas supercríticas são necessárias para uma boa conversão, sendo que o melhor resultado obtido (95\%) foi alcançado em temperatura de $300^{\circ} \mathrm{C}$; razão molar Figura óleo/álcool de 1:10 e tempo de 1 hora. A pressão alcançada nessas condições foi de $250 \mathrm{~atm}$, os mesmos resultados encontrados para as reações metílicas. Como a pressão crítica para etanol é de 60,6 atm, conclui-se que para etanol também a maior conversão é alcançada no estado supercrítico. Tal resultado é de grande importância, pois indica que reatividade similares para o metanol e etanol foram alcançadas, e, portanto um mesmo procedimento experimental pode ser utilizado tanto para produção de biodiesel metílico quanto etílico. Além disso, prova-se que, nas condições experimentais estudadas, a razão molar de metanol e de etanol não são diferentes para uma conversão equivalente. Acredita-se que a pouca diferença das temperaturas críticas do metanol e etanol tenha ajudado na proximidade dos resultados encontrados.

Nos experimentos conduzidos com álcool em condições supercríticas, a temperatura é uma das variáveis mais investigadas. Comumente as reações de produção de biodiesel não catalítico em condições supercríticas são caracterizadas pela operação em elevadas temperaturas. Segundo ANITESCU et a ${ }^{48}$ quanto maior a temperatura mais semelhante ficam as condições entre o álcool e o óleo. Já foi reportado na literatura ${ }^{32}$ que em temperaturas menores do que $400^{\circ} \mathrm{C}$, a conversão 
dos triglicerídeos em ésteres metílicos pode ser reduzida. Porém, GUI et al ${ }^{3}, \mathrm{CAO}$ et $a{ }^{23}$, KUSDIANA et $a^{\beta 4}$, DEMIRBAS et $a^{\beta 8}$ e SILVA et $a l^{47}$ reportaram o favorecimento da reação inversa da transesterificação e a degradação térmica dos ésteres em temperaturas acima de $350^{\circ} \mathrm{C}$. Entretanto, não há trabalhos disponíveis na literatura que mostrem a variação de conversão de óleo de soja em biodiesel, em função do tempo, usando etanol supercrítico e regime de batelada. Observou-se nas reações metílica e etílica obtidas no presente trabalho que um grande aumento no rendimento da reação ocorreu quando se elevou a temperatura de sub para supercrítica.

Metanol e etanol líquidos, por serem solventes polares, possuem um maior poder de solvatação sob condições supercríticas, podendo solubilizar mais facilmente um óleo vegetal se for empregada temperatura e pressão apropriadas. Segundo CAO et $a^{23}$ os óleos vegetais em metanol supercrítico podem aumentar a solubilidade a uma taxa de $2-3 \%$ a cada $10^{\circ} \mathrm{C}$ aumentados até a temperatura da reação. Portanto, a explicação para o grande aumento na conversão da reação que ocorreu neste trabalho quando se elevou a temperatura de sub para supercrítica é devido a elevada solubilidade do metanol e etanol na fase óleo. Além disso, pode-se observar que nas condições supercríticas os produtos da reação são completamente solúveis nos álcoois, favorecendo também um aumento da taxa de conversão em ésteres.

De acordo com os resultados de estudos como o publicado por HEGEL et $a^{\beta 9}$, manter as temperaturas acima das temperaturas críticas dos compostos não é a única forma de promover a existência de fase única no meio reacional. A variação dos componentes também influencia no comportamento das fases. O efeito do rendimento da reação com a relação molar entre óleo e álcool é evidenciado na literatura de produção de biodiesel com álcoois supercríticos. ${ }^{34,38,47,49} \mathrm{Na}$ reações de transesterificação com álcool supercrítico é, geralmente, empregada uma alta razão molar de óleo vegetal para o álcool, normalmente em torno de 1:40. Esta elevada concentração de álcool faz com aumente a solubilidade entre as fases e o equilíbrio da reação se desloque para o sentido dos produtos (biodiesel), aumentando a conversão em ésteres da reação. Porém HE et $a^{{ }^{50}}$ constataram em seus estudos de transesterificação supercrítica contínua de óleo de soja e metanol, que a conversão aumenta até relações molares de 1:40 e que a partir deste valor o efeito na conversão é pouco pronunciado. 
Embora a motivação para o uso do estado supercrítico na produção de biodiesel resida no fato de se evitar a miscibilidade parcial da fase líquida (álcool/óleo) e de se obter uma fase homogênea da mistura reacional, em estudo recente HEGEL e colaboradores ${ }^{39}$ avaliaram o comportamento de fases da reação de transesterificação em meio supercrítico e constataram que para as diversas condições estudadas, mesmo com a adição de propano como co-solvente, a heterogeneidade do meio reacional persistia mesmo em temperaturas superiores à do ponto crítico do metanol. Os autores constataram altas conversões mesmo trabalhando em regiões bifásicas. Nestes casos, segundo os autores, é possível que a reação ocorra principalmente na fase leve, onde o óleo, os monoglicerídeos e os diglicerídeos encontram-se parcialmente solúveis e a concentração de álcool é maior, além disso, as propriedades de transporte da fase leve favorecem a taxa de reação. As constatações feitas no trabalho de HEGEL et al. ${ }^{39}$ mostram que, ao contrário do que se relata na literatura, a homogeneidade do sistema não é o efeito dominante para a melhora da taxa da reação de transesterificação em meio supercrítico.

Portanto, não existe na literatura um consenso sobre a influência da relação molar sobre o rendimento das reações em condições supercríticas. Observou-se, no presente trabalho, que razões molares menores óleo:álcool (1:10) favorecem a conversão da reação para os níveis avaliados. Sob o ponto de vista termodinâmico, esperar-se-ia que um aumento da concentração dos reagentes deslocasse o equilíbrio da reação e promovesse um aumento na conversão dos ésteres. Contudo, se a reação estiver próxima do equilíbrio, este excesso de álcool não induziria a maiores conversões.

Sob ótica cinética, o aumento na concentração de álcool pode levar a um aumento na taxa da reação, desde que a cinética dependesse da concentração deste reagente. Neste sentido, uma vez que no presente esquema reacional não existe solvente inerte, quando a concentração de álcool não contribuir na taxa de reação, o que se espera é um efeito de diminuição da concentração do reagente triglicerídico no meio reacional desfavorecendo, assim, a conversão da reação. Neste sentido, poder-se-ia argumentar que dentro da faixa experimental investigada, o regime cinético está dominando o regime termodinâmico e, neste balanço de forças, o aumento da quantidade de álcool reduziria a conversão da reação. Com relação ao comportamento das fases pôde-se observar que, a depender da razão 
molar inicial óleo/álcool, havia (para razões menores) ou não (para razões maiores) formação imediata de duas fases líquidas após a coleta da amostra.

No que se refere ao tempo, para as reações supercríticas os altos rendimentos são normalmente alcançados em baixos tempos de reação.

Segundo FREEDMAN et al. ${ }^{51}$ a composição química do álcool também interfere na reação de transesterificação, o processo ocorre preferencialmente com álcoois de baixo peso molecular ou constituídos por cadeias alquílicas menores, tais como metanol e etanol. Convencionalmente a produção de biodiesel metílica está mais consolidada em virtude das características físico-químicas do metanol, que apresenta cadeia mais curta e maior polaridade, assim como pela maior facilidade na separação das fases do produto da reação de transesterificação. ${ }^{11}$ Todavia, a produção de biodiesel empregando o etanol como agente transesterificante possui várias vantagens ambientais pois, ao contrário do metanol, o etanol é derivado da biomassa e é biodegradável. No presente trabalho, comparou-se o emprego de metanol e etanol em condições de processo similares. WARABE et al ${ }^{19}$ utilizaram vários tipos de álcoois, com temperatura de 300드. empregando uma razão molar álcool:óleo de 42:1, com diferentes pressões, e observaram que para um mesmo tempo de reação os álcoois com cadeias alquílicas menores apresentam uma melhor conversão. Porém, em nossos resultados observou-se um comportamento contrário ao apresentado na literatura, pois para igual tempo de reação, conversões próximas foram obtido para as reações com metanol e etanol.

Mediante resultado do planejamento experimental desenvolvido que mostrou que condições supercríticas de temperatura, baixas razões molares e altos tempos de reação são necessárias para uma boa conversão na produção de biodiesel não catalítico, procurou-se analisar a influência da adição de água ao meio reacional.

\subsection{A adição de água na reação}

KUSDIANA et $a f^{42}$ verificaram que a adição de água durante o processo de transesterificação com metanol supercrítico não influenciou na cinética da reação (Figura 2.14). Contudo, tornou a separação da glicerina dos ésteres muito mais fácil, pois como a glicerina é mais solúvel em água que em metanol, após a reação, a separação da glicerina foi realizada diretamente através de lavagens com água. Porém, TAN e colaboradores ${ }^{52}$ quando investigaram os efeitos da concentração de 
água no rendimento da reação na síntese de óleo de dendê com metanol supercrítico em um reator em batelada, mostraram que o rendimento da reação aumenta com o incremento no teor de água na mistura reacional.

Figura 2.14 - Efeito do teor de água sobre a conversão em ésteres metílicos: comparação entre metanol supercrítico ( $(\circ)$ e catálise homogênea básica (ロ) e ácida $(\mathbf{\Lambda})$.

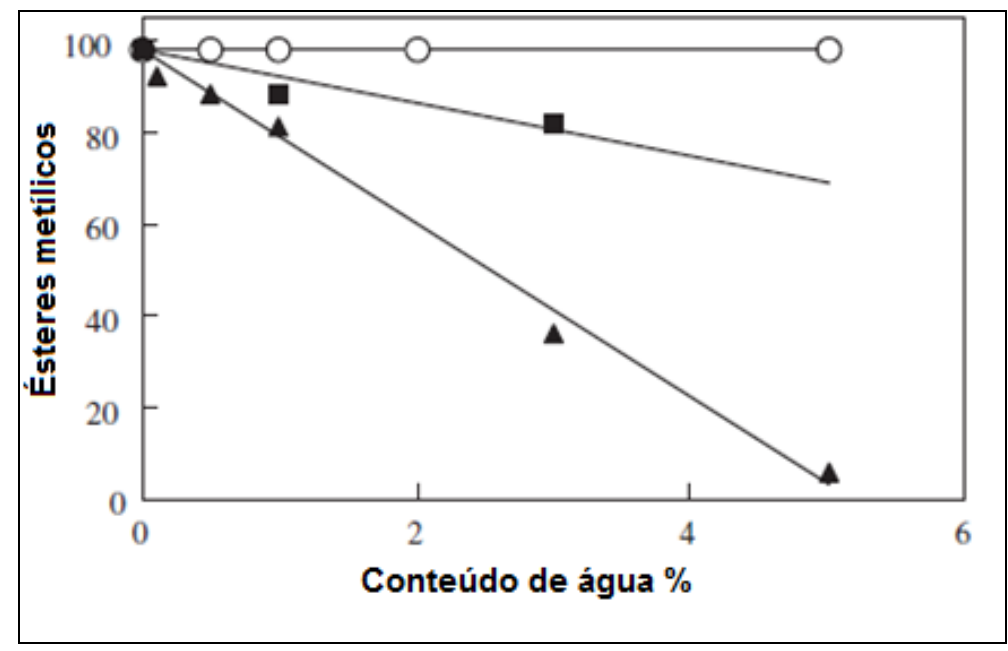

adaptado de KUSDIANA, D., SAKA, S. ${ }^{42}$

Os resultados obtidos no presente trabalho mostraram que a presença de água na proporção de 2,5 e 5\%, em relação a massa de óleo durante a reação de transesterificação com metanol supercrítico, influenciou levemente a formação de ésteres metílicos, ocorrendo um aumento de $95 \%$ para $98 \%$ na conversão da reação. Nas proporções de 7,5 e 10\% não foi observado diferença significativa nas conversões em ésteres, permanecendo constante. $O$ resultado pode ser explicado pelo fato de que uma certa quantidade de água melhora a formação de ésteres metílicos e etílicos pois, neste caso, três reações ocorrem simultaneamente o que contribui para o aumento no rendimento: transesterificação (Figura 2.15) e hidrólise de triglicerídeos seguida de esterificação dos ácidos graxos correspondentes (Figura 2.16).

Esterificação é a reação de um ácido carboxílico $(\mathrm{RCOOH})$ com um álcool $(\mathrm{ROH})$, para obtenção de éster (RCOOR). Na esterificação ocorre a ligação covalente entre as cadeias de ácido graxo e do álcool, com a formação de água em paralelo. 
Figura 2.15 - Figura demonstrando a hidrólise de triglicerídeos.

\begin{tabular}{|c|c|c|}
\hline $\mathrm{H}_{2} \mathrm{C}-\mathrm{OCOR}$ & Hidrólise & $\mathrm{R}^{\prime} \mathrm{COOH}$ \\
\hline $\mathrm{HC}-\mathrm{OCOR} "$ & $\frac{\Delta}{\mathrm{H}_{2} \mathrm{O}}$ & R" $\mathrm{COOH}$ \\
\hline $\mathrm{H}_{2} \mathrm{C}-\mathrm{OCOR} "$ & & $\mathrm{R}$ "'COOH \\
\hline Triglicerídeo & & Mistura de ácidos graxos \\
\hline
\end{tabular}

Figura 2.16 - Figura da reação de esterificação de um ácido graxo com metanol.

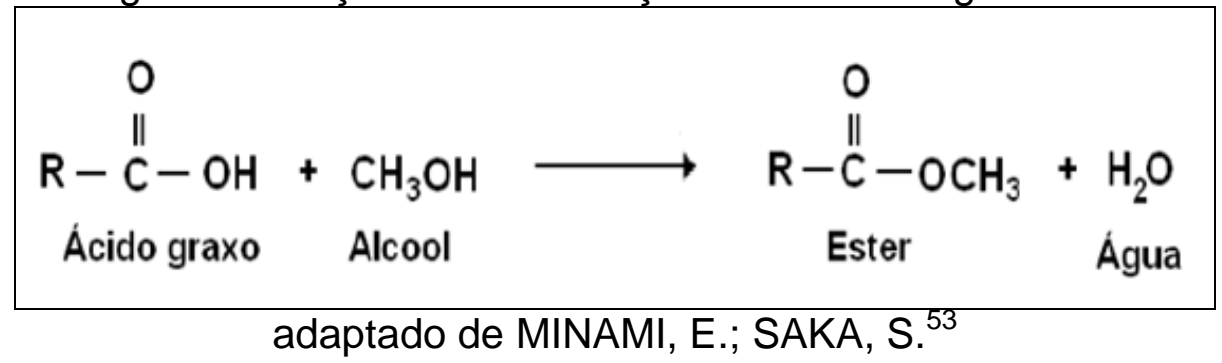

Por meio dos resultados obtidos neste trabalho, comparando-se com processos que usam catálise ácida ou alcalina, os quais sofrem influência negativa da presença de água, ficou demonstrado que na transesterificação supercrítica a presença de água altera positivamente a converso em ésteres da reação. Tal aspecto é altamente interessante uma vez que permite eliminar etapas de prétratamento da matéria prima como no caso dos processos convencionais catalíticos de produção.

\section{Conclusão}

Este trabalho teve por foco o estudo da produção em batelada de biodiesel de óleo de soja metílico e etílico pressurizados, avaliando-se a temperatura das reações, as razões molares óleo/ álcool e o tempo.

No tocante ao efeito das variáveis na reação de transesterificação em metanol e etanol pressurizados, podemos afirmar que o tempo foi a variável que mais beneficiou ambas reação dentro da faixa experimental investigada. Altas conversões foram alcançadas para metanol e etanol, nas condições supercríticas. As conversões de $95 \%$ a razões molares de $1: 10$, em tempos de 1 hora e $300^{\circ} \mathrm{C}$ demonstraram que o álcool (metanol ou etanol) utilizado não tem influencia direta na 
conversão de ésteres do processo supercrítico estudado, o que conduz a um aprimoramento do procedimento de síntese de biodiesel.

A partir dos resultados obtidos é possível concluir que a produção de biodiesel empregando metanol e etanol no estado supercrítico é uma tecnologia promissora. A principal vantagem deste processo é a simplificação das etapas de produção de biodiesel, quando comparado com o processo convencional. Esta simplificação ocorre em virtude da ausência de catalisador e processos de prétratamento do óleo vegetal para eliminação de água, pois verificou-se que a adição de determinadas quantidades de água ao sistema melhoram a conversão em ésteres para $98 \%$ ou não interferem na reação. De acordo com as normas da ANP, para ser classificado como biodiesel, a mistura de ésteres deve ter acima de $96 \%$ de ésteres, logo o biodiesel obtido com adição de 2,5 e 5\% (massa de água em relação a massa do óleo) está de acordo com a classificação brasileira.

Outra observação importante foi a diminuição do índice de iodo do biodiesel, o que confere ao combustível maior estabilidade química, diminuição da emissão de óxidos de nitrogênio (NOx). Além disso, a diminuição do índice de iodo pode trazer vantagens técnicas competitivas devido à possibilidade de adequar o biodiesel brasileiro na rigorosa especificação europeia.

\section{Sugestões para trabalhos futuros}

Diante dos resultados encontrados, sugere-se para trabalhos futuros os seguintes temas:

- Executar a reação de trasesterificação com álcool supercrítico de óleos vegetais com elevados índices de iodo e determinar a redução adequada deste parâmetro;

- Adição de cossolventes ao processo para investigar outras faixas de temperatura e pressão;

- Realizar estudo de viabilidade para a aplicação do processo em escala industrial, levando-se em conta aspectos técnicos, econômicos, ambientais e sociais;

- Estudo da cinética da reação e do comportamento de fases do meio reacional, contemplando a descrição da densidade da mistura e análise dos componentes;

- Acompanhar a produção de monoglicerídeos e diglicerídeos durante a reação, bem como acompanhar quimicamente possíveis produtos paralelos oriundos de reações de craqueamento. 


\section{Referências}

1 AGÊNCIA NACIONAL DO PETRÓLEO GÁS NATURAL E BIOCOMBUSTÍVEIS (ANP). Disponível em: <http://www.anp.gov.br/doc/legislacao/2004.pdf>. Acesso em: 04 jun. 2013.

2 ZANETTE, Andréia Fátima. Estudo da transesterificação do óleo de pinhão manso empregando catalisadores heterogêneos. 2010. 107f. Dissertação (Mestrado em Engenharia Química) - Departamento de Engenharia Mecânica Universidade Estadual do Oeste do Paraná, Toledo, 2010.

3 GUI, M.M; LEE, K.T; BHATIA, S. Supercritical ethanol technology for the production of biodiesel: Process optimization studies. The Journal of Supercritical Fluids, v. 49, n. 2, p. 286-292, 2009.

4 SUAREZ, P. A. Z.; MENEGHETTI, S. M. P. 70ํaniversário do biodiesel em 2007: evolução histórica e situação atual no Brasil. Química Nova, v. 30, n. 8, p. 20682071, 2007.

5 MA, F.; HANNA, M. Biodiesel production: a review. Bioresource Technology, v. 70, n. 1, p.1-15, 1999.

6 COSTA NETO, P. R.; ZAGONEL, L. F.; RAMOS, L. P. Produção de Biocombustível alternativo ao óleo diesel através da transesterificação de óleo de soja usado em frituras. Química Nova, v. 23, n. 4, p. 531-537, 2000.

7 VIANI, R.; BRAZ-FILHO, R. Ácidos graxos naturais: importância e ocorrência em alimentos. Química Nova, v. 19, n. 4, p. 400-407, 1996.

8 MENEGHETTI, S. M. P.; MENEGHETTI, M. R.; WOLF, C. R.; SILVA, E. C.; LIMA, G. E. S.; SILVA, L. L.; SERA, T. M.; CAUDURO, F.; OLIVEIRA, L. G. Biodiesel from castor oil: a comparision of ethanolysis versus methanolysis. Energy Fuels, v. 20, n. 5, p. 2262-2265, 2006.

9 GRIMALDI, R.; GONÇALVES, L. A. G.; ANDO, M. Y. Otimização da reação de interesterificação química do óleo de palma. Química Nova, v. 28, n.4, p. 633-636, 2005.

10 FERRARI, R. A.; OLIVEIRA, V. S.; SCABIO, A. Biodiesel de soja - taxa de conversão em ésteres etílicos, caracterização físico-química e consumo em gerador de energia. Química Nova, v. 28, n. 1, p. 19-23, 2005.

11 LIMA, J. R. O.; SILVA, R. B.; SILVA, C. C. M.; SANTOS, L. S. S.; SANTOS JR., J. R.; MOURA, E. M.; MOURA, C. V. R. Biodiesel de babaçu (Orbignya sp.) obtido por via etanólica. Química Nova, v. 30, n. 3, p. 600-603, 2007.

12 THORPE, S. C.; KEMENY, D. M. PANZANI, R. C.; McGURI, B.; LORD, M. Allrgy to castor bean seeds. Journal of Allergy and Clinical Immunology, v. 82, p. 67-72, 1988. 
13 SUJATHA, M.; REDDY, T. P.; MAHASI, M. J. Role of biotechnological interventions in the improvement of castor (Ricinus communis L.) and Jatropha curcas L. Biotechnology Advances, v. 26, n. 5, p. 424-435, 2008.

14 TEWARI, D. N. Jatropha and biodiesel. New Delhi : Oceans Books, 2007. $228 \mathrm{p}$.

15 SUAREZ, P. A. Z.; MENEGHETTI, S. M. P.; FERREIRA, V. F. O biodiesel e a política de C \& T brasileira. Quimica Nova, v. 29, n. 6, p. 1157-1158, 2006.

16 LEBEDEVAS, S.; VAICEKAUSKAS, A.; LEBEDEVA, G.; MAKAREVICIENE, V.; JANULIS, P.; KAZANCEV, K. Use of waste fats of animal and vegetable origin for the production of biodiesel fuel: quality, motor properties, and emissions of harmful components. Energy Fuels, v. 20, n. 5, p. 2274-2280, 2006.

17 CHISTI, Y. Biodiesel from microalgae. Biotechnology Advances, v. 25, n. 3, p. 294-306, 2007.

18 TORREY, M. Oil feedstocks \& environmental algae inn the thank. Tribology \& Lubrication Technology, v. 64, n. 12, p. 26-32, 2008.

19 WARABI, Y., KUSDIANA, D.; SAKA, S. Reactivity of triglycerides and fatty acids of rapeseed oil in supercritical alcohol. Bioresource Technology, v. 91, n. 3, p. 283287, 2004.

20 OLIVEIRA, J.V. e OLIVEIRA, D. Kinetics of the enzymatic alcoholysis of palm oil in supercritical $\mathrm{CO}_{2}$. Industrial \& Engineering Chemistry Research, v. 39, n. 12, p. 4450-4454, 2000.

21 ISO, M.; CHEN, B.; EGUCHI, M.; KUDO, T.; SHRESTHA, S. Production of biodiesel fuel from triglycerides and alcohol using immobilized lipase. Journal of Molecular Catalysis B: Enzymatic, v. 16, n. 1, p. 53-58, 2001.

22 MARCHETTI, J.M.; MIGUEL, V.U.; ERRAZU, A.F. Possible methods for biodiesel production. Renewable and Sustainable Energy Reviews, v.11, n. 6, p. 13001311, 2007.

$23 \mathrm{CAO}$, W.; HAN, H.; ZHANG, J. Preparation of biodiesel from soybean oil using supercritical methanol and co-solvent. Fuel, v. 84, n. 4, p. 347-351, 2005.

24 DEMIRBAS, A. Studies on cottonseed oil biodiesel prepared in non-catalytic SCF conditions. Bioresourde Technology, v. 99, n. 5, p. 1125-1130, 2008.

25 SHIN, H-Y.; LEE, S-H.; RYU, J-H. Biodiesel production from waste lard using supercritical methanol. The Journal of Supercritical fluids, v. 61, p. 134-138, 2013.

26 ANIKEE, V. I.; YAKOVLEVA, E. Y. Biodiesel synthesis from vegetable oils with supercritical methanol. The Journal of Supercritical fluids, v. 77, p. 100-102, 2013. 
27 LEE, S.; POSARAC, D.; ELLIS, N. An experimental investigation of biodiesel synthesis from waste canole oil using supercritical methanol. Fuel, v. 91, n. 1, p. 229237, 2012.

28 HAN, H. W.; CAO, W. L.; ZHANG, J. C. Preparation of biodiesel from soybean using methanol. Process Biochemistry, v. 40, n. 9, p. 3148-3152, 2005.

29 YIN, J-Z.; XIAO, M.; SONG, J-B. Biodiesel from soybean oil in supercritical methanol with co-solvent. Energy Conversion and Management, v. 49, n. 5, p. 908912, 2008.

30 HAWASH, S.; KAMAL, N.; ZAHAS, F.; KANAWI, O.; El- DINAWI, G. Biodiesel fuel from jarthropa oil via non-catalytic supercritical transesterification. Fuel, v. 88, n. 10, p. 579-582, 2009.

31 BARROS NETO, B.; SCARMINIO, I. S.; BRUNS, R. E. Planejamento e otimização de experimentos. Campinas :Editora Unicamp, 1996. 299 p.

32 MADRAS, G.; KOLLURU, C.; KUMAR, R. Synthesis of biodiesel in supercritical fluids. Fuel, v. 83, n. 14-15, p. 2029-2033, 2004.

33 FREEDMAN, B.; PRYDE, E. H.; MOUNTS, T. L. Variables affecting the yields of fatty esters from transesterified vegetable oils. Journal of the American Oil Chemists' Society, v. 61, n. 10, p. 1638-1643, 1984.

34 KUSDIANA, D.; SAKA, S. Methyl esterification of free fatty acids of rapeseed oil as treated in supercritical methanol. Chemical Engineering of Japan, v. 34, n. 3, p. 383-387, 2001.

35 WEN, D.; JIANG, H.; ZHANG, K. Supercritical fluids technology for clean biofuel production. Progress in Natural Science, v. 19, n. 3, p. 273-284, 2009.

36 KUSDIANA, D., SAKA, S. Kinetics of transesterification in rapeseed oil to Biodiesel fuel as treated in supercritical methanol. Fuel, v. 80, n. 5, p. 693-698, 2001.

37 DEMIRBAS, A. Biodiesel from vegetable oils via transesterification in supercritical Methanol. Energy Conversion \& Management, v. 43, n. 17, p. 2349-2356, 2002.

38 DEMIRBAS, A. Biodiesel fuels from vegetable oils via catalytic and non-catalytic supercritical alcohol transesterifications and other methods: a survey. Energy Conversion and Management, v. 44, n. 13, p. 2093 - 2109, 2003.

39 HEGEL, P.; MABE, G.; PEREDA, S.; BRINGNOLE, E.A. Phase transitions in a biodiesel reactor using supercritical methanol. Industrial \& Engineering Chemistry Research, v. 46, n. 19, p. $6360-6365,2007$.

40 SCHUCHARDT, U.; SERCHELI, R.; VARGAS R.M. Transesterification of vegetable oils: a review. Journal of Brazilian Chemical Society, v. 9, n. 1, p.199210, 1998. 
41GERIS, R.; SANTOS, N. A. C.; AMARAL, B. A.; MAIA, I. S.; CASTRO, V. D.; CARVALHO, J. R. M. Biodiesel de soja - reação de transesterificação para aulas práticas de química orgânica. Química Nova, v. 30, n. 5, p. 1369-1373, 2007.

42 KUSDIANA, D.; SAKA, S.; Effects of water on biodiesel fuel production by supercritical metanol treatment. Bioresource Technology, v. 91, n. 3, p. 289-295, 2004.

43 KRAMMER, P.; VOGEL, H. 2000. Hydrolysis of esters in subcritical and supercritical water. The Journal of Supercritical fluids, v. 16, n. 3, p. 189-206, 2000.

44 SANTOS, Wilson Linhares. Produção não catalítica de biodiesel etílico em meio supercrítico contínuo com e sem cossolvente. 2009. 83 f. Dissertação (Doutorado em Engenharia de Processos) - Universidade Tiradentes, Aracajú, Sergipe, 2009.

45 NETO, P. R. C.; ROSSI, L. F. S.; ZAGONEL, G. F.; RAMOS, L. P. Produção de biocombustível alternativo ao óleo de soja usado em frituras. Química Nova. v. 23, n. 4 , p. $531-537,2000$.

46 PINTO, A. C.; GUARIEIRO, L. L. N.; REZENDE, M. J. C.; RIBEIRO, N. M.; TORRES, E. A.; LOPES, W. A.; PEREIRA, P. A. P.; ANDRADE, J. B. Biodiesel: na overview. Journal of The Brazilian Chemical Society, v. 16, n. 6, p. 1313-1330, 2005.

47 SILVA, C.; WESCHENFELDER, T. A.; ROVANI, S.; CORAZZA, F. C.; CORAZZA, M. L.; DARIVA, C.; OLIVEIRA, J. V. Continuous production of fatty acid ethyl esters from soybean oil in compressed ethanol. Industrial Engineering Chemistry Research, v. 46, n. 16, p. 5304-5309, 2007.

48 ANISTESCU, G.; DESHPANDE, A.; TAVLARIDES, L.L. Integrated technology for supercritical biodiesel production and power cogeneration. Energy \& Fuel, v. 22, n. 2, p. 1391-1399, 2008.

49 VIEITEZ, I.; SILVA, C.; ALCKMIN, I.; BORGES, G. R.; CORAZZA, F. C.; OLIVEIRA, J. V.; GROMPONE, M. A.; JACHMANIÁN, I. Effect of temperature on the continuous synthesis of soybean esters under supercritical ethanol. Energy \& Fuels, v. 23, n. 1, p. 558-563, 2008.

$50 \mathrm{HE}, \mathrm{H} . ;$ TAO, W.; ZHU, S. Continuous production of biodiesel from vegetable oil using supercritical methanol process. Fuel, v. 86, n. 3, p. 442-447, 2007.

51 FREEDMAN, B.; BUTTERFIELD, R. O.; PRYDE, E.H. Transesterification kinetics of soybean oil. Journal of The American Oil Chemists' Society, v. 63, n. 10, p. 1375-1380, 1986.

52 TAN, K.T.; LEE, K.T.; MOHAMED, A.R. Effects of free fatty acids, water content and co-solvent on biodiesel production by supercritical methanol reaction. The Journal of Supercritical Fluids, v. 53, n. 1-3, p. 89-91, 2010. 
53 MINAMI, E.; SAKA, S.Kinetics of hydrolysis and methyl esterification for biodiesel production in two-step supercritical methanol process. Fuel, v. 85 , n. 17-18, p. 24792483, 2006. 


\section{CAPÍTULO III}

\section{Análise química em bioenergia - aperfeiçoamento de metodologia de caracterização de acilgliceróis em biodiesel utilizando HRGC}




\section{Introdução}

\subsection{Regulamentação do Biodiesel}

A Áustria foi o primeiro país a definir e aprovar os padrões de qualidade para biodiesel, aplicados a ésteres metílicos de colza. Subsequentemente, padrões de qualidade foram sendo estabelecidos em outros países. ${ }^{1}$ Atualmente o padrão de qualidade americano, elaborado pela ASTM (American Society of Testing and Materials), através da norma ASTM D6751, e o estabelecido na União Européia através da norma EN 14214 do Comitê Europeu de Normalização (Comité Européen de Normalisation - CEN) figuram como os mais conhecidos e são geralmente usados como referência ou base para outros padrões ${ }^{2}$, enquanto no Brasil o mesmo é feito através da resolução ANP 07/2008.

O biodiesel no Brasil tem histórico recente em termos de metas do programa nacional para sua produção. A partir da edição da Portaria 255/2003 pela então chamada Agencia Nacional de Petróleo ANP, ficou preliminarmente definida a especificação do biodiesel a ser utilizado no Brasil, em mesclas com óleo diesel em até $20 \%$, atendendo as seguintes premissas:

a. Especificar o biodiesel puro, para uso em misturas ate $20 \%$ com diesel de petróleo;

b. Tomar por base as propriedades do combustível, independentemente da matéria-prima utilizada;

c. Basear-se na especificação do óleo diesel, eliminando as características não aplicáveis e incluindo as particularidades do biodiesel;

d. Procurar alinhar-se a experiência internacional.

A especificação e o método adotados (ASTM D-6751) foram similares aos empregados pelo Conselho Nacional Americano de Biodiesel (CNAB) e a norma europeia (EN 14214), entretanto deixando como parâmetros livres, para serem anotados, a viscosidade (a mistura de $20 \%$ de biodiesel ao diesel de petróleo deve atender a especificada para o diesel) e o índice de iodo (indicador do numero de ligações duplas e, portanto do nível de instauração do biodiesel). Isto visa não criar obstáculos a utilização de algumas matérias-primas, como a mamona (alta viscosidade) ou soja e girassol (alto teor de acido linoleico, polinsaturado e, portanto com alto numero de iodo).

Em 2004, a definição de Biodiesel como combustível foi feita pela Regulamentação Técnica ANP n 4/2004 como o combustível composto de alquil 
ésteres de ácidos graxos oriundos de óleos vegetais ou gorduras animais. Por intermédio da Resolução 42, a ANP especificou propriedades para o biodiesel comercializado no país, bem como, as técnicas analíticas para a sua caracterização. Entre as propriedades, essa resolução determinava a quantificação do teor de ésteres graxos, isto é, a pureza do biodiesel, sem, entretanto, fixar valor mínimo. O método cromatográfico com padronização interna e calibração por um ponto, descrito na norma europeia EN14103, foi adotado como técnica quantitativa. (EN14103:2003; Fatty acid methyl esters (FAME) - Determination of ester and linolenic acid methyl esters contents, European Committee for Standardization: Brussels, 2003). Porém, o biodiesel só foi introduzido na matriz energética pela Lei 11.097, de 13 de janeiro de 2005, determinando a sua obrigatoriedade de uso em mistura com o diesel fóssil na proporção de $2 \%$ a partir de 2008 . Por esta lei foi instituída a Agência Nacional de Petróleo, Gás Natural e Combustível (ANP) que, entre outras atribuições, é responsável pela especificação do biodiesel. Posteriormente, em março de 2008, a ANP publicou a Resolução oo 7 que estabelece $96,5 \%$ como a pureza mínima do biodiesel e aumenta a obrigatoriedade da adição de biodiesel no diesel para $3 \%$ a partir de julho daquele ano. ${ }^{3}$

\subsection{Especificações e controle de qualidade do Biodiesel}

A especificação de um combustível para uso comercial é considerada uma etapa essencial para sua adequada introdução no mercado, pois deve compatibilizar e harmonizar interesses muitas vezes contraditórios entre produtores do combustível, fabricantes de motores e de sistemas associados, além de órgãos ambientais, dentro de limites tecnológicos e econômicos. Neste contexto, para garantir a qualidade do biodiesel é necessário, estabelecer padrões de qualidade, objetivando fixar teores limites dos contaminantes que não venham prejudicar a qualidade das emissões da queima, bem como o desempenho, a integridade do motor e a segurança no transporte e manuseio.

A qualidade do biodiesel pode sofrer variações conforme as estruturas moleculares dos seus ésteres constituintes ou devido à presença de contaminantes oriundos da matéria prima, do processo de produção ou formados durante a estocagem do biodiesel. As estruturas moleculares dos ésteres podem variar tanto no tamanho da cadeia carbônica, quanto na quantidade e posição de insaturações ou mesmo devido à presença de agrupamentos na cadeia. 
Dependendo da eficiência do processo de produção e/ou purificação do biodiesel, além da mistura de ésteres, podem estar presentes em maior ou menor quantidade: glicerina livre, glicerídeos não reagidos (mono, di e triglicerídeos), sabões, álcool residual, resíduos de catalisadores e água. Entre as características e especificações do biodiesel está, portanto a análise de glicerina livre (termo definido como traços de glicerina dissolvida no biodiesel) e glicerina ligada (mono, di e triglicerídeos), além do teor de ésteres.

A presença da glicerina livre no biodiesel gera uma série de problemas, principalmente na armazenagem, no sistema de injeção de combustível dos automotores devido à separação da glicerina. A glicerina livre é associada, também com depósitos no fundo dos tanques de combustível atraindo outros contaminantes como água, aumentando assim a corrosão do motor e diminuindo a sua vida útil. $\mathrm{A}$ glicerina livre tem um limite máximo permitido de 0,02\% em massa de biodiesel, estabelecido pela Resolução $n^{\circ} 42 / 2004$ da $\mathrm{ANP}^{3}$. A previsão é que esse limite máximo seja reduzido ainda mais, forçando o desenvolvimento de métodos analíticos de alta sensibilidade para a determinação da concentração desse composto no biodiesel.

A presença de mono, di e triglicerídeos aumenta a viscosidade do biodiesel, reduzindo o efeito spray na injeção, dificultando a combustão e induzindo a carbonização dos cilindros. Para a melhor fiscalização das amostras de biodiesel é necessário um método rápido que permita a total caracterização do biodiesel (identificação e quantificação).

\subsection{Métodos Analíticos para avaliação da qualidade do biodiesel - Avaliação do processo produtivo}

$\mathrm{Na}$ Tabela 3.1 estão descritos e detalhados os parâmetros de avaliação do biodiesel. As especificações do Método D-6751 da ASTM servem de referência para identificar os padrões que o biodiesel (B100) precisa atender, antes de ser usado como combustível ou ser misturado ao petrodiesel. A ASTM recomenda método D-6582 para a análise de glicerina em combustível por Cromatografia Gasosa (CG). 
Tabela 3.1 - Descrição dos vários parâmetros empregados atualmente para especificação do biodiesel. ${ }^{3}$

\begin{tabular}{|c|c|c|c|c|c|c|c|}
\hline \multirow[b]{2}{*}{ Parâmetro } & \multirow[b]{2}{*}{ Efeito } & \multirow[b]{2}{*}{ Equipamento } & \multirow[b]{2}{*}{ Especificação } & \multirow{2}{*}{$\begin{array}{l}\text { Unidade } \\
\text { medida }\end{array}$} & \multicolumn{3}{|c|}{ Normalização } \\
\hline & & & & & $\begin{array}{l}\text { ABNT } \\
\text { NBR }\end{array}$ & ASTM D- & EN ISO- \\
\hline Teor de ésteres & $\begin{array}{l}\text { Falhas de queima e } \\
\text { acúmulo de resíduos }\end{array}$ & $\begin{array}{c}\text { Cromatógrafo } \\
\text { gasoso }\end{array}$ & 96,5\% (mín.) & $\%$ massa & 15342 & ------ & EN14103 \\
\hline Glicerina livre & $\begin{array}{l}\text { Depósitos carbônicos e } \\
\text { acúmulo de resíduos }\end{array}$ & $\begin{array}{c}\text { Cromatógrafo } \\
\text { gasoso }\end{array}$ & 0,02 (máx.) & $\%$ massa & 15341 & 6584 & $\begin{array}{c}\text { EN14105 } \\
14106\end{array}$ \\
\hline Glicerina Total & $\begin{array}{c}\text { Depósitos carbônicos e } \\
\text { acúmulo de resíduos }\end{array}$ & $\begin{array}{c}\text { Cromatógrafo } \\
\text { gasoso }\end{array}$ & 0,25 (máx.) & $\%$ massa & 15344 & 6584 & EN14105 \\
\hline $\begin{array}{l}\text { Mono, di e } \\
\text { triglicerídeos }\end{array}$ & $\begin{array}{l}\text { Depósitos carbônicos, } \\
\text { acúmulo de resíduos e } \\
\text { formação de sabões }\end{array}$ & $\begin{array}{l}\text { Cromatógrafo } \\
\text { gasoso }\end{array}$ & $\begin{array}{l}\text { Varia bastante } \\
\text { e quanto } \\
\text { menor melhor }\end{array}$ & $\%$ massa & $\begin{array}{l}15342 / \\
15344\end{array}$ & 6584 & EN14105 \\
\hline $\begin{array}{l}\text { Álcool metílico } \\
\text { (ou etílico) }\end{array}$ & $\begin{array}{l}\text { Abaixamento do ponto de } \\
\text { fulgor, danos no motor e } \\
\text { perda de rendimento e } \\
\text { potência no motor }\end{array}$ & $\begin{array}{c}\text { Cromatógrafo } \\
\text { gasoso }\end{array}$ & $\begin{array}{l}\text { 0,5\% massa } \\
\text { (máx.) }\end{array}$ & $\%$ massa & 15343 & ------ & EN14110 \\
\hline
\end{tabular}




\subsubsection{Glicerina livre e total}

Tanto no Brasil, quanto na Europa e nos Estados Unidos, o teor máximo permitido de glicerina livre no biodiesel é de $0,02 \%$ massa e a sua determinação é realizada através dos métodos cromatográficos EN ISO 14105 e EN ISO 14106, estabelecidos pela norma européia, e o método ASTM D6584, pela norma americana. Esses métodos de análise também foram adotados pela norma brasileira, havendo ressalva quanto à necessidade de validação para biodieseis de matérias primas não previstas nos métodos e proveniente da rota etílica. Para biodieseis de misturas de matérias primas distintas, onde faça parte o óleo de mamona, a RANP 07/08 recomenda o método ABNT NBR 15341.

A glicerina combinada pode ser calculada a partir das concentrações de mono-, di- e triglicerídeos, aplicando-se fatores de conversões individuais baseados na massa molar média dos ácidos graxos que participam da composição da matéria prima. A soma da concentração da glicerina livre com a glicerina combinada é denominada como glicerina total. Quanto ao teor de glicerina total, a norma brasileira e a européia estabelecem um limite máximo de 0,25\% massa, enquanto nos Estados Unidos o limite é de 0,24\% massa.

Atualmente a cromatografia a gás em altas temperaturas (High temperature gas chromatography - HTGC) é a técnica cromatográfica mais utilizada para análise de glicerina livre e total em biodiesel. Os métodos analíticos americano e europeu foram desenvolvidos para análise de glicerina livre e total, tendo como base biodieseis metílicos de soja (ASTM D6584), canola e girassol (EN ISO 14105), respectivamente. No mundo, grande parte do biodiesel produzido em escala comercial é proveniente da rota metílica e, em maior parte, originário da soja ou canola. No Brasil, existe uma grande variedade de matérias primas que podem ser utilizadas na produção do biodiesel, além do uso da rota etanólica que pode ser implementada. Neste caso, torna-se premente a validação dos métodos analíticos ou o desenvolvimento de novos métodos de determinação de glicerina livre e total para biodieseis de diferentes matérias primas e rotas de transesterificação. Tanto a norma européia como a americana utilizam a HTGC para determinação de glicerina livre e glicerídeos não reagidos em biodiesel. Esses métodos são recomendados pela norma brasileira para análise de biodiesel. Quanto à análise de glicerina total em biodieseis de misturas de matérias primas distintas, onde faça parte o óleo de mamona, a RANP 07/08 recomenda o método ABNT NBR 15344. 


\section{Objetivos Específicos}

Está incluso entre os objetivos desta etapa do trabalho aperfeiçoar e melhorar a análise de gliceróis em amostras de biodiesel por meio da técnica analítica HRGC apropriada.

\section{Procedimento Experimental}

Para o desenvolvimento da metodologia analítica de análise de mono, di e triglicerídeos em amostras de biodiesel é importante ressaltar que se partiu do pressuposto de que o biodiesel esteja dentro das especificações brasileiras (estabelecidas pela ANP), para posteriormente ser fortificada com adição de padrões. Para isso, neste trabalho também foi produzido biodiesel metílico e etílico com aproximadamente $100 \%$ de pureza.

\subsection{Produção de biodiesel}

Biodiesel de óleo de soja refinado (Cargill, Mairinque, Brasil) foi produzido por transesterificação catalisada por base. Um resumo deste procedimento é apresentado a seguir:

Aqueceu-se, com agitação magnética moderada (agitador magnético, Fanem, São Paulo, Brasil), $20 \mathrm{~mL}$ de óleo vegetal. Quando a temperatura atingiu 60 ${ }^{\circ} \mathrm{C}$ foram adicionados a $10 \mathrm{~mL}$ de solução $2 \%$ de $\mathrm{NaOH}$ (Mallinckrodt, Xalostoc, México) (relação a massa do óleo) em etanol anidro (J.T. Baker, Phillipsburg, USA) ou $8 \mathrm{~mL}$ de solução $2 \%$ de $\mathrm{NaOH}$ em metanol secado (J.T. Baker, Phillipsburg, USA). A mistura foi mantida durante 30 minutos, sempre a $60^{\circ} \mathrm{C}$ e com agitação mecânica constante (200 rpm). Em seguida a mistura foi transferida para um funil de separação, onde observou-se a formação de duas fases; deixou-se decantar durante 24 horas. Logo após as 24 horas descartou-se a fase inferior (fase inorgânica), composta de glicerol, sabões, excesso de base e álcool, mais densa e mais escura, e lavou-se a fase superior (fase orgânica), menos densa e mais clara, contendo ésteres com água acidificada (ácido acético $0,05 \mathrm{~mol} \mathrm{~L}^{-1}$ (Mallinckrodt, Xalostoc, México) quente (aproximadamente $70^{\circ} \mathrm{C}$ ). Lavou-se a solução com um volume de água acidificada de aproximadamente três vezes o volume de óleo inicial utilizado. Verificou-se o pH da solução com papel indicador (Merck, Darmstadt, Alemanha). As lavagens aquosas a quente de ácido proporcionam a retirada de impurezas e a ausência do catalisador básico foi confirmada através da medida do $\mathrm{pH}$ da solução, a qual deve estar neutra. Após a solução ser lavada, aqueceu-se a $100{ }^{\circ} \mathrm{C}$ durante 
60 minutos para eliminação de água e álcool. Como última etapa do procedimento seguiu-se para filtragem da amostra. Esta transeterificação foi realizada segundo uma adaptação do método descrito por Christie. ${ }^{4}$

O óleo de soja utilizado para realização da reação de transesterificação foi o óleo de soja refinado. O emprego de óleo de soja refinado elimina o efeito causado pelos componentes não glicerídicos, presentes nos óleos vegetais nãorefinados, sobre o rendimento da reação de transesterificação. ${ }^{5}$

Observou-se que no momento da ocorrência da reação há uma brusca mudança na cor da mistura, sendo esta escurecida e logo após retornando à coloração inicial. Normalmente a alcoólise alcalina de óleos vegetais é conduzida a temperatura próxima do ponto de ebulição do álcool e a temperatura está correlacionada com o tempo de reação. ${ }^{6}$ Temperaturas de reação acima de $60{ }^{\circ} \mathrm{C}$ devem ser evitada, pois esta tende a acelerar a saponificação dos glicerídeos pelo catalisador alcalino antes da completa alcoólise. Logo, a temperatura de aproximadamente $60 \stackrel{\circ}{\circ}$ foi adotada de modo a se obter uma conversão satisfatória de ésteres, não ultrapassando a temperatura do ponto de ebulição dos álcoois.

Todos os ensaios foram realizados em triplicata.

Os óleos vegetais utilizados como matéria prima para a produção de biodiesel foram previamente analisados por HRGC para determinação da composição de triglicerídeos presentes.

A conversão das reações também foi avaliada por HRGC, para confirmação de que apenas ésteres foram formados.

\subsection{Análises das amostras de biodiesel produzidas}

A análise de mono, di e triglicerídeos por HRGC foi utilizada para verificar a conversão final do óleo em ésteres.

Realizou-se as análises cromatográficas dos produtos das transesterificações metílicas e etílicas em catálise básica na concentração de 1,0 $\mathrm{mg} / \mathrm{mL}$ Para as análises utilizou-se um Cromatógrafo a Gás Shimadzu modelo GC2010 (Shimadzu, Kyoto, Japão) equipado com um detector de ionização de chama FID a $380^{\circ} \mathrm{C}$ e um injetor "split" a $360^{\circ} \mathrm{C}$. Utilizou-se um volume de injeção de $1 \mu \mathrm{L}$ para uma razão de "split" de 1:30. Utilizou-se $N_{2}$ como gás auxiliar e hidrogênio como gás de arraste a uma velocidade linear média de $60 \mathrm{~cm} \mathrm{~s}^{-1}$. Utilizou-se colunas 
apolares NST-5-HT (5\%fenil, 95\%metilpolisiloxano) com dimensões (10 m X 0,25 $\mathrm{mm} \times 0,08 \mu \mathrm{m}$ ) e programação de temperatura descrita na Tabela 3.2.

Tabela 3.2 - Programação de temperatura do forno da coluna para análises do biodiesel produzido.

\section{Programação de temperatura do forno da coluna}

\begin{tabular}{ccc}
\hline Temperatura Inicial & $150^{\circ} \mathrm{C}$ & Permanência de $10 \mathrm{~min}$. \\
Rampa 1 & $10^{\circ} \mathrm{C} / \mathrm{min}$ até $200^{\circ} \mathrm{C}$ & Permanência de $5 \mathrm{~min}$. \\
Rampa 2 & $7^{\circ} \mathrm{C} / \mathrm{min}$ até $260^{\circ} \mathrm{C}$ & \\
Rampa 3 & $5^{\circ} \mathrm{C} / \mathrm{min}$ até $297^{\circ} \mathrm{C}$ & Permanência de $2 \mathrm{~min}$. \\
Rampa 4 & $5^{\circ} \mathrm{C} / \mathrm{min}$ até $370^{\circ} \mathrm{C}$ & Permanência de $5 \mathrm{~min}$.
\end{tabular}

A identificação dos picos foi feita com base na comparação com tempo de retenção de padrões analíticos nas mesmas condições cromatográficas das análises.

A identificação dos picos foi feita com base na comparação com tempo de retenção de padrões analíticos nas mesmas condições cromatográficas das análises.

\subsection{Preparação das amostras para análise do desenvolvimento da metodologia de análise}

Foram preparadas soluções contendo $1,0 \mathrm{mg} \mathrm{mL}^{-1}$ de biodiesel de soja em $\mathrm{n}$-hexano e também soluções de $10 \mathrm{mg}$ de biodiesel de soja fortificadas com 1 mg de monoleína (Sigma-Aldrich, Saint Louis, EUA) dioleína (Sigma-Aldrich, Saint Louis, EUA), trioleína (Sigma-Aldrich, Saint Louis, EUA) e tricaprina (Sigma-Aldrich, Saint Louis, EUA) em $10 \mathrm{~mL}$ de n-hexano.

\subsection{Desenvolvimento da metodologia para análise por HRGC}

Com o objetivo de aperfeiçoar a metodologia de análise de glicerol livre, mono, di e triglicerídeos, modificações foram realizadas no método normalizado pela ANP no 42 para este tipo de análise. 
Para obtenção dos cromatogramas, utilizou-se um cromatógrafo a Gás Shimadzu modelo GC-2010 (Shimadzu, Kyoto, Japão) equipado com um detector de ionização de chama FID a $370{ }^{\circ} \mathrm{C}$ e um injetor a $350 \stackrel{\circ}{\circ} \mathrm{C}$. As injeções foram realizadas por introdução mecânica e o volume de injeção correspondeu a $1 \mu \mathrm{L}$ com modo de injeção "splitless" por meio minuto. Utilizou-se $\mathrm{N}_{2}$ como gás auxiliar e hidrogênio como gás de arraste a uma velocidade linear média de $22,5 \mathrm{~cm} \mathrm{~s}^{-1}$. Utilizou-se coluna apolar NST-5-HT (5\%fenil, 95\%metilpolisiloxano) com dimensões (30 $\mathrm{m} \times 0,25 \mathrm{~mm} \times 0,1 \mu \mathrm{m}$ ) e realizou-se a diferentes programações de temperatura. As amostras introduzidas foram de biodiesel de soja metílico e etílico normal e fortificado.

Foi realizado uma série de programações de temperaturas de forno diferentes e obtido o resultado considerado satisfatório.

A identificação dos picos foi feita com base na comparação com tempo de retenção de padrões analíticos e a quantificação por padronização interna e externa. Também nessa etapa as análises foram realizadas em quintuplicata.

\subsection{Parâmetros analisados para a avaliação do desempenho da metodologia - Parâmetros de Validação}

O processo de validação de um método verifica, por meio de estudos laboratoriais, se suas características de desempenho estão de acordo com as especificações apresentadas para a intenção do uso dos resultados analíticos. Assim, as características de desempenho determinadas foram: estudo da linearidade do método e precisão. ${ }^{7}$

As faixas lineares foram estabelecidas pelo método ASTM D 6584. Cada nível de concentração foi injetado 3 vezes no sistema cromatográfico desenvolvido neste trabalho. A linearidade do método para cada composto foi avaliada pelo coeficiente de determinação $\left(r^{2}\right)$, após a construção da curva analítica.

\subsubsection{Curva analítica, linearidade e determinação da quantidade de mono, di e triglicerídeos}

Foram preparadas soluções estoque de padrão interno e das substâncias de referência em balões volumétricos de $10 \mathrm{~mL}$ como apresentadas na Tabela 3.3. $\mathrm{O}$ volume foi ajustado com $\mathrm{n}$-hexano. $\mathrm{O}$ padrão de tricaprina foi utilizado como padrão interno e, monoleína, dioleína e trioleína foram usadas como substâncias de referência para mono, di e triglicerídeos. Posteriormente foi montada a curva analítica usada para quantificação dos acilgliceróis com as 5 soluções descritas na 
Tabela 3.4 adicionando-se no final aproximadamente $8 \mathrm{~mL}$ de $\mathrm{n}$-heptano. As soluções foram analisadas em triplicata seguindo as condições cromatográficas do método desenvolvido.

Tabela 3.3 - Tabela de soluções estoque.

Composto da Solução Estoque

Monoleína (1-Mono [cis-9-octadecenoil]-rac-

glicerol)

Dioleína (1,2 - Di [cis-octadecenoil]glicerol)

Trioleína $(1,2,3$ - Tri [cis-

octadecenoil]glicerol)

Tricaprina $(1,2,3$ - tridecanolilglicerol)
50

50

Massa (mg)

50

80

Tabela 3.4 - Tabela de diluições das soluções padrão da curva analítica para quantificação de mono, di e triglicerídeos.

$\begin{aligned} & \text { Soluções } \\ & \text { estoque }\end{aligned}$
Volumes de soluções estoque (uL)

\begin{tabular}{|c|c|c|c|c|c|c|}
\hline & Níveis da Curva & 1 & 2 & 3 & 4 & 5 \\
\hline Monoleína & & 20 & 50 & 100 & 150 & 200 \\
\hline Dioleína & & 10 & 20 & 40 & 70 & 100 \\
\hline Trioleína & & 10 & 20 & 40 & 70 & 100 \\
\hline Tricaprina & & 100 & 100 & 100 & 100 & 100 \\
\hline
\end{tabular}




\subsubsection{Precisão}

A precisão do método foi avaliada devido às modificações ocorridas na programação de temperatura, forma de injeção e preparo das amostras para amostras de biodiesel metílico e etílico de óleo de soja. Sua avaliação foi realizada com os cinco níveis de calibração por meio da contaminação da amostra com os padrões. As injeções foram realizadas em triplicata. Esse procedimento também foi efetuado em diferentes dias e por diferentes analistas para a avaliação da precisão intermediária. A precisão foi expressa por meio do desvio padrão relativo.

\subsection{Aplicações}

Amostras de biodiesel de diferentes fontes apresentam também diferentes ésteres e se a reação não for completa apresenta mono, di e triglicerídeos, por isso amostras de biodiesel comercial metílico de óleo de milho e palma foram testadas visando provar a aplicação do método a diversas amostras de biodiesel. Foram preparadas soluções na concentração de $1,0 \mathrm{mg} \mathrm{mL}^{-1} \mathrm{em} \mathrm{n}$-hexano das amostras. Todas as análises foram realizadas em triplicata e calculado o valor da média das medidas e o desvio padrão.

\section{Resultados e Discussão}

Para confirmação da taxa de conversão e a ausência de glicerídeos nas amostras de biodiesel foi utilizado mistura padrão de referência contendo mono, di e triglicerídeos para obter o tempo de retenção dos possíveis interferentes. (Figura 3.1). Em seguida foram injetadas amostras de biodiesel produzidas no laboratório, representada pelo cromatograma da Figura 3.2, que demonstra um biodiesel metílico do óleo de soja.

Utilizou-se o método de introdução de amostras no modo splitless por meio minuto, apesar das normas indicarem o uso de método de injeção on-column para colunas capilares de reduzido diâmetro interno é requerido o uso de uma précoluna com diâmetro interno maior (aproximadamente $0,53 \mathrm{~mm}$ ), para que 0 excesso de amostra introduzido não sobrecarregue a coluna analítica, sendo isto uma desvantagem do método. Por isso os método de introdução de amostras "splitless" foi utilizado neste trabalho com o objetivo de obter uma metodologia de análise mais vantajosa.

Procurando-se uma programação visando maior ganho de eficiência, de acordo com as rampas testadas, obteve-se como uma melhor programação para a 
análise simultânea de ésteres, mono, di e triglicerídeos a programação indicada na Tabela 3.5.

Figura 3.1 - Cromatograma de mistura $\left(0,5 \mathrm{mg} \mathrm{mL}^{-1}\right.$ em n-hexano) contendo monoglicerídeos (MAGs), diglicerídeos (DAGs) e triglicerídeos (TAGs). Na figura é indicado também a banda de tempo de retenção dos ésteres metílicos de ácidos graxos (FAMEs). $T_{50}$ são os triglicerídeos com 50 átomos de carbono (excluindo os carbonos da cadeia de glicerol), $T_{52}$ são os triglicerídeos com 52 átomos de carbono na cadeia, $T_{54}$ triglicerídeos com 54 átomos de carbono na cadeia e $T_{56}$ triglicerídeos com 56 átomos de carbono na cadeia.

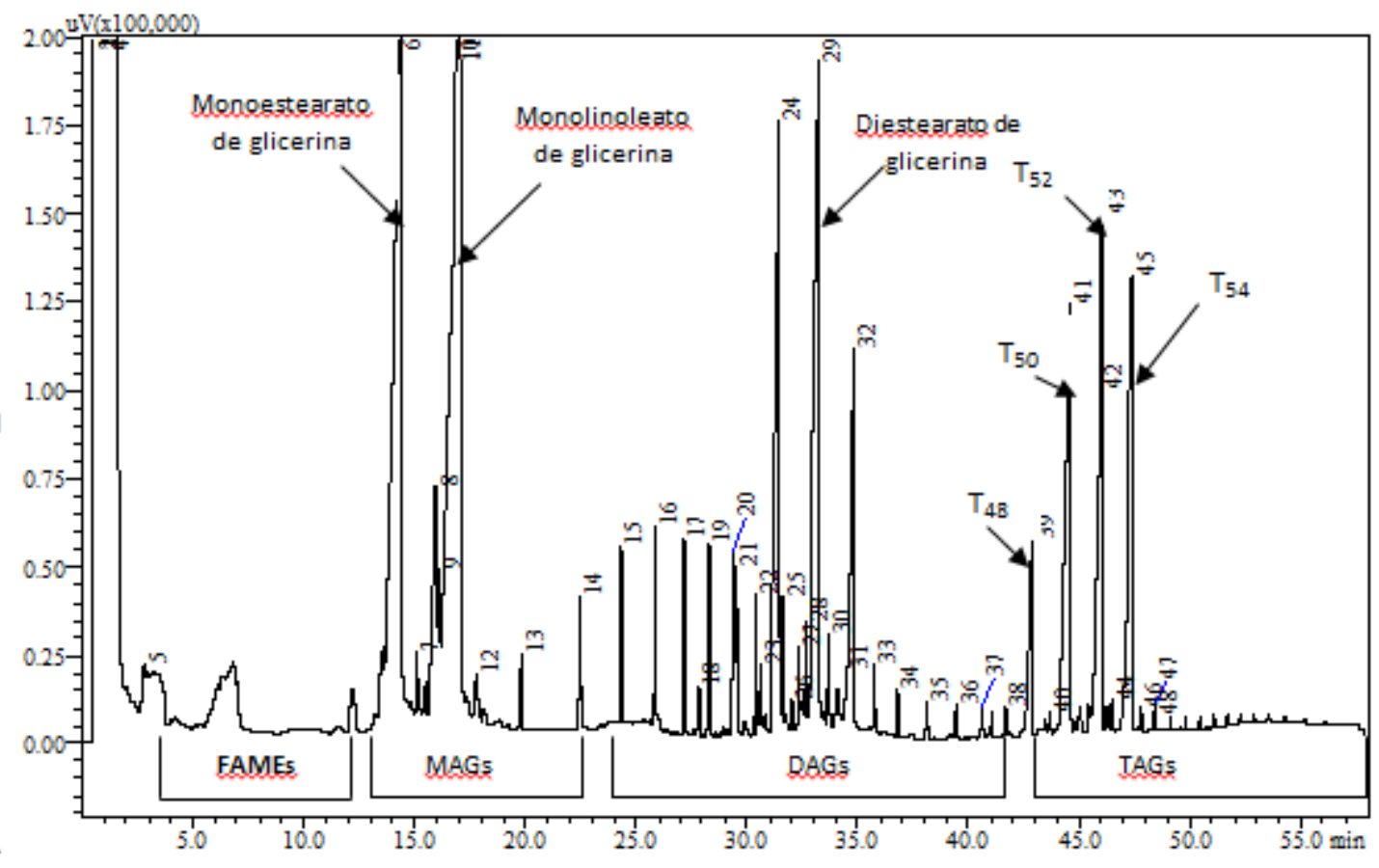

Para certificar que a melhor rampa de temperatura pode ser utilizada para qualquer tipo de amostra de biodiesel, foi adicionado uma alíquota de mistura de padrão contendo os glicerídeos em uma amostra de biodiesel metílico de soja. O cromatograma obtido é mostrado na Figura 3.3. Neste cromatograma, é possível observar que a ordem de eluição de mono, di e triglicerídeos está relacionada ao número de carbonos. Assim, aqueles com o mesmo número de carbonos, mas saturados ou insaturados são tecnicamente separados sendo que os insaturados eluem primeiro. A banda de retenção para a identificação e quantificação dos ésteres na amostra de biodiesel foi estabelecida de 15 a 30 minutos, monoglicerídeos foi de 35 a 42 minutos, para os diglicerídeos de 45 a 55 minutos e para os triglicerídeos de 57 a 75 minutos. 
Figura 3.2 - Cromatograma do biodiesel metílico de soja.

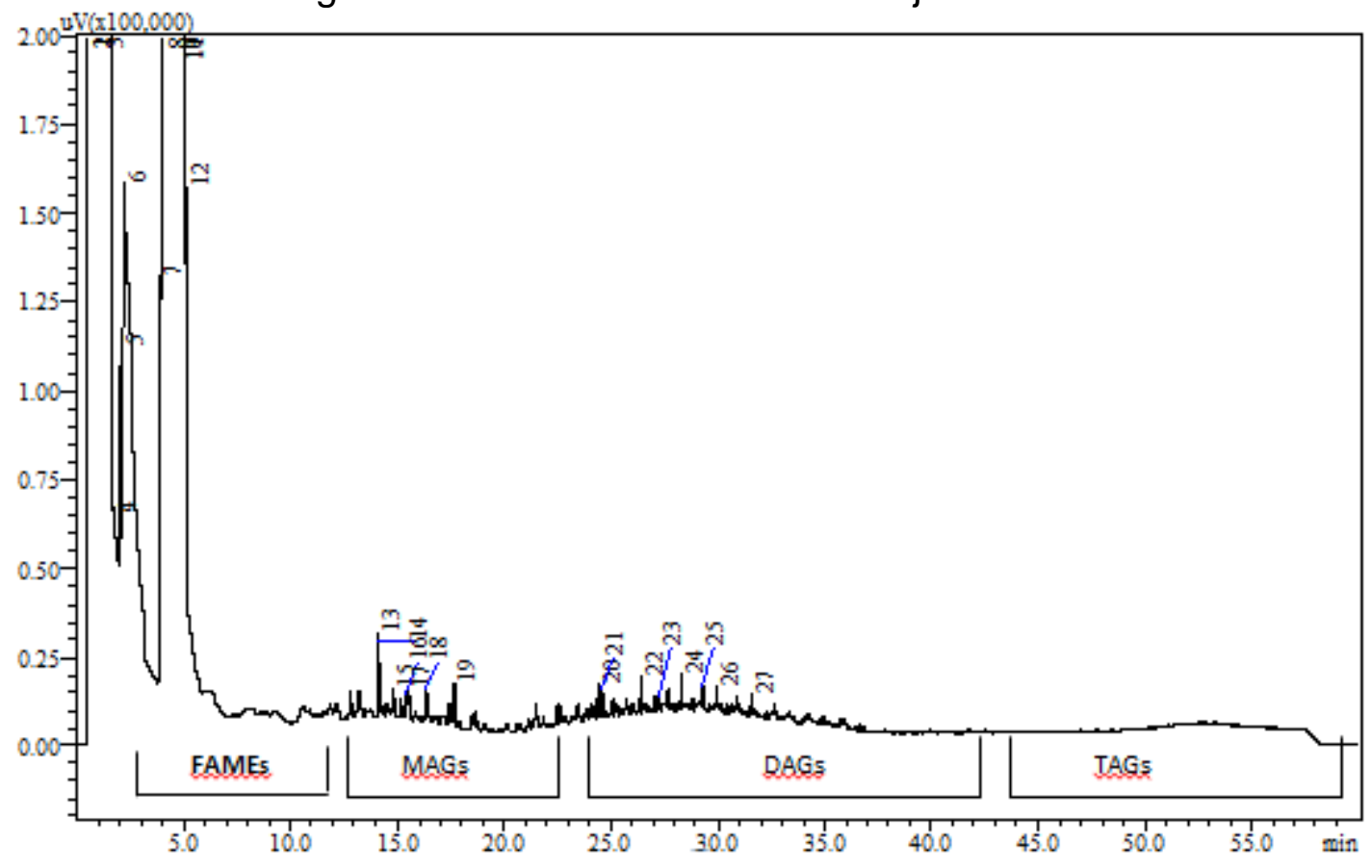

Tabela 3.5 - Tabela de programação de temperatura otimizada para análise de ésteres, mono, di e triglicerídeos em amostras de biodiesel.

\section{Programação de Temperatura da coluna}

Temperatura Inicial

Rampa 1

Rampa 2

Rampa 3
$50{ }^{\circ} \mathrm{C}$

$7^{\circ} \mathrm{C} / \mathrm{min}$ até $200 \stackrel{\circ}{\mathrm{C}}$

$5^{\circ} \mathrm{C} / \mathrm{min}$ até $297^{\circ} \mathrm{C}$

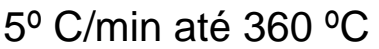

Permanência de 3 min.

Permanência de 5 min.

Permanência de 2 min.

Permanência de 15 $\min$.

O método proposto permitiu obter curva analítica para a quantificação de mono, di e triglicerídeos com boa repetibilidade para todos os níveis de calibração que apresentou coeficiente de determinação maior que 0,997 para todos os compostos, resultando em excelente linearidade. Todas as medidas de precisão obtidas mostraram desvio padrão relativo abaixo de $10 \%$. Um exemplo disto pode ser viso na Figura 3.3, que mostra como o método proposto separa eficientemente todos os mono, di e triglicerídeos, sem coeluições além de separar os ésteres dos 
demais compostos. Pelas características analíticas demostradas pelo método proposto, este foi escolhido para controle de qualidade do biodiesel.

Figura 3.3 - Cromatograma do biodiesel de soja fortificado utilizando a programação de temperatura de forno da tabela 3.5.

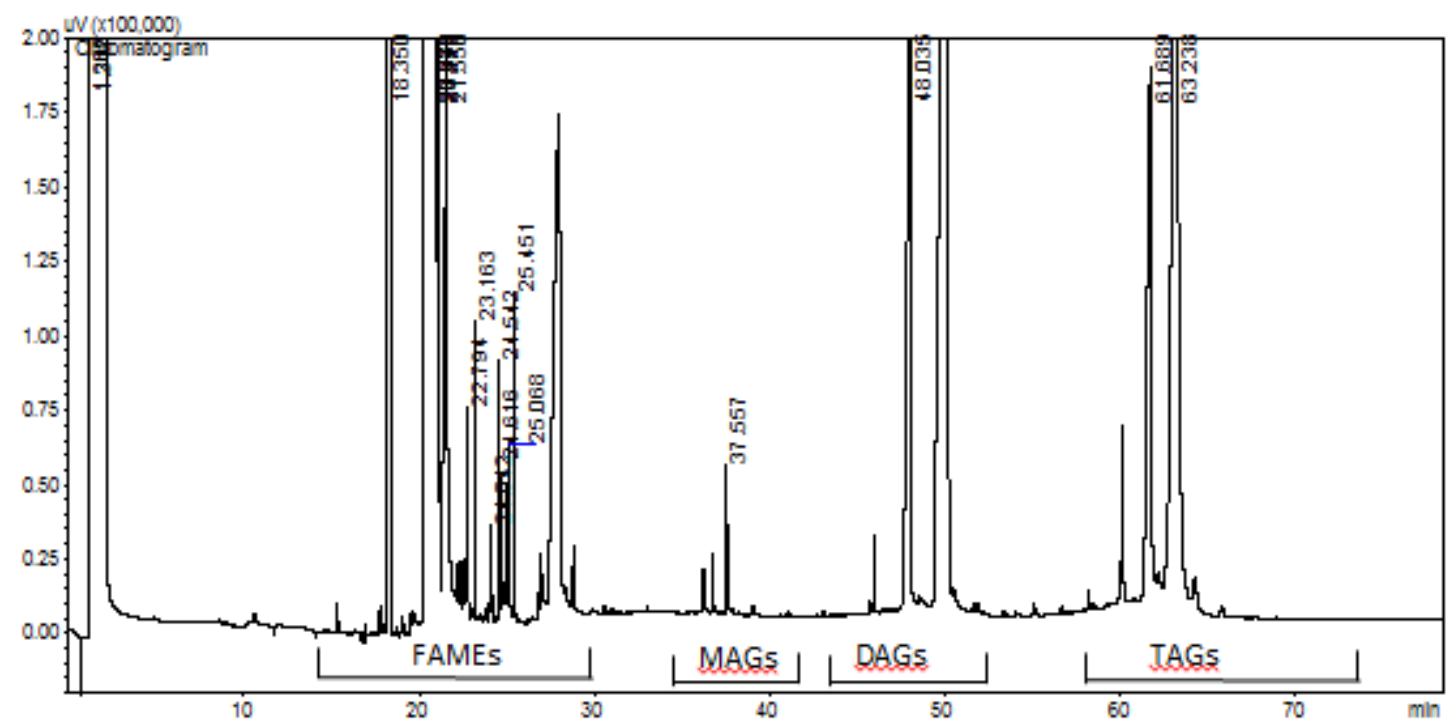

Para o cálculo da percentual $(\mathrm{m} / \mathrm{m})$ da quantidade de mono, di e triglicerídeos presente nas amostras de biodiesel foi utilizado a Equação sugerida pelo método ASTM D6584 que é mostrado na Equação 1.

$$
G=\left[a\left(\frac{A_{g}}{A_{p i}}\right)+b\right] M_{p i}\left(\frac{100}{m}\right)
$$

Equação 1

Onde $\mathrm{G}$ é o conteúdo em percentagem $(\mathrm{m} / \mathrm{m})$ dos glicerídeos individuais na amostra de biodiesel; $\mathrm{Ag}$ a área do pico dos glicerídeos individuais; Api a área do pico do padrão interno Mpi a massa do padrão interno em $\mathrm{mg}$; $\mathrm{m}$ a massa da amostra em mg; a a inclinação (coeficiente angular) da função de calibração dos mono, di e triglicerídeos e $b$ é o intercepto (coeficiente linear) da função de calibração dos mono, di e triglicerídeos. 
O método proposto consegue separar os monoglicerídeos e diglicerídeos dos ésteres de cadeia longa, evitando assim maiores ou menores estimativas nas análises quantitativas. O método proposto foi aplicado com sucesso para análises de biodíeseis de soja com catálise básica metílica e etílica além de análises de biodiesel de milho e palma. Portanto, ótimos resultados foram encontrados, demonstrando que seu objetivo, ou seja, a otimização de metodologia analítica para determinação de óleos e seus derivados, foi atingida.

\section{Conclusões}

Para introdução de novos combustíveis automotivos na matriz energética é preciso estabelecer padrões de qualidade de forma garantir a segurança do consumidor, salvaguardar o motor e avalizar a qualidade das emissões da queima. Estes parâmetros estão associados a características químicas do combustível, que podem ser avaliadas através de métodos físico-químicos de análise. Desta forma, procura-se conquistar a confiança do mercado e da indústria automotiva, garantindo o sucesso do novo combustível.

Um grande número de estudos sobre reações de transesterificação com diferentes óleos vegetais pode ser encontrado na literatura, porém, poucos esforços têm sido feitos no sentido de identificar subprodutos como mono, di e triglicerídeos nas amostras de biodiesel, sendo, também possível a aplicação desta metodologia para detecção de fraudes.

Com o aumento da eficiência de separação obtido com as modificações instrumentais e que resultam em maior resolução cromatográfica foi possível a determinação dos subprodutos da reação de transesterificação. Os resultados obtidos neste trabalho permitem, assim, concluir que a técnica HRGC empregando o método proposto corresponde a uma excelente alternativa para realizar a determinação de mono, di e triglicerídeos em controle de qualidade de biodiesel metílico e etílico do óleo de soja além de palma e milho.

Os resultados obtidos nesta parte do trabalho abrem a perspectiva de futura implementação deste método, extensivamente a biodiesel proveniente de outras matrizes.

Este estudo pode ser estendido tanto para os ésteres metílicos quanto para os ésteres etílicos de ácidos graxos. Portanto, resultados facilmente 
interpretados que poderão ser utilizados por profissionais das diferentes áreas sem maiores dificuldades foram obtidos.

\section{Sugestões para trabalhos futuros}

Diante dos resultados encontrados, sugere-se para trabalhos futuros os seguintes temas:

- Análise de componentes do biodiesel envolvendo diferentes colunas cromatográficas, com estudo simultâneo do diâmetro interno, comprimento e espessura do filme.

\section{Referências}

1 SHARMA, Y. C.; SINGH, B.; UPADHYAY, S. N. Advancements in development and characterization of biodiesel. Fuel, v. 87, n. 12, p. 2355-2373, 2008.

2 KNOTHE, G. Dependence of biodiesel fuel properties on the structure of fatty alkyl esters. Fuel Processing Technology, v. 86, n. 10, p. 1059-1070, 2005.

3 disponível em http://nxt.anp.gov.br/NXT/gateway.dll/leg/leis/2005/lei\%2011.097\%20\%202005.xml?f $=$ templates $\$ f n=$ default.htm\&sync=1\&vid=anp:10.1048/enu) acessada em junho 2013.

4 CHRISTIE, W. W. Gas chromatography and lipids: a practical guide. Ayr: The Oily Press, 1989. 307 p.

5 MORETTO, E.; FETT, R. Tecnologia de óleos e gorduras vegetais. São Paulo: Varela, 1998. $150 \mathrm{p}$.

6 MEHER, L. C.; SAGA, D.V.; NAIK, S.N. Technical aspects of biodiesel production by transesterification - a review. Renewable and Sustainable Energy Reviews, V. 10, n. 3, p. 248-268, 2006.

7 RIBANI, M.; BOTTOLI, C. B.G.; COLLINS, C.H.; JARDIM, I. C. S. F.; MELLO, L.F.C. Validação em métodos cromatográficos e eletroforéticos. Química Nova, v. 27, n. 5, p. 771-780, 2005. 


\section{CONCLUSÃO GERAL}

"The most exciting frase to hear in science, the one that heralds new discoveries, is not 'Eureka!' but 'hum.... that's funny ..." 
Este trabalho teve por foco o estudo da produção de biodiesel etílico supercrítico, em batelada, envolvendo os efeitos de variáveis de processo, além do aperfeiçoamento dos métodos cromatográficos de análise dos produtos e subprodutos do biodiesel.

Em relação ao aparato experimental montado para condução das reações, os resultados obtidos nos estimularam a utilizar e recomendar este modelo de sistema para a produção de biodiesel utilizando etanol supercrítico e para o estudo de futuras investigações envolvendo distintos álcoois.

Por meio da investigação das variáveis do processo pode-se concluir que a obtenção do biodiesel a partir do óleo de soja adotado neste trabalho produziu uma conversão de até $98 \%$ do óleo em ésteres metílicos e etílicos. O biodiesel produzido apresentou-se também com qualidade de acordo com os parâmetros estabelecidos pela ANP com relação ao teor de ésteres.

Uma metodologia para a determinação de acilgliceróis em amostras de biodiesel também foi desenvolvida, a qual foi aplicada na análise de biodiesel oriundo de óleo de soja. Como perspectiva, a metodologia pode ser ampliada para a análise de amostras de biodiesel produzido a partir de outros óleos vegetais de interesse nacional.

Os critérios de desempenho avaliados foram linearidade, exatidão e precisão sendo que o método mostrou-se adequado. No presente estudo, o desvio padrão relativo manteve-se sempre inferior a $10 \%$ em toda a faixa de trabalho para os analistas A e B e entre dias, indicando uma boa precisão dos resultados. O método desenvolvido também apresentou boa linearidade e repetibilidade, podendo ser utilizado na determinação qualitativa e quantitativa da composição do biodiesel usado. Os resultados também indicam boa capacidade de pico e melhor resolução cromatográfica do método desenvolvido quando comparado com os descritos na literatura consultada para amostras de biodiesel de soja, milho e palma fortificados. 